Universidade de São Paulo

Faculdade de Medicina de Ribeirão Preto

Departamento de Genética

\title{
CNVS EM PACIENTES COM LÚPUS ERITEMATOSO SISTÊMICO
}

\section{FERNANDA BUENo BARBosa}

Orientador: Prof. Dr. Aguinaldo Luiz Simões 
Universidade de São Paulo

Faculdade de Medicina de Ribeirão Preto

Departamento de Genética

\section{CNVS EM PACIENTES COM LÚPUS ERITEMATOSO SISTÊMICO}

\section{FERNANDA BUENo BARBosa}

Dissertação apresentada à Faculdade de Medicina de Ribeirão Preto da Universidade de São Paulo, como requisito parcial para a obtenção do título de Mestre em Ciências, área de concentração: Genética

\section{Versão corrigida}

A versão original encontra-se disponível na secretaria do Programa de Pós-Graduação em Genética/FMRP

Orientador: Prof. Dr. Aguinaldo Luiz Simões

Ribeirão Preto

2013 


\begin{abstract}
AUTORIZO A REPRODUÇÃO E DIVULGAÇÃO TOTAL OU PARCIAL DESTE TRABALHO, POR QUALQUER MEIO CONVENCIONAL OU ELETRÔNICO, PARA FINS DE ESTUDO E PESQUISA, DESDE QUE CITADA A FONTE.
\end{abstract}

\title{
Ficha CATALOGRÁficA
}

Barbosa, Fernanda Bueno.

CNVs em pacientes com Lúpus Eritematoso Sistêmico/ Fernanda Bueno Barbosa; orientador Aguinaldo Luiz Simões. - Ribeirão Preto, 2013.

127 f. il. $30 \mathrm{~cm}$.

Dissertação (Mestrado - Programa de Pós-Graduação em Genética.) Faculdade de Medicina de Ribeirão Preto da Universidade de São Paulo.

1. Variação no número de cópias; 2. LES; 3. Hibridação Genômica em arrays; 4. GeneChip; 5. Variabilidade genética. 


\section{FOLHA DE APROVAÇÃo}

FERNANDA BUENO BARBOSA

CNVS EM PACIENTES COM LÚPUS ERITEMATOSO SISTÊMICO

Dissertação apresentada à Faculdade de Medicina de Ribeirão Preto da Universidade de São Paulo, como requisito parcial para a obtenção do título de Mestre em Ciências, área de concentração: Genética

APROVADO EM:

BANCA EXAMINADORA

Prof. Dr.

Instituição: Assinatura:

Prof. Dr.

Instituição:

Assinatura:

Prof. Dr.

Instituição: Assinatura: 
Dedico esta dissertação a duas pessoas, Roberto e Regina, que em nenhum momento mediram esforços para realização dos meus sonhos, que me guiaram pelos caminhos corretos, me mostraram que a honestidade e o respeito são essenciais à vida, e que devemos sempre lutar pelos nossos objetivos. Tenho muito orgulho por chamá-los de pai e mãe. 


\section{Agradecimentos}

À Deus, que me iluminou e me deu forças durante toda a trajetória.

Aos meus pais Roberto e Regina, e irmãos Roberto, Gabriel e João Eduardo pela compreensão, apoio, e respeito as minhas ausências. Obrigada pelo incentivo, pela confiança e amor.

Ao orientador Prof. Dr. Aguinaldo Luiz Simões, o meu reconhecimento e gratidão pelos ensinamentos ao longo desses dois anos, pelo incentivo e confiança a mim depositada.

À Prof ${ }^{a} \operatorname{Dr}^{\mathrm{a}}$ Milena Simioni. A sua participação foi imprescindível para a realização deste trabalho. Muito obrigada por sempre acreditar que iria dar certo, pela ajuda, pela prontidão e disponibilidade.

À Prof ${ }^{a}$ Dr $^{a}$ Vera Lúcia Lopes pela oportunidade de colaboração com o seu grupo de pesquisa, pela receptividade em seu laboratório e gentileza.

Ao Prof. Dr. Eduardo Donadi por ter gentilmente cedido as amostras e a todos os pacientes voluntários, sem os quais esta pesquisa não poderia ter sido realizada.

À banca examinadora pela disposição em participar na contribuição para o crescimento deste trabalho.

Ao Julian, pelo companheirismo, compreensão, paciência e amor. Obrigada pelo apoio incondicional.

Às amigas Nathalia e Laís pelo convívio diário. A presença de vocês, o apoio e descontração tornaram cada momento mais agradável.

Aos colegas do Bloco B, em especial Maria, Ana Lúcia, Juliana, Flavia, Natalia, Leonardo, Nadia, Marcela, Sabrina, Cláudia Wiezel, Cláudia Caixeta, Edna e Rosana, pela prazerosa convivência, pelas sugestões, apoio e incentivo.

Às amigas de infância Amanda, Carolina, Luiza e Raíssa, e aos amigos que fiz durante a graduação Patrícia, Mariana, Lyzia, Helder, Tati, Hellen, Dani, 
Vinicius e Carol. A amizade de vocês é um presente de Deus. Obrigada pelo carinho, atenção e incentivo.

Aos meus pequenos Mylena, Branca, Eduardo, Isabela e Thaís, que fazem da minha vida uma alegria, com os seus sorrisos e gracinhas.

Ao primo-irmão Ronaldo e irmã de coração Olivia, por sempre terem me escutado, aconselhado e incentivado.

À Maria Eugênia Camargo do Laboratório de Microarranjos do CNPEM, que auxiliou na realização da técnica de $a G H$.

À Faculdade de Medicina de Ribeirão Preto/USP e Departamento de Genética pela oportunidade da realização do curso de Mestrado.

A todos os professores e funcionários do Departamento de Genética.

Ao CNPq pelo apoio financeiro.

A todos que de alguma forma, me auxiliaram, incentivaram ou proporcionaram bons momentos para a continuação e finalização deste trabalho. 
"O essencial é invisivel aos ol hos"

Le Petit Prince

(Antoine de Saint-Exupéry) 


\title{
Resumo
}

\author{
BARBOSA, F.B. CNVs em pacientes com Lúpus Eritematoso Sistêmico. \\ 2013. 127p. Dissertação de Mestrado - Faculdade de Medicina de Ribeirão \\ Preto, Universidade de São Paulo, Ribeirão Preto.
}

Palavras-chave: variação no número de cópias, LES, Hibridação Genômica em arrays de alta densidade, GeneChip, variabilidade genética.

O genoma humano varia entre os indivíduos não somente na forma de sequência, mas também estruturalmente. Originalmente, organismos diploides possuem duas cópias de cada região autossômica, uma por cromossomo. Entretanto, com o avanço das técnicas moleculares de identificação do DNA, foram descritas sequências que se repetem em diferentes regiões do genoma em número maior ou menor do que as duas cópias esperadas. Essas variantes são denominadas copy number variants (CNVs) e definidas como segmentos genômicos, geralmente maiores do que 1 kilobase $(\mathrm{kb})$, que variam em número de cópias em comparação com o genoma de referência. As CNVs podem contribuir para a variabilidade do risco entre os indivíduos na etiologia de doenças complexas. Nesse contexto, o Lúpus Eritematoso Sistêmico (LES) é uma doença autoimune com forte componente genético, caracterizada por inflamação crônica e produção de autoanticorpos. Estudos de associação genômica em larga escala (GWAS) identificaram vários loci associados ao LES que contribuem para a susceptibilidade à patogênese. Entretanto, as pesquisas atuais com CNVs e LES focalizam apenas a análise individual de algumas variantes. O objetivo do presente trabalho foi conduzir o primeiro estudo de CNVs em larga escala em pacientes com LES. A detecção de CNVs foi feita por ensaio de Hibridação Genômica em arrays, utilizando a plataforma Affymetrix GeneChip ${ }^{\circledR}$ CytoScan ${ }^{\mathrm{TM}} H D$ em amostra de 23 pacientes com LES. Foram identificadas $406 \mathrm{CNVs}$ distribuídas em todos os cromossomos, exceto no Y. A média foi de $18 \mathrm{CNVs}$ por paciente. As deleções foram mais frequentes do que as duplicações, 311 e 95, respectivamente. O perfil de CNVs revelou 269 CNVs envolvendo genes, 152 CNVs únicas e 59 regiões de CNVs (CNVRs). Nove CNVs identificadas não haviam sido descritas em bancos de dados de variantes estruturais. Adicionalmente, encontramos CNVs em cinco genes previamente associados com LES: CFHR4, CFHR5, STAT4, MECP2 e HLA-DPB2. CNVs nestes genes foram reportadas em pacientes com LES pela primeira vez. O conhecimento das CNVS associadas com LES e autoimunidade podem contribuir para o entendimento da etiologia da doença. Em conclusão, o presente estudo foi o primeiro delineamento em larga escala de CNVs do genoma completo em pacientes com LES. 


\section{Abstract}

BARBOSA, F.B. CNVs in Systemic Lupus Erythematosus Patients. 2013. 127p. Master's Dissertation - Faculty of Medicine of Ribeirão Preto, University of São Paulo, Ribeirão Preto.

Keywords: copy number variation, SLE, high-resolution array Genomic Hybridization, GeneChip, genomic variability.

The human genome varies between individuals not only at the sequence level but also structurally. Originally, diploid organisms have two copies of each autosomal region, one per chromosome. Advances in molecular-based techniques for DNA identification enabled the description of many repeated sequences with higher or lower copy number than that two copies expected. Those sequences are termed copy number variants (CNVs) and are defined as genomic segments, usually greater than 1 kilobase $(\mathrm{kb})$ in size, ranging in copy number when compared to reference genome. CNVs can contribute to risk variability among individuals in complex diseases etiology. In this context, Systemic Lupus Erythematosus (SLE) is an autoimmune disease with strong genetic component and is characterized by chronic inflammation and autoantibodies production. To date, genome-wide association studies (GWAS) have identified several loci associated with SLE that contribute to pathogenesis susceptibility. However, current CNVs studies associated with SLE focus only in few variants analysis. The aim of the present study was to conduct the first genome-wide CNVs study in SLE patients. CNVs detection was performed by high-resolution array Genomic Hybridization Assay, using the Affymetrix GeneChip ${ }^{\circledR}$ CytoScan ${ }^{\mathrm{TM}} H D$ platform, in 23 SLE patients samples. We identified $406 \mathrm{CNVs}$ distributed in all chromosomes, except Y. The average was 18 CNVs per patient. Deletions were more frequent than duplications, 311 and 95, respectively. CNV profile showed 269 CNVs overlapped by genes, 152 unique CNVs and $59 \mathrm{CNV}$ regions (CNVRs). Nine CNVs were never described in structural variants databases. We found CNVs in five genes previously associated with SLE: CFHR4, CFHR5, STAT4, MECP2 and HLA-DPB2. CNVs in these genes were reported in SLE patients for the first time. Knowledge of CNVs associated with SLE risk and autoimmunity could also improve our understanding of disease etiology. In conclusion, the present study was the first effort to search for CNVs in whole genome of SLE patients. 


\section{Lista de Tabelas}

Tabela 1. Frequência das manifestações clínicas no Lúpus Eritematoso Sistêmico 23

Tabela 2. Critérios do American College of Rheumatology para o diagnóstico de LES.

Tabela 3. Parâmetros de qualidade dos experimentos de $a G H$. .54

Tabela 4. Distribuição de CNVs nos pacientes com LES. 55

Tabela 5. Distribuição das faixas de tamanho das CNVs encontradas nos pacientes. 56

Tabela 6. Grandes $C N V s(>450 \mathrm{~kb})$ identificadas na amostra de pacientes com LES.

Tabela 7. Recorrência das CNVs por cromossomo .59

Tabela 8. CNVRs encontradas nos pacientes com LES. 60

Tabela 9. Distribuição geral das CNVs que possuem genes nos pacientes com LES.

Tabela 10. CNVs com genes descritos no OMIM. 66

Tabela 11. $C N V$ s não descritas no $D G V$. 68

Tabela 12. CNVs não descritas em banco de dados. .69

Tabela 13. CNVs em genes relacionados com autoimunidade. 71

Tabela 14. CNVs comuns presentes no conjunto amostral. 72

Tabela 15. Proporção variável do genoma representada pelas CNVs nos pacientes com LES. .76 


\section{Lista de Figuras}

Figura 1. Genótipos possiveis quando há variação do número de cópias.... 16

Figura 2. Paralelo entre as descobertas genéticas e a determinação de genes em associação com LES.

Figura 3. Padrão de bandas do gel de agarose $2 \%$ dos produtos amplificados da PCR

Figura 4. Padrão de bandas do gel de agarose $4 \%$ dos produtos fragmentados.

Figura 5. Representação de uma região de $C N V$.

Figura 6. Gráfico mostrando a distribuição de tamanhos das CNVs nas amostras de LES.

Figura 7. Distribuição das $C N V$ s encontradas por cromossomo. 58

Figura 8. Distribuição do total de $C N V s$ comparado àquelas que possuem genes nos pacientes com LES. 63

Figura 9. Localização genômica das $C N V$ s não descritas em banco de dados. 70

Figura 10. Localização genômica das CNVs relacionadas com autoimunidade. .71

Figura 11. Processos biológicos dos genes envolvidos com autoimunidade presentes nas CNVs encontradas nos pacientes com LES (PANTHER Classification System). .73 


\section{Sumário}

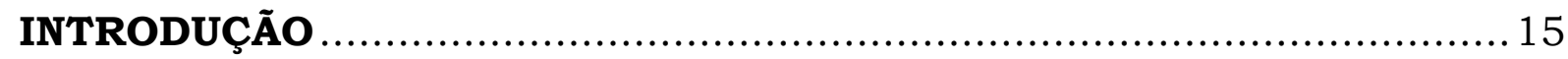

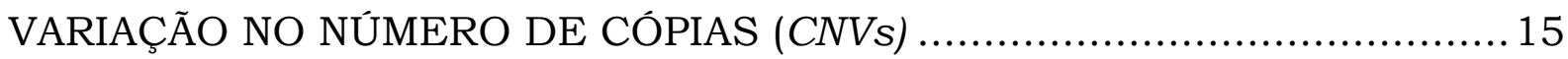

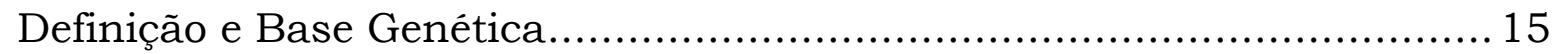

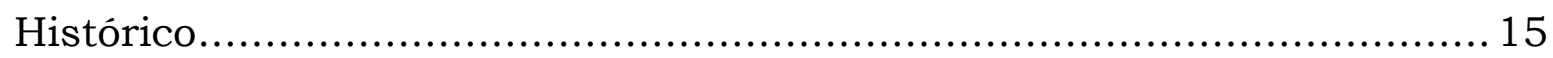

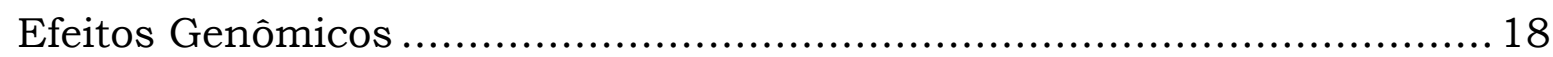

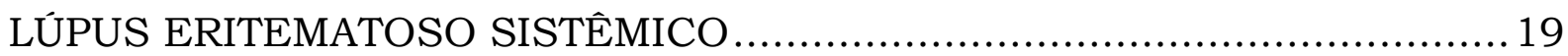

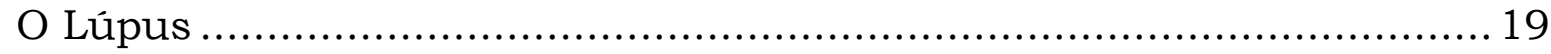

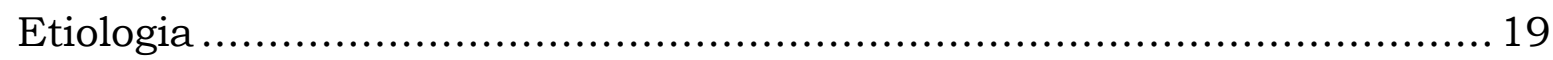

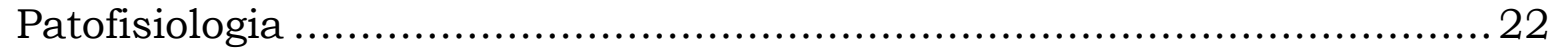

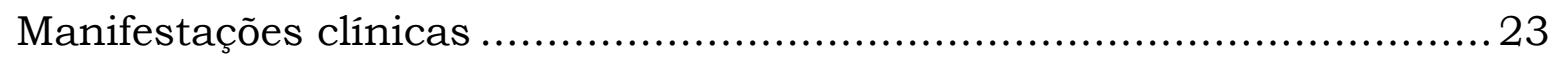

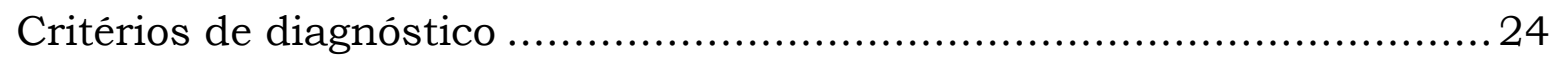

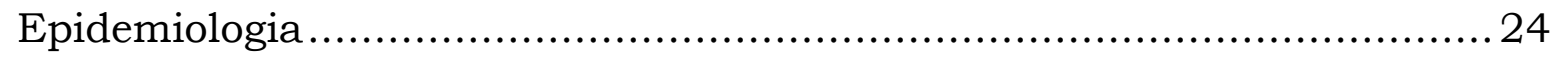

BASE GENÉTICA DO LÚPUS ERITEMATOSO SISTÊMICO ….................25

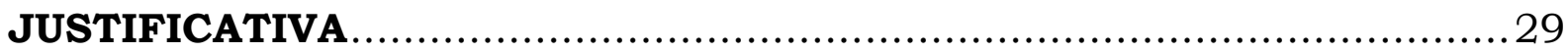

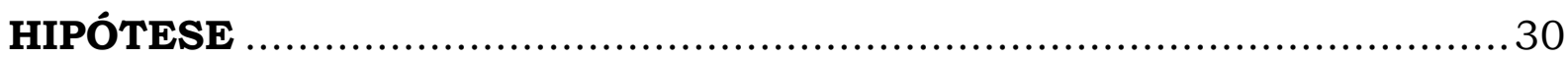

OBJETIVOS

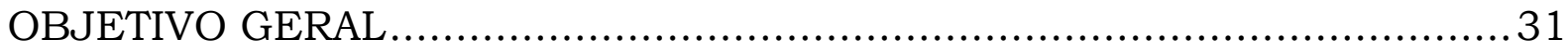

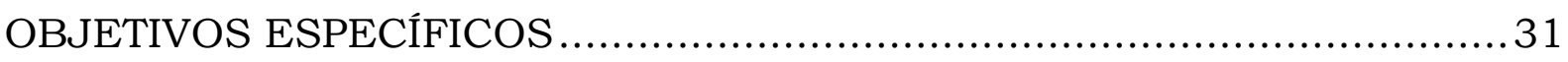

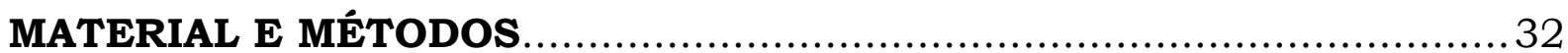

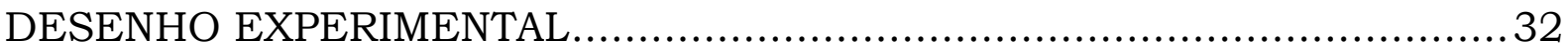

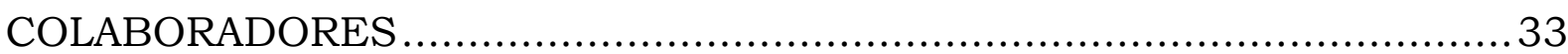

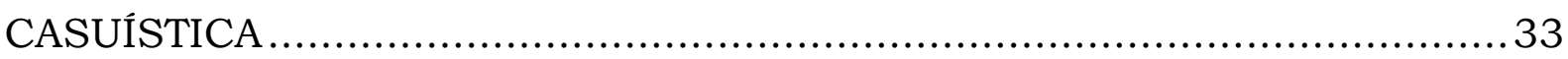

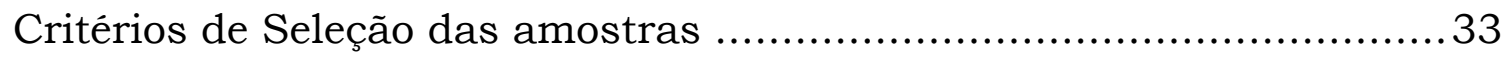

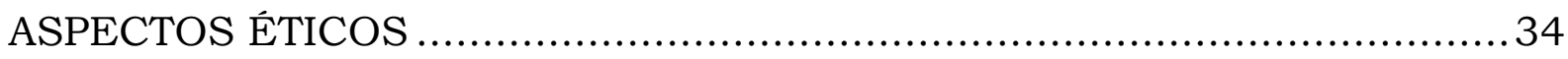

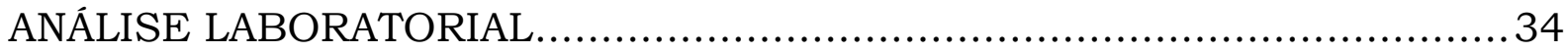

Extração do DNA das amostras de pacientes........................................34

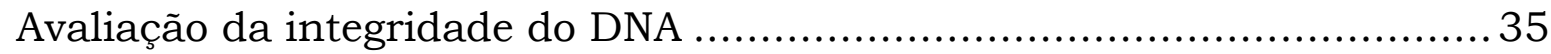

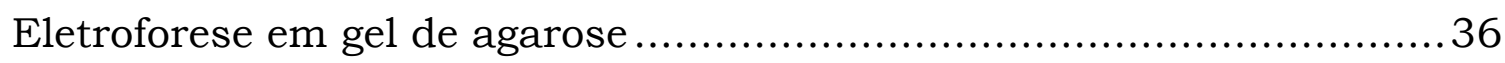

Quantificação e Diluição das amostras .............................................36

Detecção de CNVs: Hibridação Genômica em arrays ............................. 37

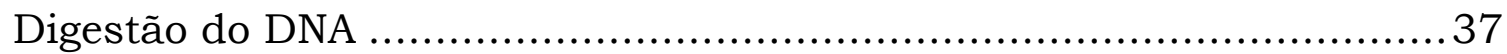

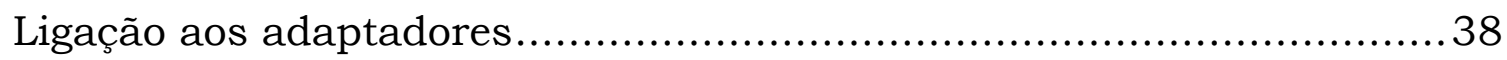

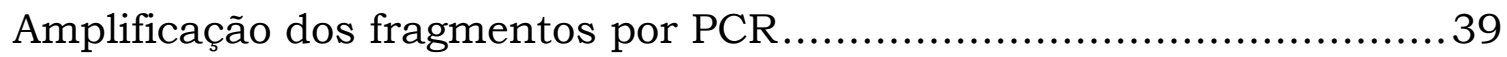

Purificação dos produtos da PCR .................................................4 41

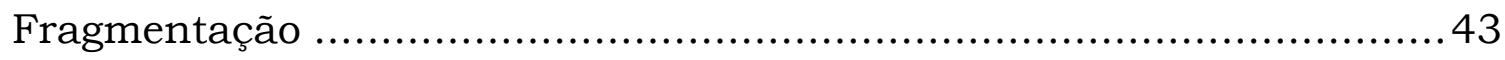




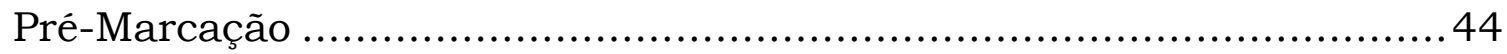

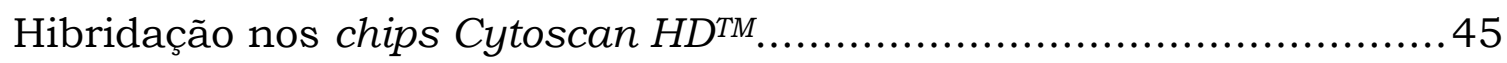

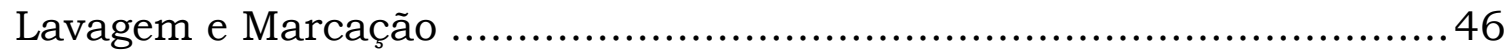

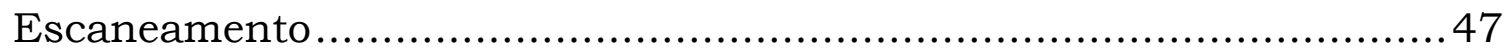

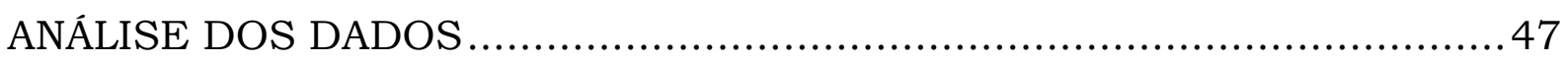

Determinação de CNVs pelo software ChAS ....................................... 47

Modelo de referência de populações do projeto HapMap ........................48

Padrões de qualidade dos experimentos ......................................... 48

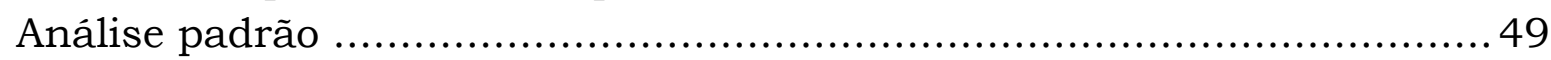

Avaliação das $C N V$ s descritas em bancos de dados .............................50

Determinação do padrão de recorrência das $C N V s$............................. 51

Análise de regiões específicas: cytoregions.......................................... 51

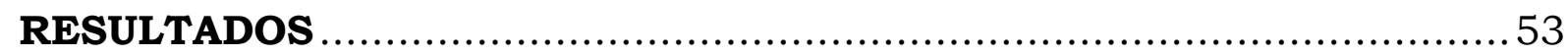

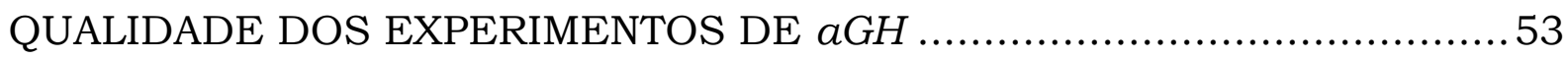

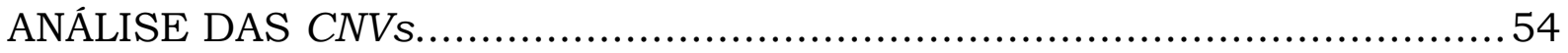

Distribuição das CNVs na amostra de pacientes com LES .................... 54

Distribuição de tamanho das CNVs identificadas ................................ 55

Distribuição de CNVs nos cromossomos ...................................... 58

Padrão de recorrência das $C N V s$.................................................... 58

Distribuição geral das CNVs envolvendo genes..................................6 63

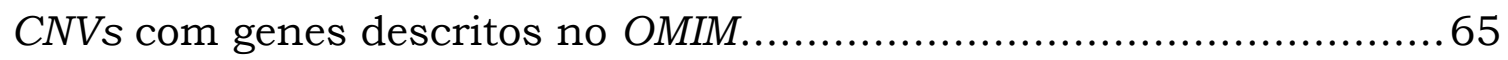

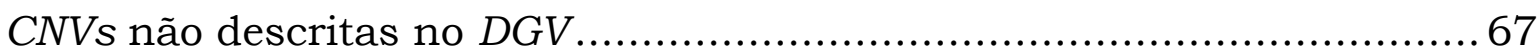

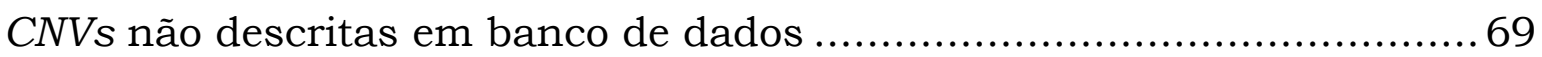

CNVs em genes relacionados com autoimunidade ............................... 70

CNVs comuns em genes relacionados com autoimunidade..................72

DISCUSSÃO

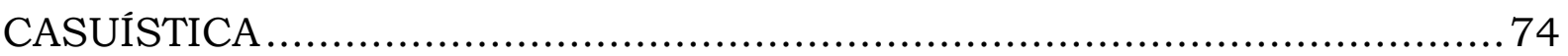

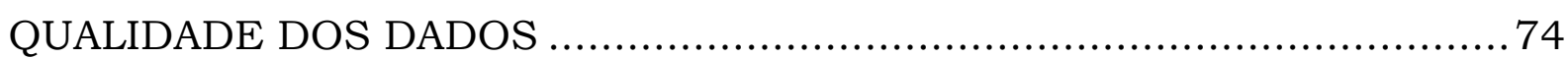

PROPORÇÃO VARIÁVEL DO GENOMA …............................................. 75

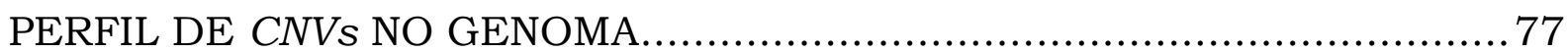

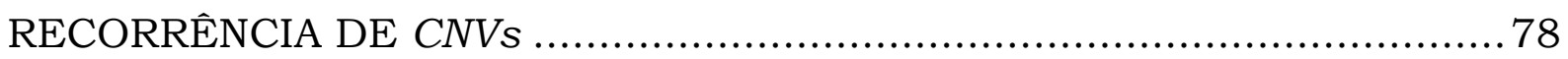

RELEVÂNCIA FUNCIONAL DAS CNVS IDENTIFICADAS .........................79

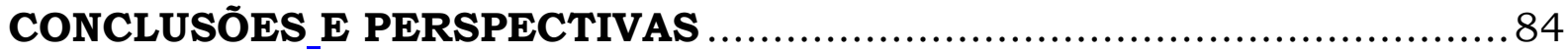

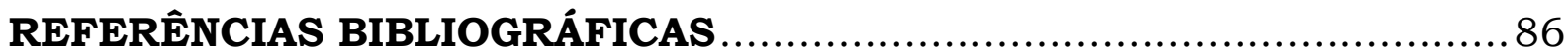

APÊNDICE 


\section{INTRODUÇÃO}

\section{VARIAÇÃO NO NÚMERO DE CÓPIAS (CNVS)}

\section{DEFINIÇÃO E BASE GENÉTICA}

O genoma humano varia entre os indivíduos não somente na forma de sequência, representado pelos polimorfismos de nucleotídeo único (SNPS), mas também estruturalmente (STANKIEWICZ, P.; LUPSKI, 2010). Organismos diploides possuem duas cópias de cada região autossômica, uma em cada cromossomo homólogo. Entretanto, duplicações e deleções podem resultar em alterações no número diploide de cópias dos segmentos no genoma (CHOY et al., 2010). Com o avanço das técnicas moleculares de identificação e análise do DNA, foram descritas sequências que se repetem em diversas regiões do genoma em número diferente das duas cópias esperadas (ISKOW; GOKCUMEN; LEE, 2012). Essas variantes são denominadas Copy Number Variations (CNVs) e definidas como segmentos genômicos, geralmente maiores do que 1 kilobase $(\mathrm{kb})$, que variam em número de cópias em comparação com o genoma de referência (ALKAN; COE; EICHLER, 2011) (Figura 1). Esta forma de variação é análoga aos micro e minissatélites, que consistem em unidades repetitivas curtas (2-4 nucleotídeos e 10-100 nucleotídeos, respectivamente), entretanto, o termo $C N V$ refere-se a grandes regiões repetidas que incluem centenas de nucleotídeos (WAIN; TOBIN, 2011).

A estrutura de uma $C N V$ é caracterizada por ganhos ou perdas de sequências homólogas em múltiplos locais no genoma, e pode envolver tanto duplicações de segmentos in tandem quanto translocações (REDON et al., 2006). Adicionalmente, as CNVs não possuem necessariamente genótipos dialélicos. A ocorrência de CNVs multialélicas, isto é, as que apresentam mais de um evento de duplicação e/ou deleção no mesmo locus é possível (WAIN; TOBIN, 2011). Dependendo da região genômica variável, as CNVs podem conter genes completos ou parciais (MANOLIO et al., 2009). 


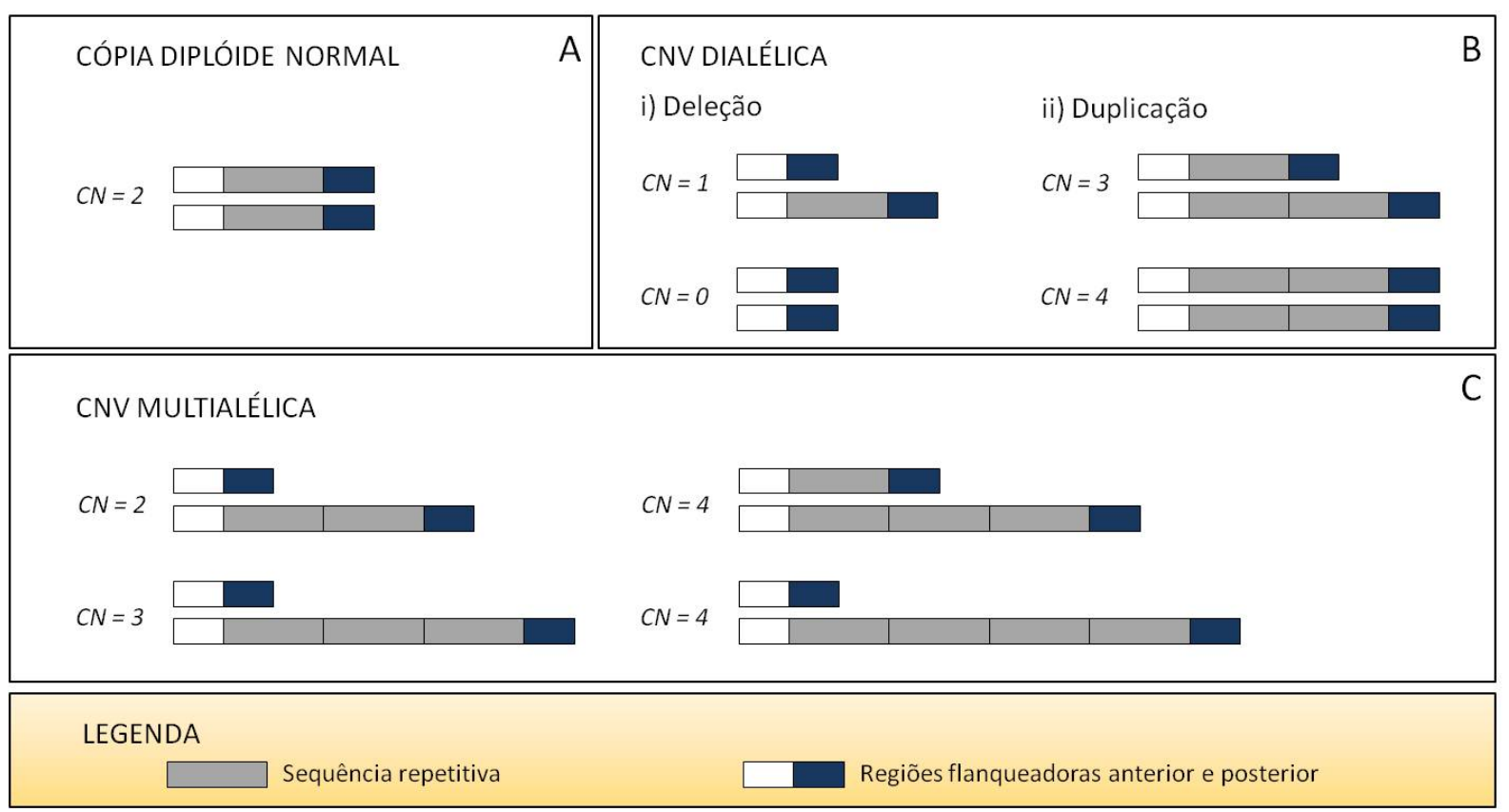

Figura 1. Genótipos possíveis quando há variação do número de cópias. A) Variação no número de cópias normal: número de cópia (CN) diplóide. B) Variação dialélica; (i) deleção heterozigótica e homozigótica resultando um número de cópias de um e zero, respectivamente; (ii) duplicação heterozigótica e homozigótica resultando um número de cópias de três e quatro, respectivamente. C) Alguns exemplos de variação multialélica em que se observa que o mesmo número de cópias pode ser obtido por diferentes combinações genotípicas (Adaptado de WAIN; TOBIN, 2011).

\section{HISTÓRICO}

O estudo de doenças que envolvem modificações no número de cópias no genoma humano é conhecido desde a década de 1970 (HE; HOSKINS; MCLEOD, 2011). Entretanto, a dimensão dessa variabilidade só se tornou evidente em 2004, quando dois trabalhos independentes (IAFRATE et al., 2004; SEBAT et al., 2004) demonstraram que individuos saudáveis apresentavam centenas de regiões genômicas que variavam no número de cópias, as CNVs. A análise do conteúdo de tais CNVs revelou que a maioria dessas regiões deletadas ou duplicadas do genoma incluía genes e que parte delas foram observadas em mais de um individuo, sugerindo caráter polimórfico (IAFRATE et al., 2004). Dessa forma, a descoberta das CNVs como fonte significativa de variabilidade forneceu evidências para uma visão mais ampliada da variação genética humana (ZHANG et al., 2009). 
Os primeiros estudos de CNVs foram baseados em Cromossomos Artificiais Bacterianos em arrays (BAC arrays) ou em plataformas de oligonucleotídeos de baixa resolução, que permitiram apenas a detecção de CNVs superiores a $100 \mathrm{~kb}$ (SEBAT, 2007). Todavia, os limites dessas alterações não foram bem definidos o suficiente para permitirem uma avaliação exata da proporção do genoma alterado. Isto levou a uma superestimação da extensão do número de cópias, que foi posteriormente refinada por ensaios de microarranjo, primordiais na descoberta e genotipagem de CNVs (CHOY et al., 2010; ITSARA et al., 2009). Estes são representados principalmente pela hibridação genômica em arrays $(a G H)$, hibridação genômica comparativa em arrays $(a \mathrm{CGH})$ e polimorfismo de nucleotídeo único em arrays (SNP array). As técnicas são baseadas em hibridação para inferir os ganhos ou perdas no número de cópias, comparados com amostras de referência ou da população, mas diferem nos detalhes e na aplicação dos testes moleculares (ALKAN et al., 2011).

As novas tecnologias desenvolvidas proporcionaram mapeamento mais preciso das CNVs (FANCIULLI et al., 2007). Em 2006, o primeiro mapa abrangente de CNVs do genoma humano foi construído (REDON et al., 2006), o que caracterizou-se como um recurso para estudos de estrutura do genoma. As observações decorrentes desse mapa e de trabalhos subsequentes (JAKOBSSON et al., 2008) evidenciaram a complexidade dessa forma de variação genômica. Os estudos atuais focam-se em triagem da extensão total da variação estrutural com o intuito de compreender seus efeitos sobre as doenças humanas, as características complexas e evolução (ALKAN et al., 2011).

Com o aumento do conhecimento sobre as CNVs, a anotação precisa destas variantes tornou-se necessária. Atualmente, bancos de dados estão disponiveis para o registro de variantes genômicas (ZHANG et al., 2009). O principal deles é o $D G V$ (Database of Genomic Variants) (IAFRATE et al., 2004) no qual estão catalogadas 610.834 CNVs até a presente data (Janeiro, 2013). 


\section{EFEITOS GENÔMICOS}

O desvio do estado diploide esperado tem consequências quando são envolvidas grandes regiões genômicas (STANKIEWICZ, P.; LUPSKI, 2010). Os transtornos genômicos, tais como sindrome de Down, síndrome de Cri du chat são exemplos de quando o ganho ou perda de cromossomos completos ou segmentos extensos tem consequências fenotípicas severas (LUPSKI, 2007).

Em um nível mais sutil, o número de cópias de varia entre indivíduos aparentemente saudáveis, o que implica um papel contributivo das CNVs na variação humana normal (INGELMAN-SUNDBERG et al., 2007; PERRY et al., 2007). Por outro lado, esta variação fenotípica tem sido associada à susceptibilidade a doenças devido ao fato das CNVs desempenharem papel funcional, seja em alterar a dosagem do gene, o nivel de expressão, ou mesmo por interferir na transcrição gênica (PTACEK et al., 2008; STRANGER et al., 2007; WILLCOCKS; SMITH; CLATWORTHY, 2009; WU et al., 2008). Os efeitos genômicos dessas variantes dependem da quantidade de cópias que são encontradas e da sua posição relativa nos genes ou nos elementos reguladores (WAIN; TOBIN, 2011). Por conseguinte, a variação quantitativa na dosagem gênica pode antecipar a sua contribuição para a variabilidade do risco na etiologia das doenças complexas entre os indivíduos (LAU; YIN; MOK, 2006) (VRIJENHOEK et al., 2008; YU et al., 2011).

Nos últimos anos, várias CNVs presentes no genoma humano tem sido associadas com doenças genéticas complexas, incluindo câncer (DISKIN et al., 2009; JACOB, K. et al., 2009), diabetes (GRAYSON et al., 2010), obesidade (BOCHUKOVA et al., 2010; WALTERS et al., 2010), infecção por HIV (GONZALEZ et al., 2005), doenças neurodegenerativas, como o autismo (SEBAT, 2007)e esquizofrenia (IKEDA et al., 2010) e doenças autoimunes, tais como glomerulonefrite (AITMAN et al., 2006), psoariase (HOLLOX et al., 2007) e lúpus eritematoso sistêmico (YANG, Y. et al., 2007). 


\section{LÚPUS ERITEMATOSO SISTÊMICO}

\section{O LÚPUS}

O Lúpus é uma doença genética complexa, caracterizada por uma resposta autoimune dirigida à antígenos nucleares e pela deposição de complexos imunes em diferentes tecidos (PTACEK et al., 2008). Isto resulta em uma inflamação local ou sistêmica, que muitas vezes evolui para disfunção ou mesmo para a falência dos órgãos (LAU et al., 2006).

O fenótipo da doença é extremamente heterogêneo, mesmo entre indivíduos aparentados. Existem evidências que demonstram o envolvimento tanto de fatores genéticos quanto ambientais, embora a etiologia da doença e os mecanismos de patogênese não tenham sido completamente elucidados (SANCHEZ et al., 2011; SARZI-PUTTINI et al., 2005).

O lúpus que apresenta quatro tipos principais: Lúpus Eritematoso Neonatal (LEN), Lúpus Induzido por Drogas (LID), Lúpus Eritematoso Discoide (LED) e o Lúpus Eritematoso Sistêmico (LES) (MAIDHOF; HILAS, 2012). O último é a forma mais comum e, portanto, o enfoque do trabalho. O LES diferencia-se de outras formas pelos seus efeitos multissistêmicos. É uma das doenças autoimunes mais heterogêneas. Há produção de uma variedade de autoanticorpos e a evolução da doença provoca manifestações clínicas polimórficas, com períodos de exacerbações e remissões (PONS-ESTEL et al., 2010).

\section{ETIOLOGIA}

O sistema imune representa a principal barreira do hospedeiro contra as infecções, e tem a capacidade distinguir o próprio do não próprio de modo a tolerar os autoantígenos e responder a antígenos estranhos (LETTRE; RIOUX, 2008). A tolerância é um estado imunológico de não responsividade ao próprio. Uma falha nos mecanismos normais de autotolerância resulta em reações contra as células e tecidos saudáveis do próprio organismo, que são 
chamadas de autoimunidade. Tais falhas podem ser causadas por defeitos no mecanismo de deleção clonal ou na regulação de linfócitos Th1 e Th2, perda da anergia da célula $T$, ativação policlonal de linfócitos, reação cruzada entre antígenos próprios e microbianos, entre outros (GUERRA; VYSE; GRAHAM, 2012).

A resposta imune hiperativa contra os antígenos autólogos gera inflamação e danos teciduais e tem potencial para conduzir a um amplo espectro de doenças autoimunes (GLEICHER; BARAD, 2007).

Acredita-se que fatores genéticos e ambientais são como gatilhos para a progressão de autoimunidade inofensiva para uma doença autoimune. Adicionalmente, o sexo parece ser um determinante importante visto que 75$80 \%$ dos pacientes que sofrem de doenças autoimunes são mulheres (AMUR; PAREKH; MUMMANENI, 2012).

O envolvimento multissistêmico é comumente observado em doenças autoimunes e os danos ao órgão-alvo principal geralmente conduz à apresentação clínica e caracteriza a doença (SATO, E.I., 2001). Devido aos estímulos para a resposta imune anormal serem dificeis ou impossíveis de eliminar e ao sistema imune possuir mecanismos de amplificação da resposta, uma vez que a resposta imune patológica comece, é difícil controlá-la ou terminá-la. Por tais razões, as doenças autoimunes tendem a ser crônicas e muitas vezes debilitantes (ABBAS; LICHTMAN; PILLAI, 2010).

As doenças autoimunes podem ser originadas por linfócitos T autorreativos, como no caso da diabetes tipo I e esclerose múltipla, ou por anticorpos. Estes, podem atuar contra células fixas e antígenos teciduais, como na anemia hemolítica e pênfigo vulgar, ou serem mediados por complexos imunes no caso do LES, e atingir, portanto mais tipos celulares, como antígenos nucleares e DNA (ABBAS et al., 2010).

Nesse contexto, a principal característica do LES é a formação de autoanticorpos que em combinação com antígenos, formam complexos imunes, levando, em última instância, à inflamação e ao dano tecidual (GUERRA et al., 2012). 
O envolvimento imunológico no LES centra-se na perda da autotolerância. Em pacientes com LES o processo de fagocitose é comprometido, o que leva à remoção inadequada de células apoptóticas e de complexos imunes (DORNER; GIESECKE; LIPSKY, 2010).

Entretanto, o mecanismo etiológico do LES não está suficientemente esclarecido, pois além dos fatores imunológicos envolvidos, os fatores genéticos, hormonais e ambientais também desempenham papel importante no desenvolvimento da doença (YANG, M. L. et al., 2012).

Estudos sobre a potencial ligação entre a genética e LES têm mostrado uma predisposição dentro de famílias. Parentes em primeiro grau de pacientes com LES são significativamente mais susceptíveis a doença em comparação com o restante da população (MAIDHOF; HILAS, 2012). Adicionalmente, foram descobertas de variantes genéticas ligadas à expressão do LES. Em geral, a combinação destas variantes conduz às manifestações clínicas do LES (HARLEY et al., 2009).

O efeito dos hormônios na taxa de ocorrência e na severidade do LES também tem sido relevante. O mecanismo pelo qual os hormônios afetam a prevalência de LES em mulheres permanece desconhecido. Uma hipótese centra-se no papel da progesterona, testosterona, dehidroepiandrosterona (DHEA), prolactina e dos estrogênios na resposta do sistema imune (SARZIPUTTINI et al., 2005).

Influências ambientais são claras, pois há exacerbação de alguns sintomas após exposição ao sol, infecção viral ou bacteriana e mudanças na atividade da doença após administração ou uso de algumas substâncias (MAIDHOF; HILAS, 2012). A luz ultravioleta estimula queratinócitos, o que leva à ativação de células B e produção de anticorpos, que pode induzir a atividade final das células $\mathrm{T}$, resultando na produção de autoanticorpos adicionais (CASCIOLAROSEN; ANHALT; ROSEN, 1994; LEHMANN et al., 1990). O hábito de fumar, algumas drogas (procainamida, hidralazina, minociclina, betabloqueadores, agentes anti-TNF), e até mesmo certos cosméticos são possiveis fatores que influenciam o desenvolvimento de lúpus (SATO, EMILIA INOUE et al., 2008). 


\section{PATOFISIOLOGIA}

O LES é uma doença crônica que afeta vários órgãos por desencadear a formação de autoanticorpos e deposição complexos imunes em diferentes tecidos (GUERRA et al., 2012).

Acredita-se que o LES é desenvolvido quando linfócitos T autorreativos reconhecem antígenos próprios via complexo principal de histocompatibilidade (MHC) de uma célula apresentadora de antígeno (APC), levando à liberação de citocinas, inflamação e ativação de células $B$ (RAVIRAJAN et al., 1998). As células B ativadas diferenciam-se em plasmócitos produtores de autoanticorpos, que causam danos teciduais em decorrência da sua formação e deposição na microvasculatura (DORNER et al., 2010; RAVIRAJAN et al., 1998)

Células B autorreativas produzem anticorpos contra antígenos expostos na superficie das células apoptóticas (BOUTS et al., 2012). Os autoantígenos que ativam as células $\mathrm{T}$ e células $\mathrm{B}$ em pacientes com LES podem ser atribuídos à eliminação inapropriada de células apoptóticas. Durante o processo de morte celular, fragmentos de material celular se formam na superficie da célula em apoptose, e apresentam-se na superficie celular. Consequentemente, esses resquícios celulares oferecem estímulo necessário para a ativação das células B autorreativas (MUNOZ et al., 2005).

Em resumo, a presença de células B autorreativas leva à produção de autoanticorpos, e em conjunto com a eliminação comprometida do material celular apoptótico, resulta na formação de complexos imunes. $\mathrm{Na}$ microvasculatura, estes complexos induzem reações autoimunes, causando a inflamação de inúmeros tecidos e consequentes danos associados ao LES (MAIDHOF; HILAS, 2012). 


\section{MANIFESTAÇÕES CLÍNICAS}

O LES é uma doença crônica que evolui apresentando períodos de atividade e remissão. Os pacientes apresentam grande variedade de manifestações clínicas devido ao comprometimento de múltiplos órgãos que ocorre de forma simultânea ou sequencial (LAU et al., 2006). Sinais e sintomas gerais incluem febre, fadiga, perda de peso, erupções cutâneas, artrite, nefrite, anemia e comprometimento do sistema nervoso central (Tabela 1) (SATO, EMILIA INOUE et al., 2008). Apesar de algumas manifestações clínicas serem comuns no LES, cada paciente apresenta um conjunto único de identificadores, devido à heterogeneidade da doença (PONS-ESTEL et al., 2010).

Tabela 1. Frequência das manifestações clínicas no Lúpus Eritematoso Sistêmico

\begin{tabular}{lcccc}
\hline \multicolumn{1}{c}{ Manifestações clínicas } & $\begin{array}{c}\text { Canadá } \\
n=750\end{array}$ & $\begin{array}{c}\text { Europa } \\
n=1000\end{array}$ & $\begin{array}{c}\text { EUA } \\
n=464\end{array}$ & $\begin{array}{c}\text { Brasil } \\
n=685\end{array}$ \\
\hline Artrite & 63 & 84 & 91 & 82 \\
Lesões cutâneas & 78 & - & 55 & 51 \\
Lesões mucosas & 52 & 24 & 19 & - \\
Pleuris & 30 & 36 & 31 & 24 \\
Comprometimento pulmonar & 14 & 7 & - & - \\
Pericardite & 23 & - & 12 & 15 \\
Fenômeno de Raynaud & 60 & 34 & 24 & 49 \\
Vasculite & 56 & - & - & 51 \\
Comprometimento renal & 74 & 39 & 28 & 52 \\
Azotemia & 5 & - & - & - \\
Comprometimento neurológico & 53 & 27 & 11 & 13 \\
Leucopenia/ Plaquetopenia & - & - & - & $30 / 13$ \\
Linfadenomegalia & 32 & 12 & 10 & 19 \\
\hline$n$ corresponde ao número de indivíduos que entraram na estimativa & Adaptado de Sato et al., 2008.
\end{tabular}




\section{CRITÉRIOS DE DIAGNÓSTICO}

O diagnóstico de LES é baseado em sinais e sintomas observados nos pacientes e em testes laboratoriais. Na prática, são utilizados os critérios de classificação propostos pelo American College of Rheumatology (ACR) em 1982 (TAN et al., 1982), e revisados em 1997 (HOCHBERG, M.C., 1997). A presença de quatro das onze manifestações clínico-laboratoriais é obrigatória para definir o diagnóstico da doença (Tabela 2) (BORBA et al., 2008). Os testes laboratoriais incluem a titulação de anticorpos antinucleares (ANAs) e dos autoanticorpos Anti-dsDNA e anti-Smith (Sm) (MAIDHOF; HILAS, 2012).

Tabela 2. Critérios do American College of Rheumatology para o diagnóstico de LES.

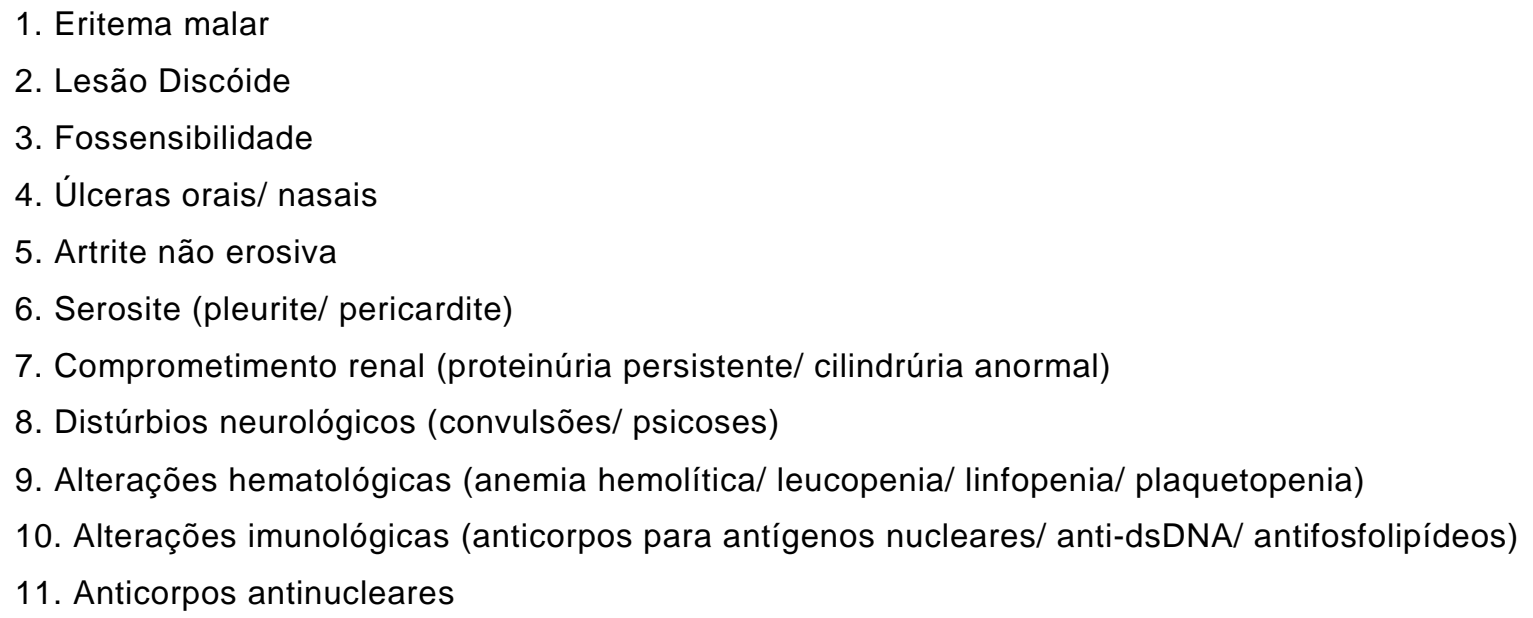

Adaptado de Borba et al., 2007.

\section{EPIDEMIOLOGIA}

A incidência de LES varia entre sexo, idade e ancestralidade. A prevalência na população geral é de aproximadamente 20 a 150 casos a cada 100.000 pessoas (MAIDHOF; HILAS, 2012).

O LES é mais comum em mulheres, principalmente em idade fértil. As estimativas apontam que LES acomete dez mulheres para cada homem afetado (SATO, EMILIA INOUE et al., 2008). Este aumento da incidência pode ser atribuído ao hormônio estrogênio. Estudos têm demonstrado que 
mulheres que tiveram menarca precoce, que usaram contraceptivos orais ou terapias hormonais apresentam um risco aumentado (COSTENBADER et al., 2007).

O risco em homens é semelhante ao de mulheres na pré-puberdade ou na pós-menopausa. A sindrome de Klinefelter, em que os homens possuem um cromossomo X extra, está ligada a uma incidência mais elevada de LES, fornecendo subsidios para a associação entre LES e a patogênese hormonal (SCOFIELD et al., 2008).

O LES tem distribuição global. Todavia, determinados grupos étnicos são mais susceptiveis a desenvolver esta condição. Em geral, as evidências sugerem que o LES é mais comum em afro-americanos, hispânicos, afrocaribenhos, índios nativos norte-americanos, orientais, incluindo indianos e chineses, do que em populações caucasianas (CLEMENS; SIITERI; STITES, 1979; COFFMAN; LEBMAN; ROTHMAN, 1993; HOCHBERG, M. C., 1987).

Além disso, a apresentação e o curso do LES são altamente variáveis entre os indivíduos de ancestralidade diferentes. Acredita-se que a doença seja mais grave entre os afro-americanos e orientais do que em caucasianos (LAU et al., 2006).

\section{BASE GENÉTICA DO LÚPUS ERITEMATOSO SISTÊMICO}

Evidências demonstram o envolvimento de fatores genéticos, embora a etiologia e os mecanismos da patogênese do LES não tenham sido completamente elucidados (AHMAD; BRUCE, 2001; SANCHEZ et al., 2011; SARZI-PUTTINI et al., 2005). Relatos que confirmam a relação do risco elevado de irmãos desenvolverem LES (ARDOIN; PISETSKY, 2008; MUSONE et al., 2008), a alta herdabilidade (>66\%) e as maiores taxas de concordância entre gêmeos monozigóticos (20-40\%) do que entre gêmeos dizigóticos e outros irmãos completos (2-5\%), sugerem que o LES possui uma base genética complexa (ALARCON-SEGOVIA et al., 2005) 
Nas década de 1990 e 2000, os genes de risco de LES foram investigados por meio de estudos de ligação que levaram à identificação do FCGR2A, FCGR3A e PDCD1 como candidatos (EDBERG et al., 2002; MOSER et al., 1998; PROKUNINA et al., 2002). No entanto, esses estudos limitaram-se à capacidade de identificar alelos causais e tinham baixo poder para mapear as variantes com pequeno efeito fenotípico, o que impediu o mapeamento completo do genoma (HARLEY et al., 2009).

Nos últimos anos, o aumento do conhecimento da estrutura do genoma humano e desenvolvimento tecnológico resultaram na disponibilidade de conjuntos de marcadores de alta densidade (MCCARTHY et al., 2008). Dessa forma, tornou-se possivel desenvolver estudos de associação genômica em larga escala (GWAS), com capacidade para rastrear milhares de SNPS em todo o genoma, sem conhecimento prévio de genes ou de regiões candidatas (CERVINO; TSINOREMAS; HOFFMAN, 2007). Atualmente, com o progresso realizado pela utilização dos recursos de alta densidade de genotipagem, existem mais de 30 loci identificados que mostram a associação robusta com LES (GUERRA et al., 2012; HARLEY et al., 2009) (Figura 2).

Adicionalmente, avaliou-se a contribuição dos loci previamente identificados para a heterogeneidade clínica no lúpus. Foram encontradas associações significativas entre as manifestações clinicas do LES e cinco loci. A doença renal foi correlacionada significativamente com o alelo de risco no gene ITGAM e em TNFSF. Outros achados significativos incluem a associação entre alelos de risco em FCGR2A e rash malar, gene ITGAM e erupção cutânea discóide, STAT4 e proteção contra úlceras orais e IL21 e alterações hematológicas (SANCHEZ et al., 2011). Os resultados sugerem que o perfil genético pode ser uma ferramenta útil para predizer as manifestações clínicas da doença em pacientes com lúpus no futuro. 


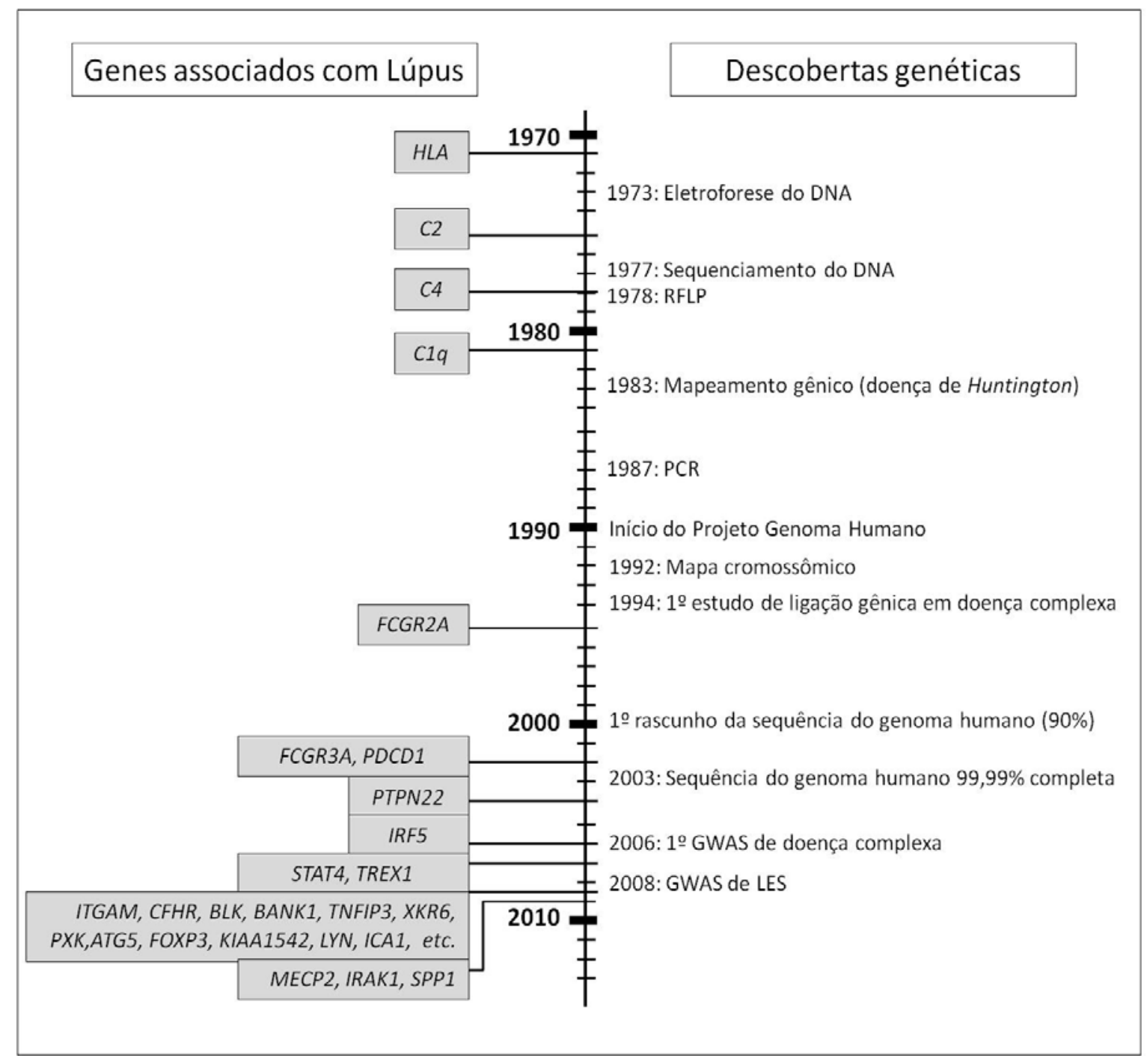

Figura 2. Paralelo entre as descobertas genéticas e a determinação de genes em associação com LES (Adaptado de KAISER; CRISWELL, 2010).

Há evidências crescentes de que outros tipos de variação genética, como as CNVs, são importantes para a complexidade da doença, algumas das quais só foram incluídas recentemente nos painéis de genotipagem por GWAS (GUERRA et al., 2012; HARLEY et al., 2009).

As pesquisas realizadas com CNVs e LES até o presente momento avaliaram variantes pontuais (MORRIS et al., 2010; PTACEK et al., 2008). Estudo independentes relataram, principalmente, CNVs nos genes FCGR3B (MCKINNEY et al., 2010), C4 (YANG, Y. et al., 2007) e nas interleucinas $I L$ $17 F$, IL-21 e IL-22 (YU et al., 2011). A redução no número de cópias de $F C G R 3 B$ e C4 é considerada fator de risco para desenvolvimento do LES (WU 
et al., 2008; Robinson, 2012 \#141), enquanto o aumento do número de cópias das interleucinas $I L-17 F$, IL-21 e $I L-22$ proporciona o mesmo efeito (YU et al., 2011). Entretanto, o perfil de CNVs em pacientes com LES permanece desconhecido, visto que a abordagem de triagem de CNVs em larga escala ainda não foi aplicada à doença.

Por conseguinte, cada associação recém-identificada apresenta novos desafios. Encontrar as variantes causais, entender como elas afetam a patofisiologia da doença e estabelecer sua contribuição para a susceptibilidade a LES permanece, em grande parte, inexplorada (SANCHEZ et al., 2011). 


\section{JUSTIFICATIVA}

Embora tenha ocorrido um progresso notável tanto em ensaios iniciais de GWAS como também em estudos de genes alvo do LES, ainda existem lacunas significativas na compreensão da base genética da doença.

A identificação recente de CNVs comuns no genoma humano como fonte de variação genética pode explicar, em parte, a susceptibilidade à autoimunidade (BRONSTAD, INGEBORG et al., 2011).

Os estudos atuais com CNVs e LES englobam a análise pontual das variantes (MORRIS et al., 2010; YU et al., 2011). Dessa forma, o delineamento do perfil da variação no número de cópias para LES torna-se necessário. Como não foi feita uma análise em larga escala sobre o padrão de CNVs e LES, pouco é relatado se serão encontradas CNVs comuns que se associam com LES, ou se indivíduos afetados possuirão CNVs mais raras, tal como observado na análise de CNVs em larga escala de doenças como a esclerose lateral aminotrófica (BLAUW et al., 2008) e esquizofrenia (VRIJENHOEK et al., 2008).

Com o intuito de compreender a relação entre as CNVs e o risco para desenvolver LES, nós propusemos um estudo que possibilitasse a varredura completa do genoma, por meio de ensaios de microarranjo, os quais apresentam alta capacidade de identificação das variantes.

Além da importância teórica, esta pesquisa torna-se pioneira na análise em larga escala das $C N V$ s em pacientes com LES. 


\section{HIPÓTESE}

A literatura sobre CNVs tem demonstrado a sua importância, sobretudo em condições patológicas. Baseando-se nos achados disponiveis até o momento, supomos que o perfil de CNVs identificadas nos pacientes portadores de LES será distinto daquele descrito para os indivíduos saudáveis. Dessa forma, por meio da avaliação da relevância funcional, serão descritas as regiões de $C N V s$ primordiais na relação com LES. Adicionalmente, como será aplicada uma tecnologia de alta resolução, serão eventualmente identificadas CNVs que ainda não foram descritas anteriormente. 


\section{OBJETIVOS}

\section{OBJETIVO GERAL}

O presente trabalho tem como objetivo geral promover análise em larga escala da distribuição de CNVs em amostra de pacientes portadores de LES.

\section{OBJETIVOS ESPECÍFICOS}

1. Detectar CNVs em pacientes com LES por meio da utilização da técnica de hibridação genômica em arrays $(a G H)$ com chips de DNA de alta densidade;

2. Delinear o perfil de CNVs encontrado no conjunto amostral e compará-1o com a literatura;

3. Determinar o padrão de recorrência de CNVs na amostra estudada e categorizá-las em regiões de CNVs (CNVRs);

4. Identificar possiveis novas $C N V s$ no conjunto amostral por meio da comparação das CNVs detectadas nos pacientes com LES com bancos de dados de variação estrutural do genoma. 


\section{MATERIAL E MÉTODOS}

\section{DESENHO EXPERIMENTAL}

A ideia inicial deste trabalho consistia em comparar frequências de marcadores genéticos moleculares em um grupo de pacientes portadores de LES com um grupo controle correspondente. Da consulta aos dados existentes, surgiram as $C N V s$ como marcadores possivelmente relacionados a LES e eventualmente também ligadas a distúrbios autoimunes.

A metodologia aqui empregada, de descrição relativamente recente, com a possibilidade de estudo, em um só chip de DNA, de 2,6 milhões de sondas dirigidas a este tipo de variação, bem como a de detectar 750 mil SNPs, demonstrou-se a mais indicada para atingir os objetivos propostos.

A novidade do tema e da técnica, que demandavam uma complexa implantação laboratorial, determinaram a readequação do tamanho amostral para 24 amostras de pacientes e sua comparação com dados da literatura sobre indivíduos normais. Nesse sentido, o perfil de CNVs em pacientes portadores de LES foi analisado por meio de ensaio de hibridação genômica em arrays $(a G H)$. A detecção de $C N V$ s foi realizada com a utilização da plataforma Affymetrix GeneChip System ${ }^{\circledR}$ Cytoscan $H D^{T M}$. A leitura dos chips foi feita pelo software Chromosome Analysis Suite (ChAS). O modelo de referência de microarrays que contem 380 amostras do projeto HapMap foi utilizado como base para comparação com as amostras de pacientes processadas. A determinação do padrão de CNVs para o grupo de pacientes incluiu identificar as CNVs comuns, raras e eventualmente novas. 


\section{COLABORADORES}

As amostras de pacientes portadores de LES foram gentilmente cedidas pelo Prof. Dr. Eduardo Antônio Donadi da Divisão de Clínica Médica da Faculdade de Medicina de Ribeirão Preto/USP.

A técnica de $a G H$ foi realizada no Laboratório de Genética Molecular do Departamento de Genética Médica, da Faculdade de Ciências Médicas/UNICAMP (Campinas, SP), sob a colaboração da Profa. Dra. Vera Lúcia Gil Lopes e da pós-doutoranda Profa. Dra. Milena Simioni.

As etapas finais da técnica de $a G H$ (lavagem, marcação e escaneamento dos chips) foram realizadas no Laboratório de Microarranjos do Laboratório Nacional de Biociências (LNBio) do Centro Nacional de Pesquisa em Energia e Materiais (CNPEM), em Campinas, SP.

\section{CASUÍSTICA}

Foram utilizadas 24 amostras de pacientes portadores de LES. Tais amostras foram anteriormente coletadas, mediante consentimento prévio, de pacientes não aparentados, atendidos e diagnosticados no ambulatório de Colagenoses da Clínica Médica da Faculdade de Medicina de Ribeirão Preto (HCFMRP, USP) para o projeto de pesquisa "Estudo da Neutropenia em Pacientes com Lúpus Eritematoso Sistêmico", sob responsabilidade do Prof. Dr. Eduardo Antônio Donadi e do pós-graduando João Alexandre Trés Pancoto. O DNA de tais amostras se encontrava extraído, uma vez que estas foram utilizadas em outros projetos já executados, todos previamente aprovados por Comissão de Ética (ver item Aspectos Éticos).

\section{Critérios de Seleção das amostras}

Os critérios de inclusão para a seleção das 24 amostras dos pacientes acometidos com LES foram os seguintes:

$1^{\circ}$ critério: Presença de nefrite lúpica;

$2^{\circ}$ critério: Lesões cutâneas; 
$3^{\circ}$ critério: Algum tipo de infecção;

$4^{\circ}$ critério: Manifestações neurológicas.

A amostra do projeto citado totaliza 185 individuos, dos quais foram selecionados seis homens e 18 mulheres. Todos os pacientes atenderam aos dois primeiros critérios de inclusão. O $3^{\circ}$ critério não foi atendido por apenas um dos pacientes dos pacientes do sexo masculino. $\mathrm{O} 4^{\circ}$ critério foi atendido por todas as mulheres e nenhum homem (Apêndice 1).

\section{ASPECTOS ÉTICOS}

As amostras provenientes de pacientes portadores de LES pertencem ao Banco de Amostras do Núcleo de Pesquisa em Imunogenética (BANPI) sob responsabilidade do Prof. Dr. Eduardo Antônio Donadi, aprovado pelo Comitê de Ética em Pesquisa do HCMRP-USP sob o processo n ${ }^{\circ} 7581 / 2007$.

O projeto para elaboração do presente trabalho: "CNVs em pacientes com Lúpus Eritematoso Sistêmico" foi aprovado pelo Comitê de Ética em Pesquisa do HCFMRP/USP, sob o processo n 72493/2012 (Apêndice 2).

\section{ANÁLISE LABORATORIAL}

\section{EXTRAÇÃO DO DNA GENÔMICO DAS AMOSTRAS DE PACIENTES}

Reagentes e soluções:

\section{Água ultrapura esterilizada}

EDTA 10\% pH 8,0: etilenediaminotetracetato dissódico $2 \mathrm{H}_{2} \mathrm{O}$.

Tampão para lise de eritrócitos (lise I): Tris/ $\mathrm{HCl} 0,01 \mathrm{M} \mathrm{pH} \mathrm{7,5;}$ Sacarose 0,32M; $\mathrm{MgCl} 2$ 5,0 mM; Triton X-100 1\%; $\mathrm{H}_{2} \mathrm{O}$ qsq para $1 \mathrm{~L}$.

Tampão para lise de leucócitos (lise II): $\mathrm{NaCl} 0,075 \mathrm{M}$; NaEDTA $0,024 \mathrm{M} ; 125 \mu \mathrm{L}$ de SDS $10 \% ; 1,1 \mathrm{~mL}$ de $\mathrm{NaClO}_{4} 5 \mathrm{M} ; \mathrm{H}_{2} \mathrm{O}$ qsq para $1 \mathrm{~L}$.

Cloreto de Sódio (NaCl): concentração 6M.

Isopropanol $100 \%$

Etanol 75\% 


\section{Procedimento:}

O DNA das amostras de sangue dos pacientes de LES foi extraído de acordo com o protocolo de salting-out detalhado a seguir (MILLER; DYKES; POLESKY, 1988).

Cerca de $10 \mathrm{~mL}$ de sangue foi coletado em tubo contendo EDTA como anticoagulante. $O$ sangue foi transferido para um tubo de $50 \mathrm{~mL}$ e adicionado $40 \mathrm{~mL}$ tampão de lise I gelado. Misturou-se delicadamente o conteúdo do tubo por inversão e centrifugaram-se os tubos por dez minutos a $3300 \mathrm{rpm}$ a $4^{\circ} \mathrm{C}$.

O sobrenadante (hemácias lisadas) foi descartado cuidadosamente e a extração prosseguiu com o pellet de células retido no fundo do tubo. O pellet de células foi ressuspenso em $4,5 \mathrm{~mL}$ de tampão de lise II. A mistura foi agitada em um Vortex por dez segundos a temperatura ambiente.

Adicionou-se $2 \mathrm{~mL}$ de $\mathrm{NaCI} 6 \mathrm{M}$ saturado por lisar as proteínas presentes. Agitou-se no Vortex por 15 segundos a temperatura ambiente.

Centrifugou-se o tubo por dez minutos a $3300 \mathrm{rpm}$. O sobrenadante foi transferido cuidadosamente para um tubo de $50 \mathrm{~mL}$. Adicionou-se $5 \mathrm{~mL}$ de isopropanol absoluto ao sobrenadante no tubo e homogeneizou-se gentilmente até que o DNA precipitasse.

O DNA foi retirado com auxílio de uma pipeta esterilizada e colocado em tubo de 1,5 mL (do tipo Eppendorf) contendo $1 \mathrm{~mL}$ de etanol $75 \%$ gelado. 0 tubo foi centrifugado por dez minutos a $4{ }^{\circ} \mathrm{C}$ e posteriormente o sobrenadante foi descartado. 0 tubo foi colocado em uma centrífuga a vácuo por dez minutos para que o restante do etanol fosse removido. O DNA no fundo do tubo foi dissolvido em $400 \mathrm{~mL}$ de água esterilizada e armazenado em refrigerador com temperatura aproximada de $-4^{\circ} \mathrm{C}$.

\section{AVALIAÇÃO DA INTEGRIDADE DO DNA}

Com o intuito de avaliar se o material genético apresentava-se íntegro, sem indícios de degradação do DNA, foi feita eletroforese em gel de agarose. Para verificar se a concentração e os graus de pureza do DNA seriam suficientes 
para conduzir os experimentos seguintes, o material foi quantificado em espectrofotômetro. O procedimento padrão para ambas as metodologias está descrito a seguir.

\section{ELETROFORESE EM GEL DE AGAROSE}

Reagentes e soluções:

\section{Agarose}

\section{Sybr Green}

Tampão TBE 1X (0,9M) pH 8,0: $1,08 \mathrm{~g}$ de Tris $(\mathrm{PM}=121,1) ; 0,53 \mathrm{~g}$ de ácido bórico; 4 mL de solução de EDTA; $\mathrm{H}_{2} \mathrm{O}$ qsp $1 \mathrm{~L}$.

\section{Tampão de amostra (Loading Buffer)}

\section{Procedimento:}

Inicialmente, $1 \mathrm{~g}$ de agarose foi misturada com $100 \mathrm{~mL}$ de Tampão TBE 1X, para a obtenção de um gel de agarose 1\%. A mistura foi levada ao forno micro-ondas até que ficasse homogênea. Adicionou-se $14 \mu \mathrm{L}$ de corante Sybr Green. O conteúdo foi derramado em uma cubeta com pentes posicionados para formarem os poços do gel e esperou-se a mistura solidificar. Logo, o suporte com o gel foi levado à cuba de eletroforese e tampão TBE $1 \mathrm{X}$ foi adicionado até cobrir a superficie do gel. Em seguida, $4 \mu \mathrm{L}$ da amostra de DNA foi homogeneizada com $4 \mu \mathrm{L}$ de tampão de corrida e aplicada nos poços do gel. A corrida eletroforética ocorreu com voltagem ajustada para $80 \mathrm{~V}$ por 30 minutos. O gel foi analisado sob radiação ultravioleta (UV), e registrado pela câmera acoplada ao visualizador.

\section{QUANTIFICAÇÃO E DILUIÇÃO DAS AMOSTRAS}

\section{$\underline{\text { Reagentes e soluções: }}$}

Affymetrix Inc., Santa Clara, CA, USA:

\section{Tampão TE Low EDTA}

\section{Procedimento:}

O DNA foi quantificado no espectrofotômetro de microplacas Epoch ${ }^{\mathrm{TM}}$ (BioTeK $\left.{ }^{\circledR}\right)$. O espectro de leitura de comprimentos de onda tem cobertura de 200 a 999 nm. A quantidade de $1 \mu \mathrm{L}$ de cada amostra é pipetada na microplaca e a Densidade Óptica (DO) é lida no espectrofotômetro. Os valores 
de concentração e pureza do DNA são gerados por meio da interface do software Gen5, acoplado ao Epoch ${ }^{\mathrm{TM}}$. Os padrões de pureza adequados devem possuir as razões de absorbância entre:

A260/A280: $1,7-2,0$

A260/A230: >1, 1

Em seguida, as amostras foram diluídas em tampão TE com EDTA, até a concentração de $50 \mathrm{ng} / \mu \mathrm{L}$. Para verificar a se a concentração atingiu o valor esperado, as amostras foram quantificadas novamente no espectrofotômetro.

\section{DETECÇÃO DE CNVs: HIBRIDAÇÃO GENÔMICA EM ARRAYS}

As $C N V$ s foram detectadas por meio da técnica de hibridação genômica em arrays $(a G H)$, utilizando a plataforma GeneChip System CytoScan $H D^{T M}$ (Affymetrix ${ }^{\circledR}$ ) e o kit de reagentes compativel, seguindo as recomendações do fabricante (código do produto: 901835). O chip CytoScan $H D^{T M}$ contém sondas de oligonucleotídeos com poder para detecção de alterações estruturais, com ampla cobertura do genoma, com capacidade para identificar aproximadamente 2,6 milhões de CNVs e 750 mil SNPs.

As 24 amostras foram processadas de acordo com o protocolo padrão do CytoScan HD (Affymetrix Inc., Santa Clara, CA, USA). O ensaio consistiu nas etapas descritas a seguir.

\section{DIGESTÃO DO DNA}

Reagentes e soluções:

Affymetrix Inc., Santa Clara, CA, USA:

\section{Água livre de nuclease}

Tampão TE Low EDTA

BSA 100X: concentração inicial $10 \mu \mathrm{g} / \mu \mathrm{L}$.

\section{Enzima NspI}

Tampão da NspI 10X: Tris- $\mathrm{HCl} 10 \mathrm{mM} ; \quad \mathrm{NaCl} \quad 50 \mathrm{mM} ; \quad \mathrm{MgCl}_{2}$ $10 \mathrm{mM}$; DTT $1 \mathrm{mM}$. 


\section{Procedimento:}

Inicialmente, $5 \mu \mathrm{L}$ do DNA a $50 \mathrm{ng} / \mu \mathrm{L}$ foram adicionados aos poços correspondentes de uma placa de 96 poços. Como controle positivo foi utilizado $5 \mu \mathrm{L}$ do DNA fornecido no kit e como controle negativo, $5 \mu \mathrm{L}$ de Tampão TE Low EDTA. Em seguida, a mistura da digestão foi preparada em um tubo de 1,5 mL contendo todos os reagentes: 11,55 $\mu \mathrm{L}$ de água livre de nuclease; 0,2 $\mu \mathrm{L}$ de BSA 100X; 2,0 $\mu \mathrm{L}$ de tampão da NspI 10X; 1,0 $\mu \mathrm{L}$ enzima $N s p I$ (quantidades para uma reação).

A mistura foi colocada no Vortex três vezes em alta velocidade, e distribuída igualmente em tubos conectados (strip). Com o auxílio de uma pipeta multicanal 14,75 $\mu \mathrm{L}$ foram adicionados aos poços de uma placa de 96 poços. A placa foi selada, colocada no Vortex uma vez em alta velocidade e centrifugada a $2000 \mathrm{rpm}$ durante um minuto. A este passo seguiu-se o programa do termociclador listado abaixo.

\section{Programa CytoScan Digest:}

$37^{\circ} \mathrm{C}$ por 2 horas;

$65^{\circ} \mathrm{C}$ por 20 minutos;

$4^{\circ} \mathrm{C}$ indefinidamente.

\section{LIGAÇÃO AOS ADAPTADORES}

Reagentes e soluções:

Affymetrix Inc., Santa Clara, CA, USA:

Adaptador, NspI: concentração $50 \mu \mathrm{M}$.

\section{Enzima T4 DNA Ligase}

Tampão da T4 DNA Ligase 10X: Tris- $\mathrm{HCl}(\mathrm{pH} 7.6) 660 \mathrm{mM} ; \mathrm{MgCl}_{2} 66$ $\mathrm{mM}$; DTT $100 \mathrm{mM}$; ATP $660 \mu \mathrm{M}$.

\section{Procedimento:}

Os fragmentos de DNA anteriormente digeridos pela enzima NspI apresentam, independente do tamanho, extremidades livres de $4 \mathrm{pb}$ de comprimento. Nesta etapa, adaptadores específicos são ligados a essas extremidades. Para que a reação ocorresse, a mistura da ligação foi preparada em um tubo de $1,5 \mathrm{~mL}$ contendo todos os reagentes: $0,75 \mu \mathrm{L}$ de 
adaptador NspI; 2,5 $\mu \mathrm{L}$ tampão da T4 DNA Ligase 10X; 2,0 $\mu \mathrm{L}$ enzima T4 DNA Ligase (quantidades para uma reação).

Em seguida, a mistura foi colocada no Vortex três vezes em alta velocidade, e distribuída igualmente em tubos conectados (strip). Com o auxílio de um pipeta multicanal $5,25 \mu \mathrm{L}$ foram adicionados aos poços de uma placa de 96 poços. A placa foi selada, colocada no Vortex uma vez em alta velocidade, e centrifugada a $2000 \mathrm{rpm}$ durante 1 minuto. A este passo seguiu-se o programa do termociclador listado abaixo.

\section{Programa CytoScan Ligate:}

$16^{\circ} \mathrm{C}$ por 3 horas;

$70^{\circ} \mathrm{C}$ por 20 minutos;

$4^{\circ} \mathrm{C}$ indefinidamente.

\section{AMPLIFICAÇÃO DOS FRAGMENTOS POR PCR}

Reagentes e soluções:

Affymetrix Inc., Santa Clara, CA, USA:
Água livre de nuclease
Reagente GC-Melt
dNTP: concentração 2,5 mM de cada ácido nucleico.
PCR Primer 002

Clontech Takara Bio, Moutain View, CA, USA:

Enzima Taq DNA Polimerase TITANIUMTM 50X: Glicerol 1\% $20 \mathrm{~mm}$; Tris-HCl (pH 8,0) 0,4 mM; KCl 2 mM; EDTA (pH 8,0) 2,0 $\mu \mathrm{M}$; Tween20: 0,005\%; Nonidet P-40: 0,005\%.

Tampão da Taq TITANIUMTM 10X: Tricina-KOH (pH 8,0) 40 mM; KCl 16 $\mathrm{mM} ; \mathrm{MgCl}_{2}$ 3,5 mM; BSA 3,75 $\mu \mathrm{g} / \mathrm{ml}$.

\section{Procedimento:}

Inicialmente, a placa contendo as amostras foi centrifugada a $2000 \mathrm{rpm}$ durante um minuto. As amostras foram diluídas em $75 \mu \mathrm{L}$ de água livre de nuclease. A placa foi devidamente selada e colocada no Vortex duas vezes e centrifugada novamente nas condições similares às citadas anteriormente. Quatro alíquotas de $10 \mu \mathrm{L}$ de cada amostra foram transferidas para outra placa de PCR. 
Em seguida, a mistura da ligação foi preparada em um tubo de $50 \mathrm{~mL}$ contendo todos os reagentes: $39,5 \mu \mathrm{L}$ de água livre de nuclease; 20,0 $\mu \mathrm{L}$ de reagente GC-Melt; 14,0 $\mu \mathrm{L}$ de dNTP; 4,5 $\mu \mathrm{L}$ de iniciador (PCR Primer 002); 10,0 $\mu \mathrm{L}$ tampão da Taq TITTANIUMTM 50X; 2,0 $\mu \mathrm{L}$ enzima Taq DNA Polimerase TITTANIUMTM (quantidades para uma reação).

A mistura foi colocada no Vortex três vezes em alta velocidade, e distribuída em um reservatório. Com o auxílio de um pipeta multicanal 90 $\mu \mathrm{L}$ foram adicionado aos poços das amostras. A placa foi selada, colocada no Vortex duas vezes em alta velocidade, e centrifugada a $2000 \mathrm{rpm}$ durante um minuto. A este passo seguiu-se o programa do termociclador listado abaixo. As condições da PCR foram otimizadas pelo fabricante para amplificar preferencialmente fragmentos entre 150 e $2000 \mathrm{pb}$.

\section{Programa CytoScan PCR:}

$94^{\circ} \mathrm{C}$ por 3 minutos;

$94^{\circ} \mathrm{C}$ por 30 segundos;

$60^{\circ} \mathrm{C}$ por 45 segundos;

$68^{\circ} \mathrm{C}$ por 15 segundos;

$68^{\circ} \mathrm{C}$ por 7 minutos;

$4^{\circ} \mathrm{C}$ indefinidamente.

\section{$1^{\circ}$ Ponto de Checagem}

Para checar se as etapas de digestão, ligação e amplificação do material ocorreram de forma correta, foi feita eletroforese em gel de agarose $2 \%$ do produto da PCR. Foi utilizado tampão de amostra (Lodding Dye) USB RapidRun $^{\mathrm{TM}} 5 X$ e marcador (ladder) USB 50-2000 pb. Como as condições da PCR foram otimizadas para amplificar fragmentos entre 150 e 2000 pb, o padrão de bandas visualizado no gel deveria corresponder a esse intervalo, como mostrado na Figura 3. 


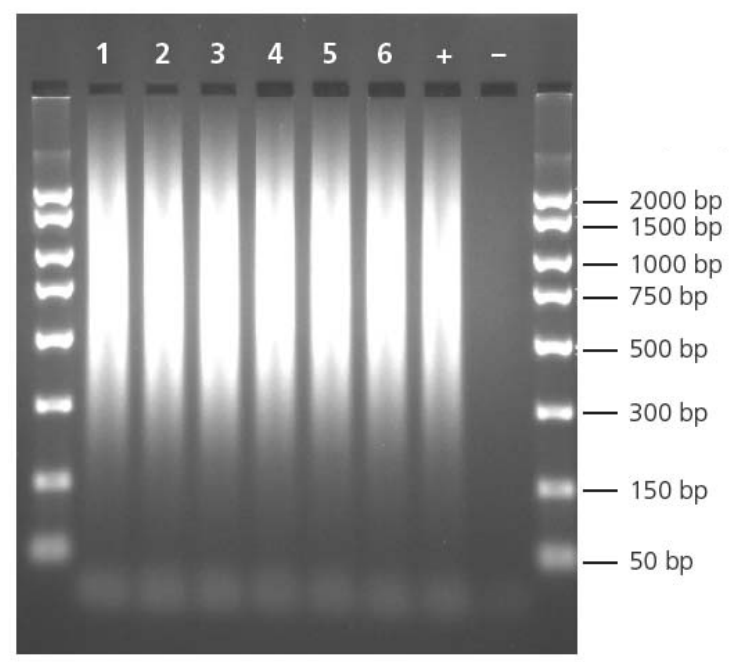

Figura 3. Padrão de bandas do gel de agarose $2 \%$ dos produtos amplificados da PCR. A maioria do material deve estar entre 150 e 2000 pb.

\section{PURIFICAÇÃO DOS PRODUTOS DA PCR}

Reagentes e soluções:

Affymetrix Inc., Santa Clara, CA, USA:

\section{Purification Beads}

Tampão de lavagem (Purification Wash Buffer)

Tampão de eluição (Elution Buffer)

\section{Procedimento:}

Os quatro produtos da PCR de cada amostra foram transferidos para tubos (tipo Eppendorf Safe-Lock) de 1,5 mL correspondentes. Foram adicionados $720 \mu \mathrm{L}$ do reagente Purification Beads em cada amostra. Cada tubo foi tampado, misturado por inversão e incubado a temperatura ambiente durante dez minutos.

Os tubos foram centrifugados a 16100 rcf durante três minutos e transferidos para um suporte magnético (MagnaRack ${ }^{\mathrm{TM}}$ Life Technologies). Deixando os tubos no suporte, o sobrenadante foi retirado e descartado, com auxílio de uma pipeta, sem que tocasse o precipitado.

Em seguida, 1,0 mL do tampão de lavagem foi adicionado a cada amostra. Os tubos foram tampados, e levados ao Vortex na velocidade máxima durante dois minutos. Centrifugou-se a 16100 rcf durante três minutos com 
as dobradiças dos tubos voltadas para fora na centrifuga. Os tubos foram levados de volta ao suporte magnético. Novamente o sobrenadante foi retirado e descartado, com auxílio de uma pipeta, sem que tocasse o precipitado. Centrifugou-se a 16100 rcf durante 30 segundos e quaisquer gotas do tampão de lavagem restantes foi removida do fundo do tubo com o auxílio de uma pipeta. Os tubos foram tirados do suporte magnético e deixados destampados durante dez minutos em temperatura ambiente, para assegurar que qualquer resíduo restante evaporasse.

Adicionou-se $52 \mu \mathrm{L}$ do tampão de eluição nas amostras. Os tubos foram tampados, colocados dentro de um adaptador de espuma e levados ao Vortex na velocidade máxima durante dez minutos para ressuspender o material aderido às Beads magnéticas. Centrifugou-se a 16100 rcf durante três minutos com as dobradiças dos tubos voltadas para fora na centrífuga. Os tubos foram colocados no suporte magnético por dez minutos, até que todas as Beads magnéticas aderissem a parede do tubo.

O volume de $47 \mu \mathrm{L}$ da amostra eluída foi transferido para o poço correspondente de uma placa de 96 poços. A placa foi devidamente selada, levada ao Vortex uma vez em alta velocidade, e centrifugada a $2000 \mathrm{rpm}$ durante um minuto.

\section{$\underline{2^{\circ} \text { Ponto de Checagem: }}$}

Para certificar que a purificação dos produtos da PCR garantiu condições ideais para o prosseguimento dos experimentos foi feita quantificação do DNA. $\mathrm{Na}$ avaliação das leituras de DO, os padrões atingidos devem ser:

Concentração: $\geq 2500 \mathrm{ng} / \mu \mathrm{L}$

Pureza: Razão A260/A280: 1,8 e 2,0

Medição A320: < 0,1 


\section{FRAGMENTAÇÃO}

Reagentes e soluções:

Affymetrix Inc., Santa Clara, CA, USA:

\section{Água livre de nuclease \\ Reagente de fragmentação \\ Tampão de fragmentação (Fragmentation Buffer)}

\section{Procedimento:}

Inicialmente, a placa contendo o produto purificado foi levada ao Vortex uma vez em alta velocidade e colocada sobre o bloco de refrigeração em gelo, onde permaneceu durante essa etapa.

Em seguida, a mistura da fragmentação foi preparada em um tubo de 1,5 $\mathrm{mL}$ contendo todos os reagentes: $122,4 \mu \mathrm{L}$ de água livre de nuclease; $7,2 \mu \mathrm{L}$ de reagente de fragmentação; $158,4 \mu \mathrm{L}$ de tampão de fragmentação (quantidades para oito reações).

A mistura foi colocado no Vortex três vezes em alta velocidade, e distribuído igualmente em tubos conectados (strip). Com o auxilio de um pipeta multicanal, adicionou-se $10,0 \mu \mathrm{L}$ aos poços de um placa de 96 poços. A placa foi selada, colocada no Vortex uma vez em alta velocidade e depois em uma centrífuga pré-refrigerada $\left(4^{\circ} \mathrm{C}\right)$ a $2000 \mathrm{rpm}$ durante um minuto. A este passo seguiu-se o programa do termociclador listado abaixo.

\section{Programa CytoScan Fragment:}

$37^{\circ} \mathrm{C}$ por 35 minutos;

$95^{\circ} \mathrm{C}$ por 15 minutos;

$4^{\circ} \mathrm{C}$ indefinidamente.

\section{$\underline{3^{\circ} \text { Ponto de Checagem }}$}

Para checar se a fragmentação ocorreu de forma esperada, foi feita eletroforese em gel de agarose 4\% do produto fragmentado. Foi utilizado tampão de amostra (Lodding Dye) USB RapidRun ${ }^{\mathrm{TM}} 5 X$ e marcador (ladder) TrackIt ${ }^{T M} 25 \mathrm{pb}$. O padrão de bandas visualizado no gel deveria corresponder 
ao intervalo de 25 a $125 \mathrm{pb}$ para confirmar que houve a fragmentação, como mostrado na Figura 4.

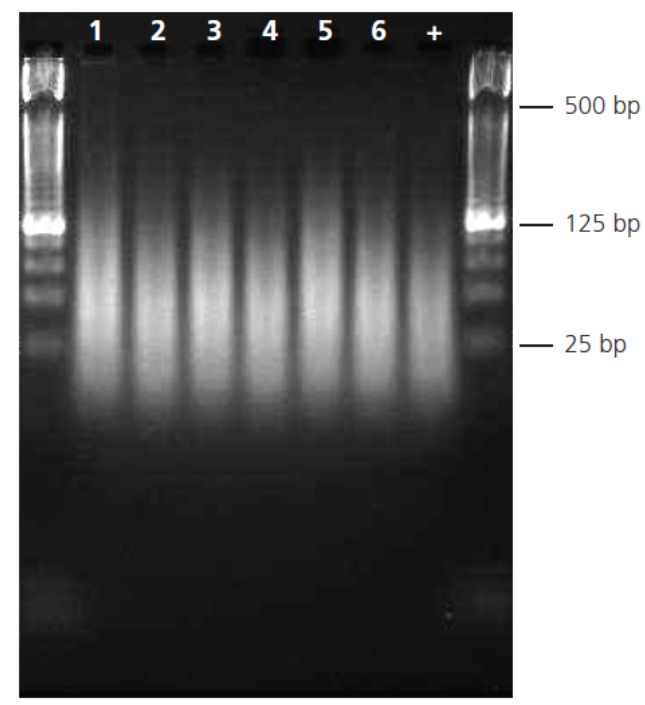

Figura 4. Padrão de bandas do gel de agarose $4 \%$ dos produtos fragmentados. A maioria do material deve estar entre 25 e 125 pb.

\section{PRÉ-MARCAÇÃO}

Reagentes e soluções:

Affymetrix Inc., Santa Clara, CA, USA:

Reagente de marcação do DNA: concentração 30 mM.

\section{Enzima TdT}

Tampão da TdT 5X: Ácido cacodílico (pH 6,8) 500mM; $\mathrm{CoCl}_{2} 5 \mathrm{mM}$; DTT $0,5 \mathrm{mM}$.

\section{Procedimento:}

A placa contendo o produto purificado foi levada ao Vortex uma vez em alta velocidade, e colocada sobre o bloco de refrigeração em gelo, onde permaneceu durante essa etapa.

Em seguida, a mistura da marcação foi preparada em um tubo de 1,5 mL contendo todos os reagentes: $2,0 \mu \mathrm{L}$ de reagente de marcação do DNA; 14,0 $\mu \mathrm{L}$ de tampão da $\operatorname{TdT} 5 \mathrm{X} ; 3,5 \mu \mathrm{L}$ de enzima $T d T$ (quantidades para uma reação). 
A mistura foi colocada no Vortex três vezes em alta velocidade, e distribuída igualmente em tubos conectados (strip). Com o auxílio de um pipeta multicanal $19,5 \mu \mathrm{L}$ foram adicionados aos poços de uma placa de 96 poços. A placa foi selada, colocada no Vortex uma vez em alta velocidade e depois em uma centifuga pré-refigerada $\left(4^{\circ} \mathrm{C}\right)$ a $2000 \mathrm{rpm}$ durante um minuto. A este passo seguiu-se o programa do termociclador listado abaixo.

\section{Programa CytoScan Label:}

$37^{\circ} \mathrm{C}$ por 4 horas;

$95^{\circ} \mathrm{C}$ por 15 minutos;

$4^{\circ} \mathrm{C}$ indefinidamente.

HIBRIDAÇÃO NOS CHIPS CYTOSCAN HD ${ }^{\mathrm{TM}}$

$\underline{\text { Reagentes e soluções: }}$

Affymetrix Inc., Santa Clara, CA, USA:

Reagente Oligo Control 0100

Tampão de hibridação 1 (Hyb Buffer Part 1)

Tampão de hibridação 2 (Hyb Buffer Part 2)

Tampão de hibridação 3 (Hyb Buffer Part 3)

Tampão de hibridação 4 (Hyb Buffer Part 4)

\section{Procedimento:}

Nesta fase, cada amostra foi hibridada em um chip CytoScan $H D^{T M}$ individual. Inicialmente, a mistura da hibridação foi preparada em um tubo de $15 \mathrm{~mL}$ contendo todos os reagentes: $165,0 \mu \mathrm{L}$ de tampão de hibridação 1 ; 15,0 $\mu \mathrm{L}$ tampão de hibridação $2 ; 7,0 \mu \mathrm{L}$ de tampão de hibridação 3; 1,0 $\mu \mathrm{L}$ de tampão de hibridação 4; 2,0 $\mu \mathrm{L}$ reagente Oligo Control 0100 (quantidades para uma reação).

A mistura foi colocada no Vortex três vezes em alta velocidade, e distribuído em um reservatório. Com o auxílio de um pipeta multicanal 190 $\mu \mathrm{L}$ foram adicionados aos poços das amostras. A placa foi selada, colocada no Vortex duas vezes em alta velocidade, e centrifugada a $2000 \mathrm{rpm}$ durante um minuto. A este passo seguiu-se o programa do termociclador listado abaixo. 


\section{Programa CytoScan Hyb:}

$95^{\circ} \mathrm{C}$ por 10 minutos;

$49^{\circ} \mathrm{C}$ indefinidamente.

Em seguida, deixando as amostras no termociclador, adicionou-se $200 \mu \mathrm{L}$ de amostra em cada chip individual. Antes dos chips serem vedados firmemente com adesivo, qualquer excesso de líquido em torno dos septos foi removido cuidadosamente. Imediatamente, os chips foram levados ao forno de hibridação (GeneChip ${ }^{\circledR}$ Hybridization Oven 640; Affymetrix Inc.), onde permaneceram por um período de 16 horas a $50^{\circ} \mathrm{C}$ e $60 \mathrm{rpm}$.

\section{LAVAGEM E MARCAÇÃO}

\section{Reagentes e soluções:}

Affymetrix Inc., Santa Clara, CA, USA:

Tampão de lavagem A (Wash Buffer A)

Tampão de lavagem $B$ (Wash Buffer B)

Tampão de coloração 1 (Stain Buffer 1)

Tampão de coloração 2 (Stain Buffer 2)

Tampão do array (Array Holding Buffer)

\section{Procedimento:}

Imediatamente após os chips serem retirados do forno de hibridação, o conteúdo no chip foi removido e substituído por $200 \mu \mathrm{L}$ de tampão do array (Array Holding Buffer). Em seguida, os chips foram inseridos na estação de lavagem (GeneChip ${ }^{\circledR}$ Fluidics Station 450; Affymetrix Inc.), quatro de cada vez. $\mathrm{Na}$ estação de lavagem foram executados dois passos: a remoção do excesso de marcador e coloração. Para tal, dois recipientes contendo os tampões de lavagem A e B foram posicionados na parte lateral do equipamento. Os tampões de coloração 1 e 2 e o tampão do array foram aliquotados em respectivos tubos do tipo Eppendorf de 1,5 mL. Cada conjunto de três tubos contendo os reagentes citados correspondeu a um chip e foi posicionado na parte frontal da estação. O programa para execução automática das etapas de lavagem e coloração dos chips CytoScan $H D^{T M}$ foi selecionado e teve duração de duas horas para cada conjunto de quatro chips. 


\section{ESCANEAMENTO}

Procedimento:

O equipamento GeneChip ${ }^{\circledR}$ Scanner $30007 G$ foi utilizado para gerar os resultados da varredura completa do genoma. São utilizados programas específicos para captação de imagem do GeneChip CytoScan HD Array analisado. A imagem dessa leitura pode ser observada com o programa de visualização GeneChip ${ }^{\circledR}$ Operating software (GCOS) (Affymetrix ${ }^{\circledR}$ ), no qual pode-se verificar o padrão das sondas controle do sistema, dispostas nas extremidades e no centro de cada chip, de forma a se comprovar que as condições de hibridação do microarranjo foram adequadas.

\section{ANÁLISE DOS DADOS}

\section{DETERMINAÇÃO DE CNVS PELO SOFTWARE ChAS}

O programa GCOS realiza a conversão da aglomeração das intensidades das sondas decorrentes do escaneamento dos chips em logaritmo. São gerados sete arquivos para cada amostra, dentre eles o arquivo com extensão .CEL, utilizado como input para a análise dos dados.

A determinação de CNVs a partir dos dados gerados por microarray é realizada pelo software Chromosome Analysis Suite v.1.2.2 (ChAS) (Affymetrix ${ }^{\circledR}$ ). O ChAS calcula a presença de CNVs baseado em dez etapas sucessivas. A estimativa do número de cópias neste programa é feita pelo cálculo do algoritmo Hidden Markov Model (HMM), enquanto que a determinação do sexo é feita pelo cálculo do algoritmo Y-Gender.

Os dados gerados na determinação de $C N V$ s pelo ChAS foram visualizados na forma de gráficos e tabelas. Nos gráficos, são observados log2 ratio, o weighted $\log 2$ ratio e o CNstate $(\mathrm{CN})$. O CN refere-se ao número de cópias de cada segmento genômico. A cópia diploide normal é representada pelo $\mathrm{CN}=2$, enquanto que $\mathrm{CN}<2(\mathrm{CN}=0$ ou $\mathrm{CN}=1)$ corresponde a deleção e $\mathrm{CN}>2(\mathrm{CN}=3$ ou $\mathrm{CN}=4$ ) corresponde a duplicação de segmentos genômicos. O programa gera, para cada indivíduo, uma tabela na forma de arquivo com extensão .txt, 
contendo informações relacionadas a cada CNV detectada, tais como: localização genômica exata (cromossomo, citobanda, posição inicial e final), o tamanho da $C N V$, os genes sobrepostos, total ou parcialmente, às CNVs e se estes estão presentes no OMIM ${ }^{\circledR}$ (Online Mendelian Inheritance in Man).

\section{MODELO DE REFERÊNCIA DE POPULAÇÕES DO PROJETO HAPMAP}

$\mathrm{O}$ arquivo modelo de referência do CytoScan HD ${ }^{\mathrm{TM}}$ (Affymetrix Inc., Santa Clara, CA, USA) incluiu os dados de CNV de 380 indivíduos controles executados como parte de um conjunto de nove operadores que processaram aproximadamente 48 amostras únicas em duas rodadas cada, com randomização dos amostras de DNA, reagentes e instrumentos utilizados.

A amostra de DNA consistiu em 284 amostras do projeto HapMap de três grupos étnicos distintos, contendo pelo menos uma réplica de cada uma das 270 amostras do HapMap (GIBBS et al., 2003): 90 africanos (Yoruba), 90 asiáticos e 90 caucasianos, derivadas de linhagens celulares pertencentes ao Instituto de Pesquisa Médica Coriell (Coriell Institute of Medical Research), e 96 amostras de DNA a partir de sangue de individuos saudáveis pertencentes a companhia BioServe Biotechnologies (BioServe, Beltsville, USA).

\section{PADRÕES DE QUALIDADE DOS EXPERIMENTOS}

Para avaliação da qualidade dos experimentos de $a G H$, três parâmetros recomendados pelo fabricante, que também fornece os valores de limiar, são estimados e indicam se os dados obtidos foram úteis para a análise do número de cópia $(\mathrm{CN})$.

\section{SNPQC}

SNPQC (Single Nucleotide Polymorphism Quality Control) é um parâmetro métrico que fornece informações sobre o nível global da qualidade dos dados a partir de uma perspectiva de SNPs. Esse indicador estima a distribuição dos alelos em homozigose (AA ou $\mathrm{BB}$ ) e em heterozigose (AB), calculando a distância entre eles. Quanto melhor a separação dessas distribuições, melhor 
é a capacidade de identificar o genótipo com base na sua posição no cluster. Microarrays com SNPQC $\geq 14$ são considerados de alta qualidade.

$\underline{M A P D}$

MAPD (Median Absolute Pairwise Difference) é a medida da variação de curto alcance do conjunto de sondas de microarray em todo o genoma. Esse parâmetro representa a mediana da distribuição das alterações no $\log 2$ ratio entre sondas adjacentes. Como o MAPD mede diferenças par a par entre sondas adjacentes os efeitos são medidos em curta distância no microarray. A variabilidade aumentada no $\log 2$ ratio diminui a qualidade da determinação do CN. Microarrays com MAPD $\leq 0,25$ são capazes de determinar o CN com clareza.

\section{WavinessSD}

WavinessSD (Waviness Standard Deviation) é a medida da variação de longo alcance do conjunto de sondas de microarray em todo o genoma. Esse parâmetro mede o desvio padrão do $\log 2$ ratio referente à extensão da faixa de variação em grandes segmentos. Microarrays com WavinessSD $\leq 0,12$ são considerados adequados.

\section{ANÁLISE PADRÃO}

$\mathrm{Na}$ detecção de CNVs pelo programa ChAS o número de marcadores necessários para definir as variantes foi limitado no mínimo de 25, no caso de deleção, e de 50, no caso de duplicação. Os limiares foram determinados de acordo com o que foi recomendado pela Affymetrix ${ }^{\circledR}$ como seguro na detecção de CNVs com pouco risco de resultados falso-positivos. A análise geral das CNVs seguiu tais limites especificados. Adicionalmente, as CNVs em que o programa utilizou os recursos smoothed/joined foram inspecionadas diretamente. Esses recursos podem ser definidos como:

\section{Smoothed}

Combina segmentos adjacentes que são ambos ganhos, mesmo que eles não tenham o mesmo $C N$ state. Por exemplo, o Smoothed combina um conjunto de segmentos adjacentes com $\mathrm{CN}=3$ com o de $\mathrm{CN}=4$, considera os 
dois como um só segmento e atribui o $C N$ state mais prevalente. O mesmo acontece para deleção $\mathrm{CN}=0$ e $\mathrm{CN}=1$. O Smoothed não combina os ganhos com perdas ou com segmentos normais.

\section{$\underline{\text { Joined }}$}

Combina segmentos de ganhos ou perdas se estes forem separados por intervalos pequenos dos segmentos com número de cópia normal $(\mathrm{CN}=2)$. Nesse recurso, se um segmento com $\mathrm{CN}=2$ com menos de 25 marcadores estiver entre dois segmentos adjacentes com o mesmo CN, os fragmentos com número de cópia normal serão removidos, e os segmentos adjacentes serão unidos.

Foi realizada uma análise visual cuidadosa das CNVs em que foram detectados segmentos com smoothed/joined com o intuito de filtrar as CNVs com risco de serem falso-positivas e eliminá-las das análises subsequentes.

\section{AVALIAÇÃO DAS CNVS DESCRITAS EM BANCOS DE DADOS}

Para considerar se determinada $C N V$ encontrada no conjunto amostral já havia sido descrita em bancos de dados de variantes estruturais, foi realizada uma busca pela região em que se encontrava a $C N V$ em sua exata localização genômica nas seguintes bases:

- Database

$(D G V$ http://projects.tcag.ca/variation): catálogo de CNVs encontradas em individuos saudáveis;

- UCSC Genome Bioinformatics (http://genome.ucsc.edu/) /Database of Chromosomal Imbalance and Phenotype in Humans using Ensembl Resources (DECIPHER, http: / /www.sanger. ac.uk/PostGenomics/DECIPHER/): catálogo de CNVs com potencial patogênico; 
- International Standards for Cytogenomic Arrays Consortium (ISCA, https://www.iscaconsortium.org/): catálogo de CNVs em regiões constitutivas do genoma.

Os casos em que não foram encontradas $C N V s$ no mesmo sentido na região descrita em dos nenhum bancos de dados citados foram enquadrados na categoria "CNVs não descritas em banco de dados".

\section{DETERMINAÇÃO DO PADRÃO DE RECORRÊNCIA DAS CNVS}

Com o intuito de determinar se as $C N V$ s foram de ocorrência única ou se estavam presentes em mais de um individuo analisado, considerou-se a localização genômica. As variantes agrupadas em "CNVs únicas" não apresentaram sobreposição com nenhuma outra CNVs identificada. Calculouse a sobreposição das demais $C N V s$, e as $C N V s$ compartilhadas, em parte ou absolutamente, foram agrupadas em regiões de CNVs (CNVRs). As CNVRs representam a região de $C N V s$ que se sobrepõe entre os indivíduos, ou seja, se duas ou mais CNVs tem a mesma localização genômica, a totalidade do segmento variável é agrupado em CNVR (Figura 5).

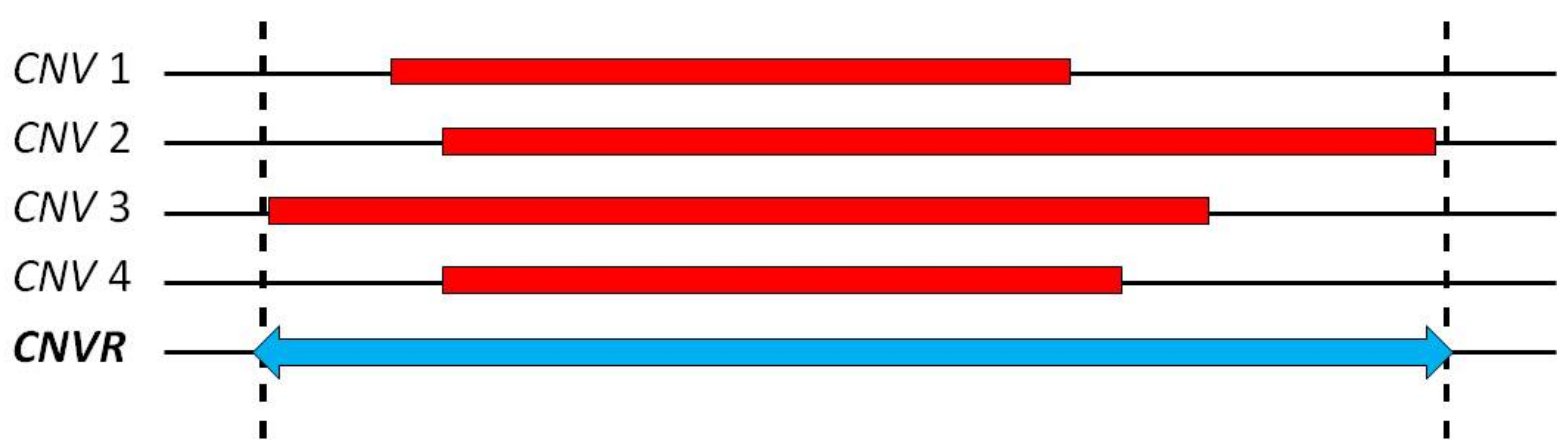

Figura 5. Representação de uma região de CNV. Quatro CNVs sobrepostas são consideradas uma CNVR.

\section{ANÁLISE DE REGIÕES ESPECÍFICAS: CYTOREGIONS}

$\mathrm{Na}$ análise padrão, o número mínimo de marcadores foi delimitado. Entretanto, para os genes candidatos de interesse realizou-se uma análise 
mais detalhada por meio da visualização de $C N V$ s sem número restrito de marcadores. Para proceder com a referida análise utilizou-se a ferramenta Cytoregions do programa ChAS que permite a busca de regiões ou genes de interesse devidamente selecionados para compor determinada Cytoregion. Os genes que compuseram as listas foram escolhidos com base na literatura. $\mathrm{O}$ critério utilizado para a seleção foi a presença dos genes em estudos de ligação em famílias e GWAS relacionados com autoimunidade, isto é, se determinado gene apresentou marcadores em que um dos alelos foi associado com autoimunidade; e genes com dosagem alterada encontrados em CNVs relacionadas com fenótipos autoimunes. Desse modo, foram criadas três Cytoregions. A primeira e a segunda possuíam, respectivamente, genes previamente relacionados com LES e genes envolvidos com doenças autoimunes, exceto com LES. A terceira era composta por uma lista de genes encontrados em CNVs relacionadas com autoimunidade (Apêndice 3). Após a busca dos genes por meio das Cytoregions no ChAS, os dados gerados foram exportados para planilha Microsoft Excel. 


\section{RESULTADOS}

\section{QUALIDADE DOS EXPERIMENTOS DE aGH}

Os 24 indivíduos portadores de LES foram analisados pela técnica de $a G H$. Após o processamento das amostras, verificou-se a qualidade dos experimentos.

Inicialmente, pelo programa GCOS (Affymetrix ${ }^{\circledR}$ ), a imagem de leitura do escaneamento dos chips foi visualmente inspecionada. Constatou-se problema de hibridação em um chip, mas os demais apresentaram padrão visual dentro do esperado e pode-se verificar os controles positivos do sistema de forma a se comprovar que as condições de hibridação do microarranjo foram adequadas.

Em seguida, os três parâmetros de qualidade: SNPQC, MAPD e WavineesSD (v. pag. 47-48, Material e Métodos), estimados pelo programa ChAS (Tabela 3) indicaram que o chip em que foi constatado problemas de hibridação apresentou valores insuficientes em dois parâmetros (SNPQC e $M A P D)$. Por tal razão, foi excluído das análises posteriores. Três outros chips, correspondentes aos pacientes 11, 17 e 18 mostraram valores (12, 13 e 13, respectivamente) pouco abaixo do limiar em relação ao $\operatorname{SNPQC}(\geq 14)$. Entretanto, esses não foram desconsiderados por se apresentarem dentro dos padrões para os outros parâmetros e valores de $\log 2$ Ratio adequados na apresentação gráfica pelo ChAS. Dessa forma, 23 chips foram processados na análise de $C N V s$. 
Tabela 3. Parâmetros de qualidade dos experimentos de aGH.

\begin{tabular}{|c|c|c|c|c|}
\hline Paciente & $\begin{array}{c}S N P Q C \\
\geq 14\end{array}$ & $\begin{array}{l}\text { MAPD } \\
\leq 0,25\end{array}$ & $\begin{array}{c}\text { WavinessSD } \\
\leq 0,12\end{array}$ & Situação \\
\hline 1 & 20 & 0,189 & 0,094 & Processado \\
\hline 2 & 15 & 0,180 & 0,078 & Processado \\
\hline 3 & 18 & 0,203 & 0,094 & Processado \\
\hline 4 & 16 & 0,191 & 0,078 & Processado \\
\hline 5 & 19 & 0,176 & 0,101 & Processado \\
\hline 6 & 20 & 0,192 & 0,086 & Processado \\
\hline 7 & 16 & 0,183 & 0,087 & Processado \\
\hline 8 & 14 & 0,190 & 0,086 & Processado \\
\hline 9 & 15 & 0,187 & 0,080 & Processado \\
\hline 10 & 16 & 0,179 & 0,076 & Processado \\
\hline 11 & $12^{*}$ & 0,206 & 0,082 & Processado \\
\hline 12 & 16 & 0,172 & 0,074 & Processado \\
\hline 13 & 21 & 0,185 & 0,092 & Processado \\
\hline 14 & 17 & 0,207 & 0,086 & Processado \\
\hline 15 & 20 & 0,188 & 0,090 & Processado \\
\hline 16 & 14 & 0,240 & 0,105 & Processado \\
\hline 17 & $13^{*}$ & 0,218 & 0,089 & Processado \\
\hline 18 & $13^{*}$ & 0,224 & 0,092 & Processado \\
\hline 19 & 20 & 0,190 & 0,090 & Processado \\
\hline 20 & 16 & 0,207 & 0,094 & Processado \\
\hline 21 & 19 & 0,203 & 0,090 & Processado \\
\hline 22 & 16 & 0,194 & 0,077 & Processado \\
\hline 23 & 20 & 0,217 & 0,100 & Processado \\
\hline 24 & $10^{*}$ & $0,259^{*}$ & 0,093 & Excluído \\
\hline
\end{tabular}

(*) Valores abaixo do limiar para o determinado parâmetro.

\section{ANÁLISE DAS CNVS}

\section{DISTRIBUIÇÃO DAS CNVS NA AMOSTRA DE PACIENTES COM LES}

A análise de CNVs pelo programa ChAS nos 23 pacientes com LES identificou um total de 406 CNVs (Tabela 4; Apêndice 4), 311 das quais foram do tipo deleção (18 com $\mathrm{CN}=0$ e 293 com $\mathrm{CN}=1$ ) e 95 duplicações $(82$ com $\mathrm{CN}=3$ e 13 com $\mathrm{CN}=4$ ). A média de $C N V$ s por pacientes correspondeu a 18. 
Tabela 4. Distribuição de CNVs nos pacientes com LES.

\begin{tabular}{|c|c|c|c|c|c|c|}
\hline \multirow{2}{*}{ Paciente } & \multirow{2}{*}{ Sexo } & \multirow{2}{*}{$\begin{array}{c}\text { Total de } \\
\text { CNVs }\end{array}$} & \multicolumn{2}{|c|}{ Deleções } & \multicolumn{2}{|c|}{ Duplicações } \\
\hline & & & $\mathrm{CN}=0$ & $\mathrm{CN}=1$ & $\mathrm{CN}=3$ & $\mathrm{CN}=4$ \\
\hline 1 & Masculino & 17 & 1 & 9 & 7 & 0 \\
\hline 2 & Masculino & 10 & 1 & 7 & 2 & 0 \\
\hline 3 & Masculino & 18 & 1 & 14 & 3 & 0 \\
\hline 4 & Masculino & 5 & 0 & 3 & 2 & 0 \\
\hline 5 & Masculino & 51 & 2 & 43 & 6 & 0 \\
\hline 6 & Feminino & 12 & 2 & 7 & 2 & 1 \\
\hline 7 & Feminino & 15 & 0 & 12 & 2 & 1 \\
\hline 8 & Feminino & 14 & 0 & 10 & 4 & 0 \\
\hline 9 & Feminino & 11 & 0 & 6 & 5 & 0 \\
\hline 10 & Feminino & 17 & 0 & 10 & 6 & 1 \\
\hline 11 & Feminino & 20 & 1 & 12 & 6 & 1 \\
\hline 12 & Feminino & 14 & 0 & 10 & 4 & 0 \\
\hline 13 & Feminino & 17 & 1 & 13 & 2 & 1 \\
\hline 14 & Feminino & 16 & 1 & 11 & 3 & 1 \\
\hline 15 & Feminino & 14 & 1 & 11 & 1 & 1 \\
\hline 16 & Feminino & 31 & 1 & 22 & 6 & 2 \\
\hline 17 & Feminino & 13 & 1 & 6 & 5 & 1 \\
\hline 18 & Feminino & 15 & 0 & 14 & 1 & 0 \\
\hline 19 & Feminino & 23 & 2 & 19 & 2 & 0 \\
\hline 20 & Feminino & 13 & 1 & 11 & 0 & 1 \\
\hline 21 & Feminino & 21 & 0 & 16 & 3 & 2 \\
\hline 22 & Feminino & 17 & 1 & 12 & 4 & 0 \\
\hline 23 & Feminino & 22 & 1 & 15 & 6 & 0 \\
\hline Total & & 406 & 18 & 293 & 82 & 13 \\
\hline
\end{tabular}

CN = Copy Number state; número de cópias do segmento genômico deletado ou duplicado.

\section{DISTRIBUIÇÃO DE TAMANHO DAS CNVS IDENTIFICADAS}

As CNVs identificadas na amostra apresentaram tamanhos variados. A maioria delas enquadrou-se na faixa de tamanho entre 10 a $100 \mathrm{~kb}$ (Figura 6). Todos os pacientes apresentaram $C N V s$ entre 10 a $450 \mathrm{~kb}$ (Tabela 5). Em 
relação às grandes CNVs (maiores do que $450 \mathrm{~kb}$ ), a maioria dos pacientes possui pelo menos uma $C N V$ dessa especificação (Tabela 6). Entretanto, CNVs menores do que $1 \mathrm{~kb}$ foram apresentadas por somente dois pacientes.

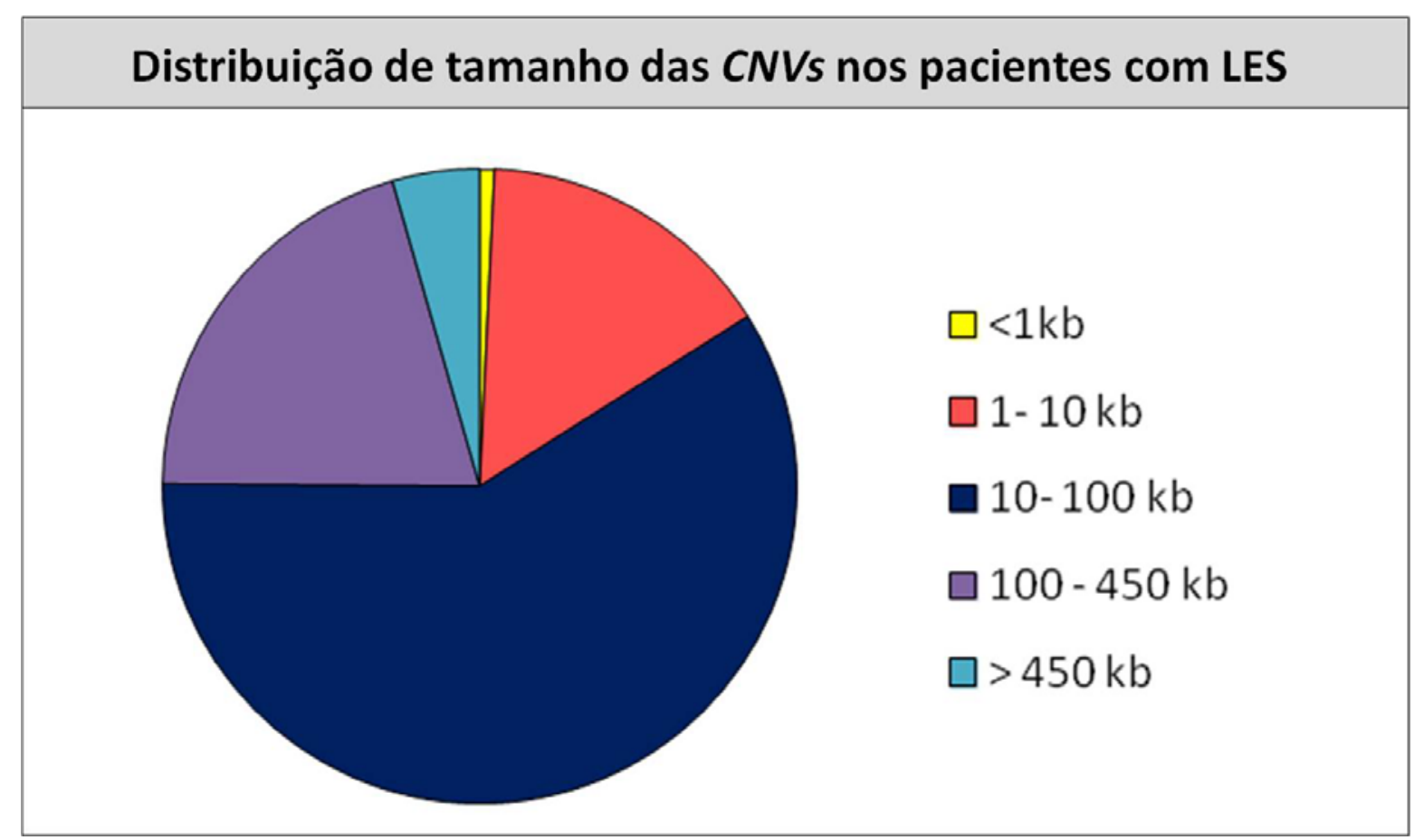

Figura 6. Gráfico mostrando a distribuição de tamanhos das CNVs nas amostras de LES.

Tabela 5. Distribuição das faixas de tamanho das CNVs encontradas nos pacientes.

\begin{tabular}{llll}
\hline Tamanho da CNV & \multicolumn{2}{l}{ Total de CNVs } & Total de pacientes \\
\hline$<1 \mathbf{k b}$ & 3 & $0,7 \%$ & 2 \\
$\mathbf{1}-\mathbf{1 0} \mathbf{~ k b}$ & 62 & $15,3 \%$ & 22 \\
$\mathbf{1 0}-\mathbf{1 0 0} \mathbf{~ k b}$ & 240 & $59,1 \%$ & Todos \\
$\mathbf{1 0 0}-\mathbf{4 5 0} \mathbf{~ k b}$ & 83 & $20,4 \%$ & Todos \\
$>\mathbf{4 5 0} \mathbf{~ k b}$ & 18 & $4,4 \%$ & 16 \\
\hline Total & $\mathbf{4 0 6}$ & $\mathbf{2 3}$ \\
\hline
\end{tabular}


Tabela 6. Grandes CNVs (>450 kb) identificadas na amostra de pacientes com LES.

\begin{tabular}{|c|c|c|c|c|c|c|c|}
\hline $\begin{array}{l}\text { Localização } \\
\text { Genômica }\end{array}$ & Início & Fim & $\begin{array}{l}\text { Tamanho } \\
\text { (kb) }\end{array}$ & Tipo & Genes & Pacientes & $\begin{array}{l}\mathrm{n}^{\circ} \mathrm{de} \\
\text { CNVs }\end{array}$ \\
\hline $1 q 21.1$ & 144086896 & 144567360 & 480 & Duplicação & $\begin{array}{l}\text { SRGAP2P2, LOC728855, LOC728875, PPIAL4B, } \\
\text { PPIAL4C, PPIAL4A }\end{array}$ & 23 & 1 \\
\hline 11p11.12 & 50480770 & 51228126 & 747 & Deleção & & 7 & 1 \\
\hline $11 \mathrm{p} 11.12$ & 50344786 & 51267021 & 922 & Deleção & LOC646813 & 5 & 1 \\
\hline $12 \mathrm{p} 12.1$ & 21796951 & 22445614 & 648 & Duplicação & LDHB, KCNJ8, ABCC9, CMAS, ST8SIA1 & 11 & 1 \\
\hline $14 q 32.33$ & 106274525 & 106728149 & 453 & Duplicação & KIAA0125, ADAM6 & 6 & 1 \\
\hline $14 q 32.33$ & 106246288 & 106761968 & 515 & Duplicação & KIAA0125, ADAM6, NCRNA00226 & 16 & 1 \\
\hline $14 q 32.33$ & 106329183 & 106849677 & 520 & Duplicação & KIAA0125, ADAM6, NCRNA00226 & 10 & 1 \\
\hline $14 q 32.33$ & 106329183 & 106876355 & 547 & Duplicação & KIAA0125, ADAM6, NCRNA00226 & 1 & 1 \\
\hline $14 q 32.33$ & 106329183 & 106896439 & 567 & Duplicação & KIAA0125, ADAM6, NCRNA00226 & 22 & 1 \\
\hline $14 q 32.33$ & 106207204 & 106931309 & 724 & Duplicação & KIAA0125, ADAM6, NCRNA00226 & 3 & 1 \\
\hline $14 q 32.33$ & 106329183 & 107179594 & 850 & Duplicação & KIAA0125, ADAM6, NCRNA00226, NCRNA00221 & 19 & 1 \\
\hline 16p11.2 & 32554241 & 33754119 & 1200 & Duplicação & TP53TG3B, TP53TG3, SLC6A10P, LOC390705 & 9 & 1 \\
\hline $17 q 21.31$ & 44212823 & 44784639 & 571 & Duplicação & $\begin{array}{l}\text { KIAA1267, LOC644246, LRRC37A, ARL17A, } \\
\text { ARL17B, NSFP1, LRRC37A2, NSF }\end{array}$ & 5,12 & 2 \\
\hline $17 q 21.31$ & 44190670 & 44784639 & 593 & Duplicação & $\begin{array}{l}\text { KIAA1267, LOC644246, LRRC37A, ARL17A, } \\
\text { ARL17B, NSFP1, LRRC37A2, NSF }\end{array}$ & 14 & 1 \\
\hline $17 q 21.31$ & 44188450 & 44784639 & 596 & Duplicação & $\begin{array}{l}\text { KIAA1267, LOC644246, LRRC37A, ARL17A, } \\
\text { ARL17B, NSFP1, LRRC37A2, NSF }\end{array}$ & 17 & 1 \\
\hline $17 q 21.31$ & 44187491 & 44784639 & 597 & Duplicação & $\begin{array}{l}\text { KIAA1267, LOC644246, LRRC37A, ARL17A, } \\
\text { ARL17B, NSFP1, LRRC37A2, NSF }\end{array}$ & 6,7 & 2 \\
\hline
\end{tabular}




\section{DISTRIBUIÇÃO DE CNVS NOS CROMOSSOMOS}

As 406 CNVs identificadas na análise geral distribuíram-se por todos os cromossomos, exceto no Y (Figura 7). Em contrapartida, o cromossomo X foi o que concentrou o maior número de CNVs, totalizando 87. Os cromossomos 18 e 21 apresentaram apenas $1 C N V$, ambas detectadas no paciente 22 .

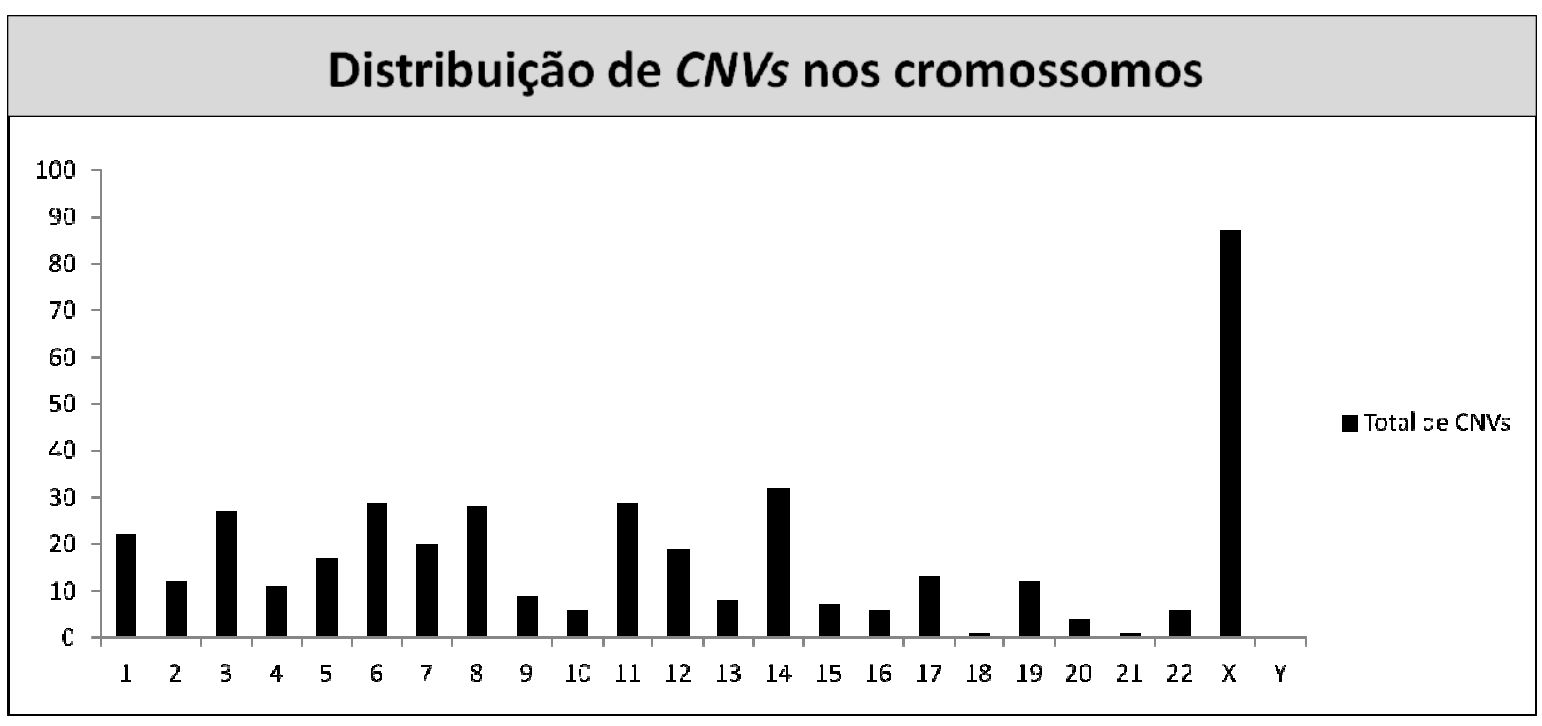

Figura 7. Distribuição das CNVs encontradas por cromossomo.

\section{PADRÃO DE RECORRÊNCIA DAS CNVS}

Considerando a amostra total, 152 CNVs foram detectadas em apenas um individuo. Essas CNVs de ocorrência única estão distribuídas por todos os cromossomos, exceto no Y (Tabela 7).

Por meio da análise de sobreposição das CNVs detectadas, foram encontradas 252 CNVs compartilhadas entre dois ou mais individuos. Tais CNVs foram distribuídas em 59 CNVRs (Tabela 8). 
Tabela 7. Recorrência das CNVs por cromossomo.

\begin{tabular}{|c|c|c|c|}
\hline Cromossomo & Total de CNVs & CNVs únicas & CNVRS \\
\hline 1 & 22 & 10 & 3 \\
\hline 2 & 12 & 6 & 2 \\
\hline 3 & 27 & 9 & 5 \\
\hline 4 & 11 & 5 & 2 \\
\hline 5 & 17 & 7 & 2 \\
\hline 6 & 29 & 11 & 3 \\
\hline 7 & 20 & 9 & 4 \\
\hline 8 & 28 & 9 & 1 \\
\hline 9 & 9 & 9 & 0 \\
\hline 10 & 6 & 2 & 1 \\
\hline 11 & 29 & 4 & 6 \\
\hline 12 & 19 & 4 & 4 \\
\hline 13 & 8 & 4 & 1 \\
\hline 14 & 32 & 5 & 2 \\
\hline 15 & 7 & 5 & 1 \\
\hline 16 & 6 & 3 & 1 \\
\hline 17 & 13 & 1 & 3 \\
\hline 18 & 1 & 1 & 0 \\
\hline 19 & 12 & 3 & 3 \\
\hline 20 & 4 & 2 & 1 \\
\hline 21 & 1 & 1 & 0 \\
\hline 22 & 6 & 6 & 0 \\
\hline$x$ & 87 & 36 & 14 \\
\hline$Y$ & 0 & 0 & 0 \\
\hline Total & 406 & 152 & 59 \\
\hline
\end{tabular}


Tabela 8. CNVRs encontradas nos pacientes com LES.

\begin{tabular}{|c|c|c|c|c|c|c|c|}
\hline $\begin{array}{l}\text { Localização } \\
\text { genômica }\end{array}$ & Início & Fim & $\begin{array}{l}\text { Tamanho } \\
(\mathrm{Kb})\end{array}$ & $\begin{array}{c}\text { CNVs } \\
\text { incluídas } \\
\text { nas CNVRs }\end{array}$ & Genes envolvidos & Pacientes & $\begin{array}{l}\text { Número de } \\
\text { pacientes }\end{array}$ \\
\hline $1 q 21.3$ & 152761910 & 152773905 & 12,0 & $2 \mathrm{del}$ & LCE1D & 3,21 & 2 \\
\hline 1q32.2 & 210604732 & 210612839 & 8,1 & 3 del & HHAT & 15,18 & 3 \\
\hline $1 q 44$ & 248688586 & 248795277 & 106,7 & 8 del & $\begin{array}{l}\text { OR2T29, OR2T34, } \\
\text { OR2T10, OR2T11 }\end{array}$ & $1,2,7,11,12,19,20,23$ & 8 \\
\hline $2 q 33.1$ & 203293011 & 203313469 & 20,5 & 2 del & BMPR2 & 10,19 & 2 \\
\hline $2 q 34$ & 213163737 & 213192832 & 29,1 & 4 del & ERBB4 & $5,8,16,21$ & 4 \\
\hline $3 p 21.31$ & 46780900 & 46872554 & 91,7 & $7 \mathrm{del}$ & PRSS45, PRSS42 & $3,5,6,8,11,18,22$ & 7 \\
\hline 3p21.1 & 53031722 & 53038931 & 7,2 & $2 \mathrm{del}$ & SFMBT1 & 1,23 & 2 \\
\hline $3 p 11.1$ & 89387087 & 89419367 & 32,3 & 3 del & EPHA3 & $9,17,20$ & 3 \\
\hline $3 q 21.2$ & 125708696 & 125721849 & 13,2 & 2 del & - & 22,23 & 2 \\
\hline $3 q 28$ & 189360266 & 189371964 & 11,7 & $4 \mathrm{del}$ & TP63 & $3,12,14,23$ & 4 \\
\hline $4 q 13.2$ & 69435888 & 69551731 & 115,8 & 4 del & UGT2B15 & $5,15,22,19$ & 4 \\
\hline $4 q 24$ & 104199891 & 104251349 & 51,5 & $2 \mathrm{del}$ & - & 18,22 & 2 \\
\hline $5 p 11-5 p 12$ & 45915731 & 46377314 & 461,6 & $2 \mathrm{del}$ & - & 5,13 & 2 \\
\hline $5 q 35.3$ & 180378753 & 180430789 & 52,0 & 8 del & BTNL3 & $2,9,13,14,15,21,22,23$ & 8 \\
\hline $6 p 25.3$ & 254253 & 381137 & 126,9 & $7 \mathrm{del} / 2 \mathrm{dup}$ & DUSP22 & $2,6,9,11,13,14,17,19,20$ & 9 \\
\hline $6 q 12$ & 67004972 & 67051189 & 46,2 & $4 \mathrm{del}$ & - & 6. $17,18,19$ & 4 \\
\hline $6 q 14.1$ & 78866468 & 79051614 & 185,1 & 4 del/1 dup & - & $3,4,5,10,11$ & 5 \\
\hline $7 p 22.3$ & 154720 & 158615 & 3,9 & 5 del & - & $6,10,12,15,22$ & 5 \\
\hline 7p14.1 & 38319295 & 38349129 & 29,8 & 2 del & - & 14,19 & 2 \\
\hline $7 q 22.1$ & 100968362 & 101141867 & 173,5 & 2 dup & EMID2 & 12,13 & 2 \\
\hline 7q34 & 142453878 & 142485841 & 32,0 & 2 del & PRSS1, TRY6, PRSS2 & 14,19 & 2 \\
\hline 8p11.22 & 39225874 & 39389003 & 163,1 & $19 \mathrm{del}$ & ADAM5P, ADAM3A & $\begin{array}{l}1,2,4,5,6,7,9,10,11,12,13,14 \\
15,16,17,18,20,21,22\end{array}$ & 19 \\
\hline
\end{tabular}




\begin{tabular}{|c|c|c|c|c|c|c|c|}
\hline $10 q 26.3$ & 135228992 & 135427143 & 198,2 & 4 dup & $\begin{array}{l}\text { MTG1, SPRN, } \\
\text { LOC619207, CYP2E1, } \\
\text { SYCE1, SPRNP1 }\end{array}$ & $1,10,11,22$ & 4 \\
\hline 11p15.4 & 5783909 & 5812365 & 28,5 & $8 \mathrm{del}$ & OR52N5, OR52N1 & $1,5,6,10,11,14,16,20$ & 8 \\
\hline 11p15.1 & 18941196 & 18971367 & 30,2 & $1 \mathrm{del} / 2 \mathrm{dup}$ & MRGPRX1 & $1,9,17$ & 5 \\
\hline 11p11.2 & 48658169 & 48892181 & 234,0 & $2 \mathrm{del}$ & - & 5,13 & 2 \\
\hline $11 p 11.12$ & 50344786 & 51267021 & 922,2 & $2 \mathrm{del}$ & LOC646813 & 5,7 & 2 \\
\hline $11 q 11$ & 54701631 & 55039246 & 337,6 & $2 \mathrm{del}$ & TRIM48 & 13,23 & 2 \\
\hline $11 q 11$ & 55374018 & 55452996 & 79,0 & $8 \mathrm{del}$ & OR4P4, OR4S2, OR4C6 & $3,5,6,11,12,15,19,22$ & 8 \\
\hline $12 \mathrm{p} 13.2$ & 11216816 & 11256728 & 39,9 & $4 \mathrm{del}$ & PRR4, PRH1, TAS2R43 & $8,18,20,23$ & 4 \\
\hline $12 \mathrm{p} 11.23$ & 27646150 & 27659531 & 13,4 & $3 \mathrm{del}$ & C12orf70 & $1,2,15$ & 3 \\
\hline 12p11.21 & 31265043 & 31407111 & 142,1 & 2 dup & - & 10,12 & 2 \\
\hline $12 q 23.1$ & 99791638 & 99798721 & 7,1 & $6 \mathrm{del}$ & ANKS1B & $4,5,13,19,20,23$ & 6 \\
\hline $13 q 21.1$ & 57750940 & 57778367 & 27,4 & $4 \mathrm{del}$ & - & $3,8,16,19$ & 4 \\
\hline $14 q 11.2$ & 22578241 & 22944507 & 366,3 & $4 \mathrm{del}$ & - & $3,14,19$ & 3 \\
\hline $14 q 32.33$ & 106207204 & 107184184 & 977,0 & 23 dup & $\begin{array}{l}\text { KIAA0125, ADAM6, } \\
\text { NCRNA00226, } \\
\text { NCRNA00221 }\end{array}$ & $\begin{array}{l}1,2,3,4,5,6,7,8,9,10,11,13,14 \\
16,17,18,19,21,22,23\end{array}$ & 20 \\
\hline $15 q 11.2$ & 24363482 & 24485873 & 122,4 & $2 \mathrm{del}$ & PWRN2 & 6,20 & 2 \\
\hline $16 q 12.2$ & 55796375 & 55821956 & 25,6 & $3 \mathrm{del}$ & CES1P1 & $7,14,21$ & 3 \\
\hline $17 q 12$ & 36283806 & 36410559 & 126,8 & $4 \mathrm{del}$ & TBC1D3F, TBC1D3 & 3,5 & 4 \\
\hline $17 q 21.2$ & 39511103 & 39526296 & 15,2 & $2 \mathrm{del}$ & KRT33B & 7,18 & 2 \\
\hline $17 q 21.31$ & 44187491 & 44784639 & 597,1 & 8 dup & $\begin{array}{l}\text { KIAA1267, LOC644246, } \\
\text { LRRC37A, ARL17A, } \\
\text { ARL17B, NSFP1, } \\
\text { LRRC37A2, NSF }\end{array}$ & $1,5,6,7,8,12,14,17$ & 8 \\
\hline $19 p 13.12$ & 15777995 & 15833442 & 55,4 & 2 dup & CYP4F12 & 2,10 & 2 \\
\hline $19 p 12$ & 20588836 & 20830021 & 241,2 & 2 del & $\begin{array}{l}\text { ZNF826P, ZNF737, } \\
\text { ZNF626 }\end{array}$ & 11,13 & 2 \\
\hline $19 q 13.2$ & 41352625 & 41392187 & 39,6 & $5 \mathrm{del}$ & CYP2A6, CYP2A7 & $1,7,12,19,23$ & 5 \\
\hline $20 q 13.2$ & 52652344 & 52658506 & 6,2 & $2 \mathrm{del}$ & BCAS1 & 7,21 & 2 \\
\hline Xp22.33 & 354464 & 401509 & 47,0 & 3 dup & - & $6,13,16$ & 3 \\
\hline
\end{tabular}




\begin{tabular}{|c|c|c|c|c|c|c|c|}
\hline Xp22.33 & 784132 & 837452 & 53,3 & $2 \mathrm{del}$ & - & 3,16 & 2 \\
\hline Xp22.33 & 1378501 & 1818776 & 440,3 & 2 del/4 dup & $\begin{array}{l}\text { CSF2RA, IL3RA, } \\
\text { SLC25A6 }\end{array}$ & $1,3,5,11,15,16$ & 6 \\
\hline Xp22.33 & 2295258 & 2302145 & 6,9 & 2 del & DHRSX & 16,19 & 2 \\
\hline Xp22.31 & 6621971 & 6634382 & 12,4 & 2 dup & - & 16,23 & 2 \\
\hline Xp21.3 & 29111923 & 29117749 & 5,8 & $2 \mathrm{del}$ & IL1RAPL1 & 16,23 & 2 \\
\hline Xp11.22 & 53475174 & 53488727 & 13,6 & $2 \mathrm{del}$ & - & 1,16 & 2 \\
\hline $\mathrm{Xq23}$ & 115133388 & 115589080 & 455,7 & 5 del & SLC6A14 & $7,10,16,20,22$ & 5 \\
\hline $\mathrm{Xq26.1}$ & 129375241 & 129383116 & 7,9 & 4 del & ZNF280C & $8,13,14,23$ & 4 \\
\hline $\mathrm{Xq26.3}$ & 133642080 & 134947464 & 1305,4 & 3 del/1 dup & $\begin{array}{l}\text { DDX26B, CT45A1, } \\
\text { CT45A2, CT45A4, } \\
\text { CT45A3, СТ45A5 }\end{array}$ & $12,16,19$ & 3 \\
\hline $\mathrm{Xq26.3}$ & 134928992 & 134966528 & 37,5 & $1 \mathrm{del} / 5$ dup & $\begin{array}{l}\text { CT45A4, СТ45A5, } \\
\text { CT45A6 }\end{array}$ & $10,11,17,20,21,23$ & 6 \\
\hline Xq27.1 & 139493361 & 139806255 & 312,9 & $5 \mathrm{del} / 1 \mathrm{dup}$ & - & $2,3,5,11,15,16$ & 6 \\
\hline $\mathrm{Xq28}$ & 147317018 & 147325589 & 8,6 & $5 \mathrm{del}$ & - & $8,12,19,21,22$ & 5 \\
\hline $\mathrm{Xq} 28$ & 154918771 & 154952242 & 33,5 & $2 \mathrm{del}$ & - & 16,23 & 2 \\
\hline
\end{tabular}




\section{DISTRIBUIÇÃO GERAL DAS CNVS ENVOLVENDO GENES}

Do total de 406 CNVs detectadas no conjunto amostral, 269 CNVs (66,3\%) ocorreram em regiões contendo genes ou parte deles (Figura 8). Dessas, 47 CNVs possuíam genes descritos no OMIM. Em relação às variantes contendo micro RNAs (miRNA) ou pequenos RNAs nucleares (snoRNAs), foram encontradas 4 CNVs (1,5\%) (Tabela 9).

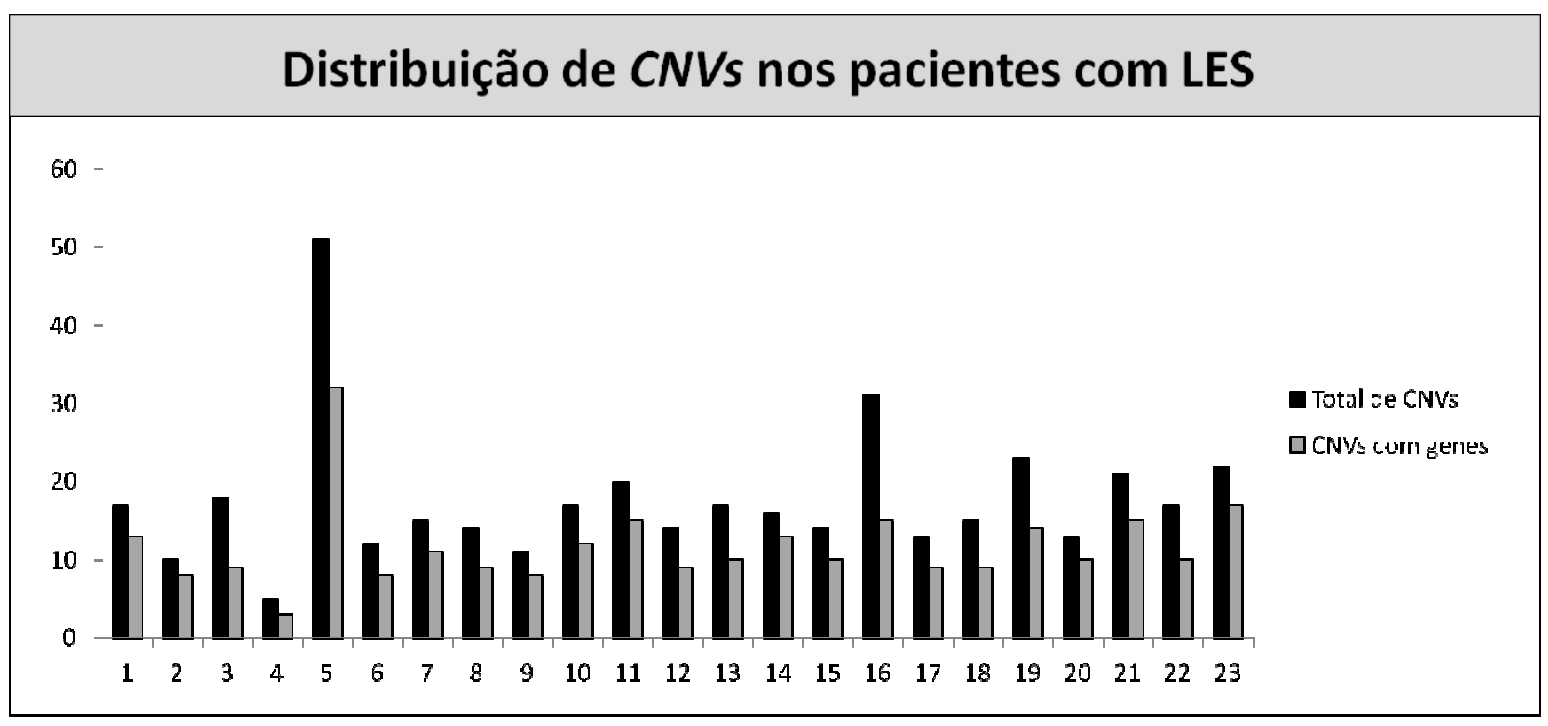

Figura 8. Distribuição do total de CNVs comparado àquelas que possuem genes nos pacientes com LES. 
Tabela 9. Distribuição geral das CNVs que possuem genes nos pacientes com LES.

\begin{tabular}{|c|c|c|c|c|}
\hline Paciente & Total de CNVs & $\begin{array}{l}\text { CNVs com } \\
\text { Genes }\end{array}$ & OMIM & sno/miRNA \\
\hline 1 & 17 & 13 & 1 & 1 \\
\hline 2 & 10 & 8 & 0 & 0 \\
\hline 3 & 18 & 9 & 4 & 0 \\
\hline 4 & 5 & 3 & 0 & 0 \\
\hline 5 & 51 & 32 & 13 & 0 \\
\hline 6 & 12 & 8 & 0 & 0 \\
\hline 7 & 15 & 11 & 1 & 1 \\
\hline 8 & 14 & 9 & 1 & 0 \\
\hline 9 & 11 & 8 & 0 & 0 \\
\hline 10 & 17 & 12 & 4 & 0 \\
\hline 11 & 20 & 15 & 2 & 0 \\
\hline 12 & 14 & 9 & 2 & 0 \\
\hline 13 & 17 & 10 & 1 & 0 \\
\hline 14 & 16 & 13 & 1 & 0 \\
\hline 15 & 14 & 10 & 2 & 0 \\
\hline 16 & 31 & 15 & 3 & 1 \\
\hline 17 & 13 & 9 & 0 & 0 \\
\hline 18 & 15 & 9 & 1 & 0 \\
\hline 19 & 23 & 14 & 4 & 0 \\
\hline 20 & 13 & 10 & 1 & 0 \\
\hline 21 & 21 & 15 & 1 & 1 \\
\hline 22 & 17 & 10 & 2 & 0 \\
\hline 23 & 22 & 17 & 3 & 0 \\
\hline Total & 406 & 269 & 47 & 4 \\
\hline
\end{tabular}

miRNA: micro RNA; snoRNA: pequenos RNAs nucleares. 


\section{CNVS COM GENES DESCRITOS NO OMIM}

A relação das CNVs encontradas na amostra de pacientes com LES e as condições patogênicas foi estabelecida em parte, considerando os genes previamente descritos no OMIM. Foram encontradas 35 CNVs com genes descritos no OMIM em 18 indivíduos (Tabela 10). 
Tabela 10. CNVs com genes descritos no OMIM.

\begin{tabular}{|c|c|c|c|c|}
\hline $\begin{array}{l}\text { Localização } \\
\text { genômica }\end{array}$ & Tipo & Genes & $D G V$ & Pacientes \\
\hline $1 q 21.3$ & deleção & FLG & $\operatorname{sim}$ & 5 \\
\hline $2 p 16.3$ & deleção & NRXN1 & não & 5 \\
\hline $2 q 33.1$ & deleção & BMPR2 & $\operatorname{sim}$ & 10 e 19 \\
\hline $3 p 12.2$ & deleção & GBE1 & não & 5 \\
\hline $3 p 12.3$ & deleção & ROBO2 & não & 5 \\
\hline $3 q 12.2$ & duplicação & GPR128, TFG & $\operatorname{sim}$ & 3 \\
\hline $3 q 28$ & deleção & TP63 & $\operatorname{sim}$ & $3,12,12$ e 23 \\
\hline $6 p 21.31$ & duplicação & FKBP5 & $\operatorname{sim}$ & 15 \\
\hline $6 q 12$ & deleção & EYS & $\operatorname{sim}$ & 3 e 5 \\
\hline $6 q 25.1$ & deleção & ESR1 & $\operatorname{sim}$ & 10 \\
\hline $7 q 31.1$ & deleção & FOXP2 & não & 5 \\
\hline $7 q 34$ & deleção & PRSS1, TRY6, PRSS2 & $\operatorname{sim}$ & 19 \\
\hline $7 q 35$ & deleção & CNTNAP2 & não & 10 \\
\hline 8p22 & deleção & TUSC3 & $\operatorname{sim}$ & 5 \\
\hline $8 q 13.3$ & deleção & EYA1 & $\operatorname{sim}$ & 13 \\
\hline $8 q 24.22$ & deleção & TG & $\operatorname{sim}$ & 18 \\
\hline $12 p 12.1$ & duplicação & LDHB, KCNJ8, ABCC9, CMAS, ST8SIA1 & $\operatorname{sim}$ & 11 \\
\hline $12 q 21.33$ & deleção & KERA & não & 5 \\
\hline $13 q 31.3$ & deleção & GPC6 & não & 5 \\
\hline $15 q 15.3$ & deleção & CKMT1B, STRC, CATSPER2 & $\operatorname{sim}$ & 5 \\
\hline $16 p 13.3$ & duplicação & $\begin{array}{l}\text { OR1F1, OR1F2P, ZNF200, MEFV, } \\
\text { FLJ39639 }\end{array}$ & $\operatorname{sim}$ & 5 \\
\hline $19 q 13.2$ & deleção & CYP2A6, CYP2A7 & $\operatorname{sim}$ & 1,19 e 23 \\
\hline $19 q 13.2$ & deleção & CYP2A6 & $\operatorname{sim}$ & 7 e 12 \\
\hline $19 q 13.42$ & deleção & $\begin{array}{l}\text { KIR3DP1, KIR2DL1, KIR2DL4, KIR3DL1, } \\
\text { KIR2DS4 }\end{array}$ & $\operatorname{sim}$ & 3 \\
\hline $22 q 12.1$ & duplicação & CHEK2 & $\operatorname{sim}$ & 8 \\
\hline $22 q 12.3$ & deleção & LARGE & $\operatorname{sim}$ & 21 \\
\hline $22 q 13.33$ & deleção & SHANK3 & $\operatorname{sim}$ & 11 \\
\hline Xp11.23 & deleção & CLCN5 & $\operatorname{sim}$ & 16 \\
\hline Xp21.1 & deleção & DMD & não & 19 \\
\hline Xp21.3 & deleção & IL1RAPL1 & $\operatorname{sim}$ & 16,22 e 23 \\
\hline Xp22.2 & deleção & MID1 & não & 10 \\
\hline Xp22.33 & duplicação & CSF2RA, IL3RA, SLC25A6 & $\operatorname{sim}$ & 15 \\
\hline Xq23 & deleção & SLC6A14 & não & 20 e 22 \\
\hline Xq26.3 & duplicação & $\mathrm{ZIC3}$ & não & 16 \\
\hline Xq28 & deleção & OPN1LW & $\operatorname{sim}$ & 5 \\
\hline
\end{tabular}




\section{CNVS NÃO DESCRITAS NO DGV}

As CNVs foram avaliadas quanto à descrição em banco de dados de variantes estruturais do genoma. Com relação às CNVs não catalogadas no banco de dados $D G V$, isto é, não descritas em indivíduos controle, foram encontradas 39 em 14 pacientes (Tabela 11). A maioria apresentava genes, totalizando 27 CNVs (69,2\%). Destes, 11 genes foram previamente descritos em condições patogênicas e catalogados no OMIM, e 10 foram descritos em banco de dados de regiões constitutivas do genoma, o ISCA. Das 39 CNVs não descritas no $D G V, 36$ (92,3\%) ocorreram uma única vez e apenas $3(7,7 \%)$ foram recorrentes. 
Tabela 11. CNVs não descritas no $D G V$.

\begin{tabular}{|c|c|c|c|c|c|c|}
\hline Localização genômica & Tipo & Tamanho (Kb) & Genes & OMIM & ISCA & Pacientes \\
\hline $1 p 31.3$ & deleção heterozigótica & 12,8 & - & não & $\operatorname{sim}$ & 5 \\
\hline $1 q 24.2$ & deleção heterozigótica & 29,7 & MPZL1 & não & não & 6 \\
\hline $2 p 16.3$ & deleção heterozigótica & 14,6 & NRXN1 & $\operatorname{sim}$ & $\operatorname{sim}$ & 5 \\
\hline $2 \mathrm{p} 22.2$ & deleção heterozigótica & 32,0 & VIT & não & não & 20 \\
\hline $3 p 12.2$ & deleção heterozigótica & 17,5 & GBE1 & $\operatorname{sim}$ & não & 5 \\
\hline $3 p 12.3$ & deleção heterozigótica & 11,8 & ROBO2 & $\operatorname{sim}$ & não & 5 \\
\hline 3p14.1 & duplicação heterozigótica & 77,6 & MAGI1 & não & não & 16 \\
\hline $3 q 13.33$ & deleção heterozigótica & 15,4 & GTF2E1 & não & não & 21 \\
\hline $4 p 12$ & deleção heterozigótica & 21,3 & GABRG1 & não & não & 16 \\
\hline $4 q 35.1$ & duplicação heterozigótica & 60,7 & - & não & não & 1 \\
\hline $5 p 15.31$ & deleção heterozigótica & 2,5 & FLJ33360 & não & não & 8 \\
\hline $5 q 33.2$ & deleção heterozigótica & 44,2 & - & não & não & 5 \\
\hline $6 q 12$ & deleção heterozigótica & 18,0 & EYS & $\operatorname{sim}$ & não & 5 \\
\hline $6 q 14.1$ & deleção heterozigótica & 19,8 & - & não & não & 5 \\
\hline $6 q 16.1$ & deleção heterozigótica & 26,2 & EPHA7 & não & não & 5 \\
\hline 7p21.3 & deleção heterozigótica & 25,3 & $\mathrm{NXPH} 1$ & não & não & 5 \\
\hline $7 q 31.1$ & deleção heterozigótica & 6,3 & FOXP2 & $\operatorname{sim}$ & $\operatorname{sim}$ & 5 \\
\hline $7 q 35$ & deleção heterozigótica & 8,8 & CNTNAP2 & $\operatorname{sim}$ & $\operatorname{sim}$ & 10 \\
\hline $9 q 33.1$ & deleção heterozigótica & 12,3 & DBC1 & não & não & 5 \\
\hline $11 q 14.1$ & deleção heterozigótica & 24,1 & DLG2 & não & não & 5 \\
\hline $11 q 25$ & deleção heterozigótica & 16,1 & - & não & não & 5 \\
\hline $12 q 21.33$ & deleção heterozigótica & 12,1 & KERA & $\operatorname{sim}$ & não & 5 \\
\hline $13 q 31.3$ & deleção heterozigótica & 8,1 & GPC5 & não & $\operatorname{sim}$ & 5 \\
\hline $13 q 31.3$ & deleção heterozigótica & 8,9 & GPC6 & $\operatorname{sim}$ & $\operatorname{sim}$ & 5 \\
\hline $14 q 23.3$ & duplicação heterozigótica & 37,4 & GPHN & não & não & 21 \\
\hline $18 q 12.2$ & deleção heterozigótica & 68,4 & - & não & não & 22 \\
\hline $20 p 12.1$ & deleção homozigótica & 23,2 & MACROD2 & não & não & 17 \\
\hline Xp21.1 & deleção heterozigótica & 1,2 & DMD & $\operatorname{sim}$ & $\operatorname{sim}$ & 19 \\
\hline Xp22.2 & deleção heterozigótica & 2,1 & MID1 & $\operatorname{sim}$ & $\operatorname{sim}$ & 10 \\
\hline $\mathrm{Xq22.3}$ & deleção heterozigótica & 6,1 & MID2 & não & $\operatorname{sim}$ & 14 \\
\hline Xq23 & deleção heterozigótica & 3,2 & - & não & não & 16 \\
\hline $\mathrm{Xq24}$ & deleção heterozigótica & 11,0 & - & não & não & 19 \\
\hline Xq26.3 & deleção heterozigótica & 0,6 & - & não & não & 21 \\
\hline $\mathrm{Xq} 26.3$ & duplicação heterozigótica & 9,0 & - & não & não & 23 \\
\hline Xq26.3 & duplicação homozigótica & 29,2 & $\mathrm{ZIC3}$ & $\operatorname{sim}$ & $\operatorname{sim}$ & 16 \\
\hline Xq26.1 & deleção heterozigótica & 1,2 & ZNF280C & não & não & 8 e 13 \\
\hline$X q 26.1$ & deleção heterozigótica & 7,7 & ZNF280C & não & não & 14 e 23 \\
\hline Xq26.3 & deleção heterozigótica & 12 & - & não & não & 16 e 19 \\
\hline Xq27.1 & deleção heterozigótica & 1,8 & - & não & não & 8 \\
\hline
\end{tabular}




\section{CNVS NÃO DESCRITAS EM BANCO DE DADOS}

A existência de CNVs catalogadas foi avaliada considerando os bancos de dados de variantes estruturais disponiveis online: DECIPHER, ISCA e DGV. Foram encontradas nove CNVs não descritas em bancos de dados em um total de cinco indivíduos (Tabela 12). O paciente cinco apresentou cinco das nove $C N V$ s identificadas. A localização genômica e as características das $C N V s$ não descritas podem ser observadas na Figura 9.

Tabela 12. CNVs não descritas em banco de dados.

\begin{tabular}{llllll}
\hline $\begin{array}{c}\text { Localização } \\
\text { genômica }\end{array}$ & \multicolumn{1}{c}{ Tipo } & $\begin{array}{c}\text { Tamanho } \\
\mathbf{( K b )}\end{array}$ & Genes & OMIM & Pacientes \\
\hline $\mathbf{4 p 1 2}$ & deleção heterozigótica & 21,3 & GABRG1 & não & 16 \\
$\mathbf{4 q 3 5 . 1}$ & duplicação heterozigótica & 60,7 & - & não & 1 \\
$\mathbf{5 q 3 3 . 2}$ & deleção heterozigótica & 44,2 & - & não & 5 \\
$\mathbf{6 q 1 2}$ & deleção heterozigótica & 18,0 & EYS & sim & 5 \\
$\mathbf{9 q 3 3 . 1}$ & deleção heterozigótica & 12,3 & DBC1 & não & 5 \\
$\mathbf{1 1 q 1 4 . 1}$ & deleção heterozigótica & 24,1 & DLG2 & não & 5 \\
$\mathbf{1 1 q 2 5}$ & deleção heterozigótica & 16,1 & - & não & 5 \\
$\mathbf{1 8 q 1 2 . 2}$ & deleção heterozigótica & 68,4 & - & não & 22 \\
$\mathbf{1 4 q 2 3 . 3}$ & duplicação heterozigótica & 37,4 & GPHN & não & 21 \\
\hline
\end{tabular}




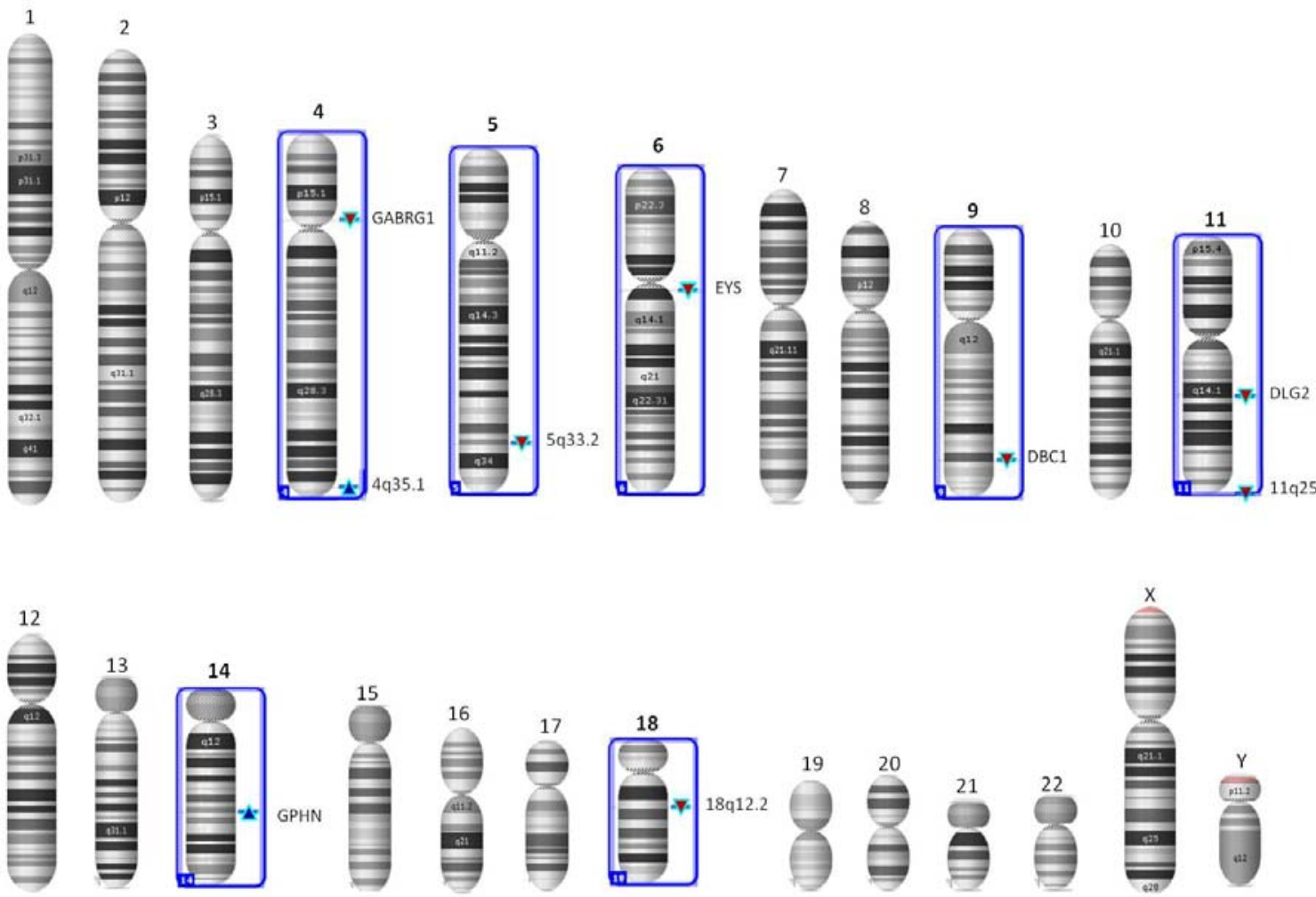

Figura 9. Localização genômica das CNVs não descritas em banco de dados. Os triângulos vermelhos indicam segmentos deletados, enquanto que os azuis indicam os segmentos duplicados.

\section{CNVS EM GENES RELACIONADOS COM AUTOIMUNIDADE}

Com o auxílio da ferramenta Cytoregions do programa ChAS foi possivel identificar regiões no genoma relacionadas com autoimunidade. Das 406 CNVs identificadas no conjunto amostral, foram encontradas seis CNVs em genes previamente relacionados com LES e uma $C N V$ associada a Diabetes Mellitus autoimune tipo 1 (DM1), totalizando sete CNVs (Figura 10). Destas, duas foram recorrentes e cinco foram encontradas uma única vez na amostra. (Tabela 13). Todos os genes encontrados nessas regiões foram pesquisados em bases de dados Ensembl Genome Browser e NCBI, para análise de sua função e padrão de expressão. 
Tabela 13. CNVs em genes relacionados com autoimunidade.

\begin{tabular}{llllll}
\hline $\begin{array}{c}\text { Localização } \\
\text { genômica }\end{array}$ & Tipo & $\begin{array}{c}\text { Tamanho } \\
(\mathbf{K b})\end{array}$ & $\begin{array}{c}\text { Genes de } \\
\text { interesse }\end{array}$ & \multicolumn{1}{c}{ Relevância } & Pacientes \\
\hline $\mathbf{1 q 3 1 . 3}$ & Deleção & 49,2 & CFHR4 & Gene associado a LES & 7 \\
$\mathbf{1 q 3 1 . 3}$ & Deleção & 22,8 & CFHR5 & Gene associado a LES & 12 \\
$\mathbf{2 q 3 2 . 2}$ & Deleção & 17,8 & STAT4 & Gene associado a LES & 2 \\
$\mathbf{6 p 2 1 . 3 2}$ & Deleção & 11,9 & HLA-DPB2 & Gene associado a LES & 1 e 5 \\
$\mathbf{8 q 1 1 . 2 1}$ & Deleção & 0,4 & SNTG1 & CNV associada a diabetes tipo 1 & 21 \\
$\mathbf{X p 2 2 . 3 3}$ & Deleção & 9,9 & IL3RA & Gene associado a autoimunidade & 11 \\
$\mathbf{X q 2 8}$ & Duplicação & 0,9 & MECP2 & Gene associado a LES & $3,16,17,18$, \\
& & & & & 21,23 e 25 \\
\hline
\end{tabular}
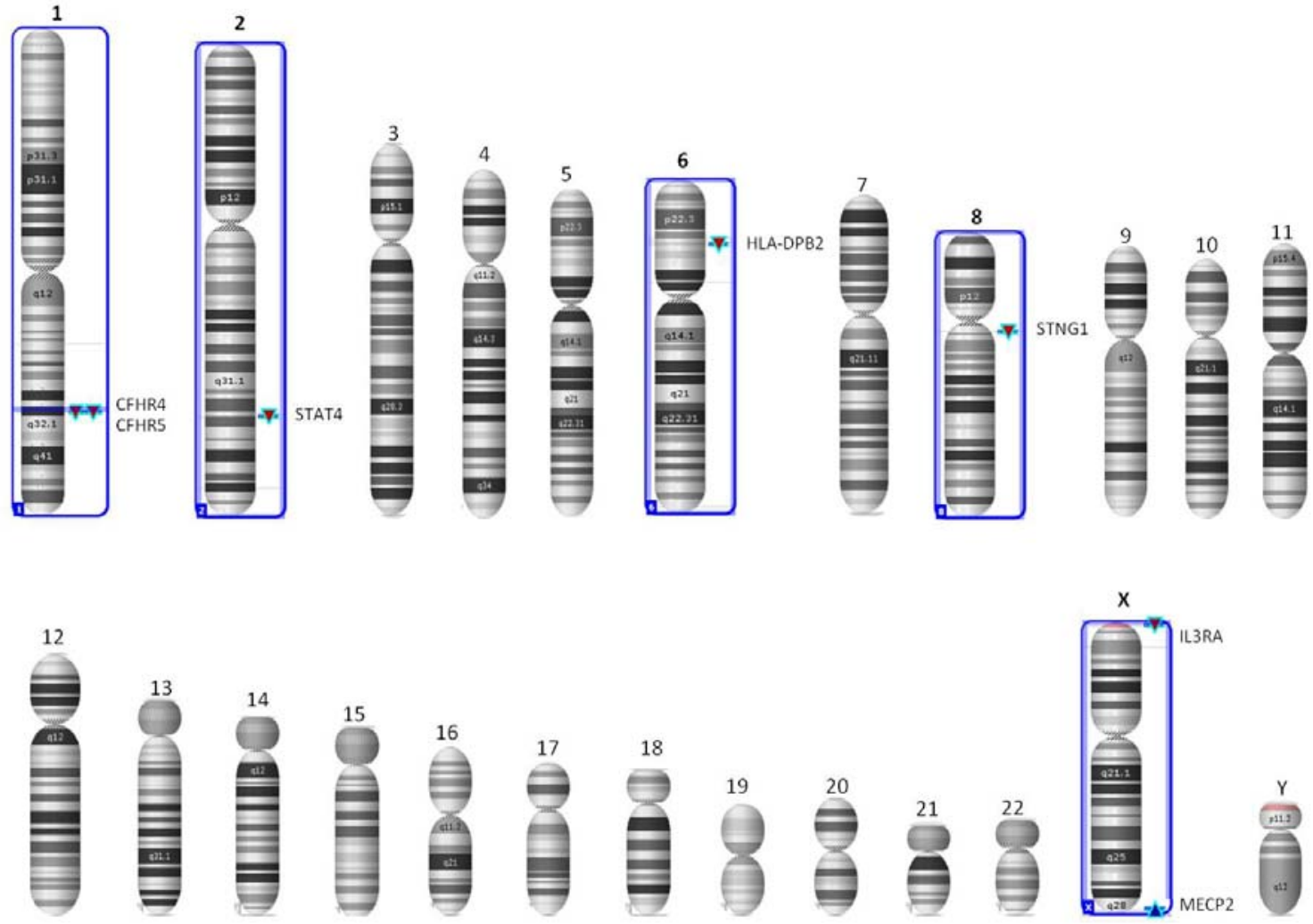

Figura 10. Localização genômica das CNVs relacionadas com autoimunidade.Os triângulos vermelhos indicam segmentos deletados, enquanto que os azuis indicam os segmentos duplicados. 


\section{CNVS COMUNS EM GENES RELACIONADOS COM AUTOIMUNIDADE}

De forma similar à identificação de $C N V$ s relacionadas com autoimunidade, a ferramenta Cytoregions proporcionou a detecção de CNVs comuns, isto é, com frequência maior do que $5 \%$ previamente descritas em associação com doenças autoimunes (Tabela 14).

Os processos biológicos dos genes envolvidos com autoimunidade foram classificados em dez vias de acordo com a ferramenta disponível online PANTHER Classification System (MI et al., 2010), incluindo apoptose, comunicação celular e processos sistêmicos (Figura 11).

Tabela 14. CNVs comuns presentes no conjunto amostral.

\begin{tabular}{|c|c|c|c|c|c|c|c|}
\hline $\begin{array}{l}\text { Localização } \\
\text { genômica }\end{array}$ & Tipo & $\begin{array}{l}\text { Genes } \\
\text { de interesse }\end{array}$ & OMIM & $D G V$ & ISCA & Pacientes & $\begin{array}{l}\text { Número de } \\
\text { pacientes }\end{array}$ \\
\hline $4 q 13.2$ & deleção & UGT2B15 & não & $\operatorname{sim}$ & não & $5,15,19$ e 22 & 4 \\
\hline 8p11.22 & deleção & ADAM3A & não & $\operatorname{sim}$ & não & $\begin{array}{l}1,2,4,5,6,7 \\
9,10,11,12 \\
13,14,15,16 \\
17,18,20,21 \mathrm{e} \\
22\end{array}$ & 19 \\
\hline $17 q 21.31$ & duplicação & KIAA1267 & não & $\operatorname{sim}$ & não & $\begin{array}{l}1,4,5,6,7,8 \\
9,12,14 \text { e } 17\end{array}$ & 10 \\
\hline
\end{tabular}




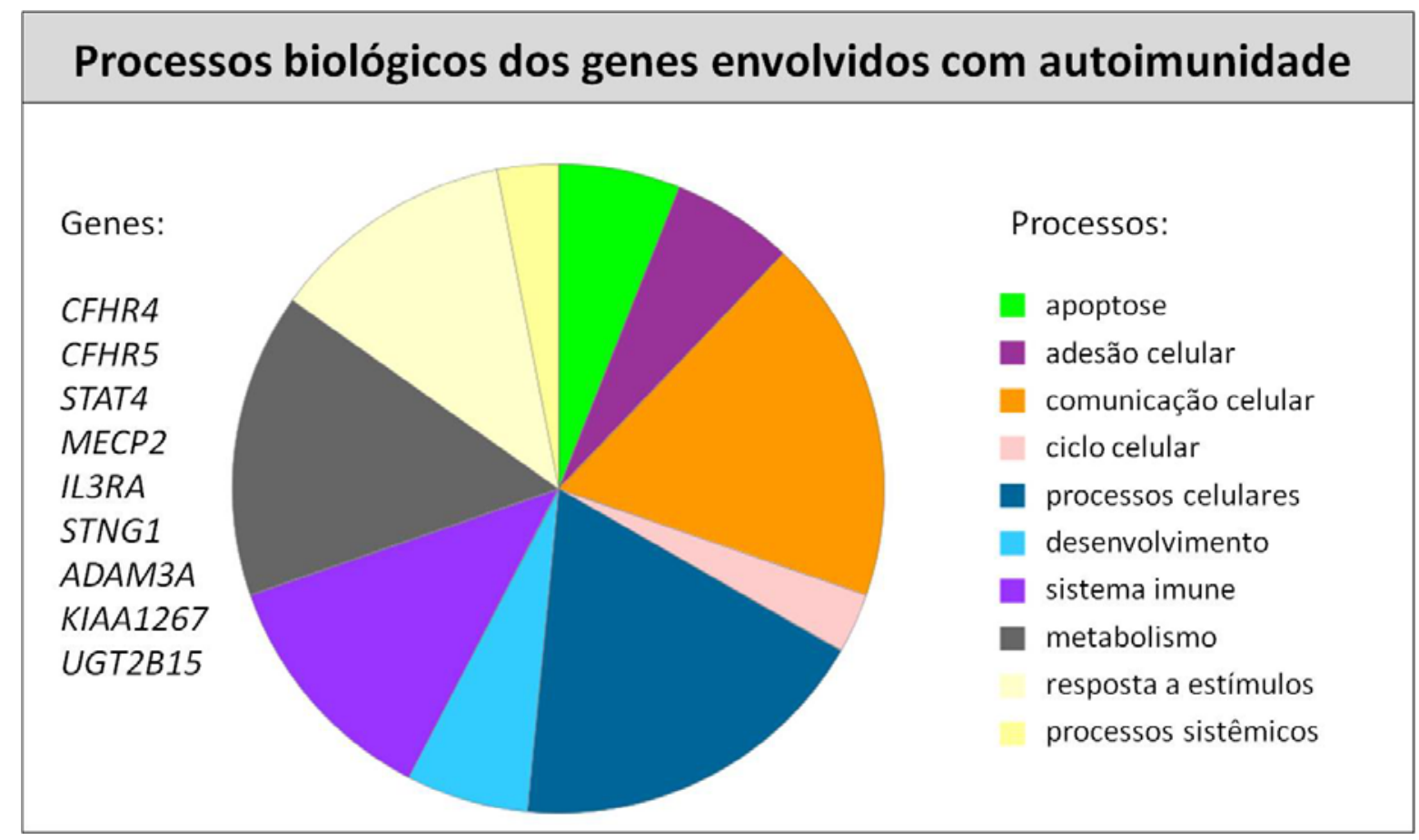

Figura 11. Processos biológicos dos genes envolvidos com autoimunidade presentes nas CNVs encontradas nos pacientes com LES. PANTHER Classification System (MI et al., 2010). 


\section{DISCUSSÃO}

\section{CASUÍSTICA}

Considerando as 23 amostras de pacientes portadores de LES estudadas, houve predominância de mulheres (18 mulheres e 5 homens). Mesmo a casuística sendo pequena, a prevalência de mulheres acometidas pelo LES está em concordância com os aspectos epidemiológicos da doença (MAIDHOF; HILAS, 2012).

Os critérios de inclusão (presença de nefrite lúpica, lesões cutâneas, algum tipo de infecção, manifestações neurológicas) aplicados favorecem a seleção de casos mais severos que, por isso, dão mais segurança aos estudos genéticos, pois diminuem a chance de casos não LES em nossa amostra. Todas as mulheres atenderam aos critérios e os homens, somente aos três primeiros, também de acordo com a observação clínica de que o sexo feminino é mais sensivel, em incidência e severidade, a LES.

\section{QUALIDADE DOS DADOS}

Somente um chip foi descartado das análises, pois apresentou problema de fabricação, constatado na etapa final dos experimentos de $a G H$ quando se percebeu que o lacre que assegura a permanência da solução dentro do chip não vedava completamente, comprometendo a leitura posterior. Três chips não atingiram, para um dos parâmetros de qualidade, os valores de limiar, mas esta diferença, diante dos resultados das análises posteriores, demonstrou-se insignificante. Além disso, os elevados índices de qualidade em todos os parâmetros das lâminas restantes conferem alto grau de confiabilidade dos resultados obtidos. 


\section{PROPORÇÃO VARIÁVEL DO GENOMA}

As CNVs contribuem para a diversidade genética e fenotípica humana. No entanto, a distribuição dessas variantes na população geral permanece largamente inexplorada (ITSARA et al., 2009).

A elaboração por Redon et al. (2006) do primeiro mapa abrangente de CNVs, baseada na análise de 270 indivíduos do projeto HapMap (GIBBS et al., 2003), teve papel chave no campo da descoberta de CNVs. A pesquisa foi realizada utilizando a combinação de duas plataformas, aCGH (Whole Genome Tile Path array) e SNP array (Affymetrix GeneChip Human Mapping 500K), que proporcionaram cobertura de aproximadamente $90 \%$ do genoma e a estimativa da proporção variável do genoma, definida como a soma média (aproximadamente $340 \mathrm{Mb}$ ) do número de bases perdidas por deleção ou acrescentadas por duplicação, em $12 \%$ do genoma.

Ao combinar informações de sondas de SNPs e CNVs em uma versão mais recente do SNP array (Affymetrix Genome-Wide Human SNP Array 6.0), McCarroll et al. (2008) desenvolveram um mapa de CNVs em que os limites das CNVs foram melhor estabelecidos. Este estudo forneceu um novo ponto de referência ao constatar que a maioria das CNVs descritas anteriormente nos 270 individuos do projeto HapMap eram de cinco a 15 vezes menores do que inicialmente relatadas por meio de abordagens com resolução inferior (MCCARROLL, 2008; REDON et al., 2006).

Conforme esperado, plataformas de microarranjo de alta densidade recentemente desenvolvidas apresentam maior resolução em detectar pequenas variantes. Entre elas, a tecnologia CytoScan $\mathrm{HD}^{\mathrm{TM}}$, aplicada ao presente trabalho, é capaz de detectar cerca de 2,6 milhões de CNVs e 750 mil SNPs, proporcionando resultados mais confiáveis com alta resolução.

Esta metodologia permitiu observar distribuição unimodal da contagem de CNVs, com média de 18 variantes por indivíduo (Tabela 4), e soma média dos segmentos deletados/duplicados igual a $1796 \mathrm{~kb}$, que corresponde a uma proporção variável de 0,06\% do genoma (Tabela 15). Esses achados se aproximam do que foi relatado por Vogler et al. (2010) em que a média foi de 7 
CNVs por indivíduo e soma média da variação de $540 \mathrm{~kb}$, aproximadamente 0,02\% do genoma, mas contrastam com os valores relatados por Redon et al., (2006) e McCarrol et al. (2008). Embora não exista um consenso sobre a proporção variável do genoma, pode-se observar que existe uma tendência de diminuição das estimativas dessa porcentagem, paralela ao desenvolvimento de plataformas com maior resolução e capacidade de detecção de CNVs.

Tabela 15. Proporção variável do genoma representada pelas CNVs nos pacientes com LES.

\begin{tabular}{cllllll}
\hline Paciente & \multicolumn{2}{c}{$\begin{array}{c}\text { Genoma } \\
\text { duplicado }\end{array}$} & \multicolumn{2}{c}{$\begin{array}{c}\text { Genoma } \\
\text { Deletado }\end{array}$} & $\begin{array}{c}\text { Porção variável do } \\
\text { genoma total }\end{array}$ \\
\hline $\mathbf{1}$ & $969 \mathrm{~kb}$ & $0,03 \%$ & $350 \mathrm{~kb}$ & $0,01 \%$ & $1319 \mathrm{~kb}$ & $0,04 \%$ \\
$\mathbf{2}$ & $441 \mathrm{~kb}$ & $0,01 \%$ & $608 \mathrm{~kb}$ & $0,02 \%$ & $1049 \mathrm{~kb}$ & $0,03 \%$ \\
$\mathbf{3}$ & $852 \mathrm{~kb}$ & $0,03 \%$ & $861 \mathrm{~kb}$ & $0,03 \%$ & $1714 \mathrm{~kb}$ & $0,06 \%$ \\
$\mathbf{4}$ & $433 \mathrm{~kb}$ & $0,01 \%$ & $219 \mathrm{~kb}$ & $0,01 \%$ & $652 \mathrm{~kb}$ & $0,02 \%$ \\
$\mathbf{5}$ & $1364 \mathrm{~kb}$ & $0,05 \%$ & $3670 \mathrm{~kb}$ & $0,12 \%$ & $5034 \mathrm{~kb}$ & $0,17 \%$ \\
$\mathbf{6}$ & $1695 \mathrm{~kb}$ & $0,06 \%$ & $644 \mathrm{~kb}$ & $0,02 \%$ & $2339 \mathrm{~kb}$ & $0,08 \%$ \\
$\mathbf{7}$ & $1694 \mathrm{~kb}$ & $0,06 \%$ & $1096 \mathrm{~kb}$ & $0,04 \%$ & $2790 \mathrm{~kb}$ & $0,09 \%$ \\
$\mathbf{8}$ & $509 \mathrm{~kb}$ & $0,02 \%$ & $265 \mathrm{~kb}$ & $0,01 \%$ & $775 \mathrm{~kb}$ & $0,03 \%$ \\
$\mathbf{9}$ & $1774 \mathrm{~kb}$ & $0,06 \%$ & $536 \mathrm{~kb}$ & $0,02 \%$ & $2311 \mathrm{~kb}$ & $0,08 \%$ \\
$\mathbf{1 0}$ & $1083 \mathrm{~kb}$ & $0,04 \%$ & $440 \mathrm{~kb}$ & $0,01 \%$ & $1523 \mathrm{~kb}$ & $0,05 \%$ \\
$\mathbf{1 1}$ & $1495 \mathrm{~kb}$ & $0,05 \%$ & $625 \mathrm{~kb}$ & $0,02 \%$ & $2121 \mathrm{~kb}$ & $0,07 \%$ \\
$\mathbf{1 2}$ & $864 \mathrm{~kb}$ & $0,03 \%$ & $477 \mathrm{~kb}$ & $0,02 \%$ & $1341 \mathrm{~kb}$ & $0,04 \%$ \\
$\mathbf{1 3}$ & $980 \mathrm{~kb}$ & $0,03 \%$ & $1394 \mathrm{~kb}$ & $0,05 \%$ & $2374 \mathrm{~kb}$ & $0,08 \%$ \\
$\mathbf{1 4}$ & $1465 \mathrm{~kb}$ & $0,05 \%$ & $876 \mathrm{~kb}$ & $0,03 \%$ & $2342 \mathrm{~kb}$ & $0,08 \%$ \\
$\mathbf{1 5}$ & $575 \mathrm{~kb}$ & $0,02 \%$ & $563 \mathrm{~kb}$ & $0,02 \%$ & $1138 \mathrm{~kb}$ & $0,04 \%$ \\
$\mathbf{1 6}$ & $809 \mathrm{~kb}$ & $0,03 \%$ & $927 \mathrm{~kb}$ & $0,03 \%$ & $1736 \mathrm{~kb}$ & $0,06 \%$ \\
$\mathbf{1 7}$ & $1291 \mathrm{~kb}$ & $0,04 \%$ & $394 \mathrm{~kb}$ & $0,01 \%$ & $1685 \mathrm{~kb}$ & $0,06 \%$ \\
$\mathbf{1 8}$ & $418 \mathrm{~kb}$ & $0,01 \%$ & $792 \mathrm{~kb}$ & $0,03 \%$ & $1209 \mathrm{~kb}$ & $0,04 \%$ \\
$\mathbf{1 9}$ & $1122 \mathrm{~kb}$ & $0,04 \%$ & $1142 \mathrm{~kb}$ & $0,04 \%$ & $2264 \mathrm{~kb}$ & $0,08 \%$ \\
$\mathbf{2 0}$ & $75 \mathrm{~kb}$ & $0,00 \%$ & $451 \mathrm{~kb}$ & $0,02 \%$ & $526 \mathrm{~kb}$ & $0,02 \%$ \\
$\mathbf{2 1}$ & $1164 \mathrm{~kb}$ & $0,04 \%$ & $639 \mathrm{~kb}$ & $0,02 \%$ & $1803 \mathrm{~kb}$ & $0,06 \%$ \\
$\mathbf{2 2}$ & $1041 \mathrm{~kb}$ & $0,03 \%$ & $708 \mathrm{~kb}$ & $0,02 \%$ & $1749 \mathrm{~kb}$ & $0,06 \%$ \\
$\mathbf{2 3}$ & $1073 \mathrm{~kb}$ & $0,04 \%$ & $434 \mathrm{~kb}$ & $0,01 \%$ & $1506 \mathrm{~kb}$ & $0,05 \%$ \\
\hline Soma $\mathbf{m e ́} \% \mathrm{kia}$ & $\mathbf{1 0 0 8} \mathrm{kb}$ & $\mathbf{0 , 0 3 \%}$ & $\mathbf{7 8 7} \mathbf{k b}$ & $\mathbf{0 , 0 3} \%$ & $\mathbf{1 7 9 6} \mathrm{kb}$ & $\mathbf{0 , 0 6 \%}$ \\
\hline & & & & & & \\
\hline
\end{tabular}




\section{PERFIL DE CNVS NO GENOMA}

Para que a análise padrão dos resultados encontrados minimizasse a detecção de falso-positivos, o número mínimo de marcadores para a identificação de $C N V$ s foi maior para duplicações do que para deleções, 50 e 25 , respectivamente. A exigência de um número maior de marcadores para a detecção de duplicações apresenta um viés que é neutralizado quando se considera o fato de que as duplicações de forma geral envolvem segmentos genômicos maiores do que as deleções e, portanto, cobrem regiões que possuem usualmente mais marcadores do que o limite aqui determinado (CHOY et al., 2010).

Do total de 406 CNVs detectadas, 311 corresponderam a deleções (77\%) e 95 a duplicações (23\%). Como esperado, foram encontradas menos CNVs em homozigose do que em heterozigose, 31 e 375, respectivamente (Tabela 4) estando de acordo com outros trabalhos (SHARP et al., 2005; TUZUN et al., 2005).

A distribuição de tamanho das CNVs mostrou que as faixas de tamanho mais comuns, observadas nos pacientes com LES, foram de CNVs entre $10 \mathrm{e}$ $100 \mathrm{~kb}$ e entre 100 e $450 \mathrm{~kb}$, respectivamente (Tabela 5). Esses dados contrastam com as estimativas do DGV (Database of Genomic Variants, 2013) nas quais a faixa de tamanho mais comum das variantes catalogadas no banco de dados é a de CNVs menores, entre 1 e $10 \mathrm{~kb}$.

Na literatura, estima-se que 65 a $80 \%$ dos indivíduos tem pelo menos uma $C N V$ com menos de $100 \mathrm{~kb}$ de tamanho, 5 a $10 \%$ apresentam uma $C N V$ com mais de $450 \mathrm{~kb}$ e que apenas $1 \%$ possuem $C N V$ s maiores do que $1 \mathrm{Mb}$ (ITSARA et al., 2009; VOGLER et al., 2010). Em contrapartida, os resultados obtidos pela distribuição de CNVs na nossa amostra demonstraram números mais elevados em relação às CNVs menores do que $100 \mathrm{~kb}$ e maiores do que $450 \mathrm{~kb}$, visto que todos os pacientes apresentaram CNVs menores do que 100 $\mathrm{kb}$, e a maioria deles (16 pacientes) apresentou uma $C N V$ maior do que 450 $\mathrm{kb}$ (Tabela 6). Parte dessas $C N V s$ foi encontrada em mais de um paciente, caracterizando-se como comuns na amostragem aqui estudada. 
Embora o tamanho de uma $C N V$ por si só não possa ser usado como preditor de patogenicidade (ITSARA et al., 2009), as diferenças encontradas no tamanho das CNVs nos pacientes com LES em relação à literatura e ao principal banco de dados de variantes estruturais, o $D G V$, sugere que grandes CNVs podem estar envolvidas na etiologia do LES.

\section{RECORRÊNCIA DE CNVS}

Do total de 406 CNVs detectadas, 152 foram de ocorrência única $(37,5 \%)$ e 254 foram recorrentes entre os pacientes analisados (62,5\%) (Tabela 7). Este relato está de acordo com o que foi encontrado por Shaikh et al. (2009) em que a maioria das CNVs detectadas em amostra de individuos controle foi classificada como não-única, recorrentes em mais de um indivíduo não relacionado.

Embora tenham sido encontradas CNVs idênticas umas às outras, compartilhadas entre dois ou mais pacientes, em geral, a sobreposição das $C N V s$ recorrentes não é total. A maioria das CNVs recorrentes apresenta pontos de quebra distintos, ou seja, apresenta o mesmo início, mas varia no término, e vice-versa, ou ainda, não compartilham posições iniciais e finais, porém se sobrepõem em mais de $90 \%$ da sequência. Dessa forma, as CNVs recorrentes são comumente categorizadas em CNVRs, que representam a região de CNVs que se sobrepõe entre os individuos. No presente estudo, foram descritas 59 CNVRs, que englobaram as 254 CNVs recorrentes (Tabela 7).

O fato da existência de $C N V$ s idênticas ser incomum pode ser reflexo da formação de CNVs ocorrer com alta taxa de mutação. Estima-se que a taxa de mutação locus-específica de CNVs é de $1,7 \times 10^{-6}$ a $1,0 \times 10^{-4}$ por locus (LUPSKI, 2007; VAN OMMEN, 2005), enquanto que a taxa de mutação de SNPs por geração é $1,8-2,5 \times 10^{-8}$ por par de base por geração (KONDRASHOV, 2002; NACHMAN; CROWELL, 2000). Isto revela uma magnitude de geração de $C N V$ s de 100 a 10 mil vezes maior do que a taxa de substituição de nucleotídeos. Além disso, diferente da taxa de mutação de 
SNPS que é relativamente constante, as taxas de mutação de CNVs podem variar amplamente em diferentes loci, o que provavelmente reflete diferenças nos mecanismos de formação das CNVs e na arquitetura genômica local ou regional susceptivel à instabilidade genômica (ZHANG et al., 2009).

\section{RELEVÂNCIA FUNCIONAL DAS CNVS IDENTIFICADAS}

A análise genética de LES durante várias décadas, incluindo uma série de recentes estudos de associação genômica em larga escala, revelou mais de 30 loci de suscetibilidade à doença (MUELLER et al., 2013).

As pesquisas realizadas com CNVs e LES até o presente momento englobaram a análise pontual das variantes (MORRIS et al., 2010; WU et al., 2008) em que foram relatadas principalmente CNVs nos genes FCGR3B (MCKINNEY et al., 2010) e C4 (YANG, Y. et al., 2007), cujo baixo número de cópias foi associado com aumento da susceptibilidade a LES. No presente trabalho, não foram encontradas CNVs em tais genes. Entretanto, descrevemos, pela primeira vez, CNVs em outros cinco genes previamente associados com LES: CFHR4, CFHR5, STAT4, MECP2 e HLA-DPB2 (Figura 10, Tabela 13).

O LES é uma doença autoimune poligênica que está associada com aumento da ativação do complemento. As variantes de genes que codificam o fator $\mathrm{H}$ regulador do complemento $(\mathrm{CFH})$ e cinco proteínas relacionadas com CFH (CFHR1-CFHR5) dentro do locus 1q32, podem contribuir para a desregulação da ativação do complemento, predispondo ao desenvolvimento de LES (ZHAO, J. et al., 2011).

No nosso estudo, encontramos duas deleções únicas em dois pacientes, uma de $49 \mathrm{~kb}$ e outra de $23 \mathrm{~kb}$ nos genes CFHR4 e CFHR5, respectivamente. Funcionalmente, o gene CFHR4 tem papel-chave na regulação do complemento. A proteína $C F H R 4$ se liga a um forma pentamérica da proteína C-reativa (pCRP) e recruta pCRP para a superficie das células necróticas, 
aumentando a remoção das mesmas ou facilitando a ligação e ativação do complemento C1q (MIHLAN et al., 2009). Além disso, tem sido proposto que CFHR4 limita a inflamação, aumentando a atividade do cofator do $C F H$ e a deposição de complemento pela ligação a pCRP, que auxilia na fagocitose de micro-organismos e de células necróticas em tecidos inflamados (HEBECKER et al., 2011). Se CFHR4 regula a ativação do complemento e a opsonização em superficies biológicas por meio de interação com pCRP (CANTSILIERIS et al., 2012), a potencial deleção desse gene levaria a redução na ligação à pCRP e assim limitaria a sua capacidade de inibir a inflamação, conduzindo ao avanço do LES. Uma vez que cada gene CFH-CFHRs representa um componente funcional diferente para a regulação do complemento, sugere-se que o equilíbrio homeostático entre CFH, CFHR3, CFHR1 e CFHR4 é necessário para manter a regulação da ativação do complemento (ZHAO, J. et al., 2011).

As células do sistema imune de pacientes com LES apresentam anormalidades, incluindo a redução na citotoxicidade de células $\mathrm{T}$, ativação irregular de células B e alterações na biossintese de citocinas (ABELSON et al., 2009; NIEWOLD et al., 2007). Nesse contexto, o gene STAT4 (transdutores de sinal e ativador da transcrição) é expresso em células T e B, monócitos, macrófagos, células natural killer (NK), células dendríticas e codifica um fator de transcrição que medeia o efeito de várias citocinas, como $I L-12$, IL-23 e interferon (INF) tipo I (JACOB, C. O. et al., 2009). Por conseguinte, alterações no STAT4 podem afetar a produção de autoanticorpos e a regulação da apoptose (CROW; KIROU, 2004).

GWAS tem demonstrado a contribuição de SNPS no STAT4 G>C (rs7582694) e G>T (rs7574865) em que os alelos C e T foram associados, respectivamente, com maior incidência de LES em vários grupos étnicos e com severidade de comprometimento renal (nefrite), uma das manifestações clínicas mais comuns da doença (HELLQUIST et al., 2010; MARTINEZ et al., 2008). No presente trabalho, identificamos uma deleção de $17,8 \mathrm{~kb}$ no STAT4, detectada pela primeira vez em pacientes com LES, que fornece indícios de que CNVs nesse gene contribuem para a patogênese de LES. Além disso, 
considerando que SNPS no STAT4 foram associados com outras doenças autoimunes, incluindo artrite reumatoide, doença de Crohn, asma e esclerose sistêmica (LI et al., 2011), CNVs no STAT4 podem estar relacionadas com autoimunidade de forma geral.

Além disso, foi encontrada uma deleção no gene IL3RA, receptor da IL3. Esta interleucina e seu respectivo receptor são responsáveis pela ativação da via de sinalização JAK/STAT ( $\underline{K E G G}: \underline{\text { hsa04630) }}$ envolvida com autoimunidade, a qual o STAT4 tem participação (LUO et al., 2012). Deleções no gene IL3RA podem exercer função na geração de fenótipos autoimunes, embora os mecanismos moleculares ainda não tenham sido amplamente estudados.

A maior prevalência de LES em mulheres sugere que genes do cromossomo $X$ poderiam contribuir na etiologia da doença (GUERRA et al., 2012). Pacientes do sexo masculino com síndrome de Klinefelter (47, XXY) apresentam risco semelhante para desenvolver LES em comparação com as mulheres (SAWALHA et al., 2008). A presença de genes de susceptibilidade ao LES no cromossomo X e a superexpressão de genes como resultado da perda da inativação aleatória do $X$ são possíveis explicações que sugerem a existência de efeito de dosagem gênica. A inativação do X é mediada por metilação do DNA (QIN et al., 2012). Entretanto, pacientes com LES apresentam defeitos na metilação do DNA nas células T (SAWALHA; RICHARDSON, 2005), o que torna ambas as cópias dos dois cromossomos X, em pacientes do sexo feminino e do sexo masculino com sindrome de Klinefelter e LES, disponiveis para a transcrição. Este mecanismo é sugerido para explicar a superexpressão de alguns genes do cromossomo X (LU et al., 2007).

Nesse sentido, a distribuição de CNVs nos cromossomos observada na nossa amostra mostrou que a maioria das CNVs detectadas concentra-se no cromossomo X. Dentre elas, grande parte consiste em duplicações nos pacientes do sexo feminino. Dessa forma, podemos inferir que além da deficiência do padrão de metilação, a superexpressão de alguns genes do cromossomo $\mathrm{X}$ pode ser decorrente do aumento do número de cópias dos genes. 
Adicionalmente, os nossos resultados fornecem destaque para a duplicação encontrada no gene MECP2 (Methyl-CpG-binding protein 2), localizado no cromossomo Xq28, em 7 pacientes com LES (seis mulheres e um homem). MECP2 (OMIM\#300005) desempenha papel em dois mecanismos epigenéticos, metilação do DNA e desacetilação de histonas, que resulta no silenciamento da expressão por tornar a configuração da cromatina inacessivel para a transcrição gênica (SAWALHA et al., 2008). Baseado na evidência de que defeitos na metilação do DNA tem sido implicados na patogênese do LES em modelos murinos e humanos (KAISER; CRISWELL, 2010; PATEL; RICHARDSON, 2010), Sawalha et al. (2008) genotiparam 21 SNPs localizados dentro ou entre as regiões flanqueadoras de $M E C P 2$ e constataram forte associação entre o gene e a susceptibilidade a LES em duas populações etnicamente distintas. As interações genéticas e epigenéticas na patogênese da doença podem proporcionar uma ideia mais clara sobre predominância de LES em mulheres e sugerir um novo mecanismo para explicar a superexpressão de genes sensiveis à metilação observados em células $\mathrm{T}$, como o $M E C P 2$, que resulta na produção de células $\mathrm{T}$ autorreativas nos pacientes com LES.

No presente estudo, mostramos pela primeira vez CNVs no pseudogene HLA-DPB2 em pacientes com LES. O MHC no cromossomo 6 contem cerca de 100 genes diferentes que afetam o sistema imune, incluindo aqueles com forte associação com a susceptibilidade ao LES, como os alelos do MHC de classe II $H L A-D R B 1 * 0301$ e $H L A-D R B 1 * 1501$ (FERNANDO et al., 2007). Os alelos HLA$D P B 1$ e $H L A-D P B 2$ apresentam desequilibrio de ligação relativamente baixo com outros haplótipos de MHC (ZHOU, 2009). Embora não tenham sido amplamente estudados como o $H L A-A,-B,-C$, e $-D R$, exercem função semelhante de apresentação de antígeno para ativar células T CD4+ (SABETI et al., 2002) e os polimorfismos nesses genes foram associados com artrite reumatoide (MCHUGH et al., 2006), DM1 (SANCHEZ et al., 2006) e asma (ZHAO, Y. et al., 2009). A deleção de 11,9 kb no HLA-DPB2 encontrada em dois pacientes do conjunto amostral pode contribuir para a patogênese da doença. 
No contexto da autoimunidade de forma geral, Grayson et al. (2010) detectaram cinco CNVs envolvidas com diabetes autoimune do tipo 1 (DM1) na formação de autoanticorpos, dentre elas a deleção no gene SNTG1, que foi a mais frequente nos casos de DM1. O gene SNTG1 está localizado no locus 8q11.12 e codifica gama sintrofina, uma membrana citoplasmática periférica expressa no cérebro (BASHIARDES et al., 2004). Embora o gene não esteja envolvido diretamente com autoimunidade, sugere-se que a deleção de sequências evolutivamente conservadas pode levar a desregulação na dosagem de outros genes que se encontram próximos à região variável do cromossomo 8 (GRAYSON et al., 2010). No presente estudo, encontramos uma deleção de 0,9 kb no gene SNTG1. Genes sensiveis à dosagem, como o SNTG1 podem contribuir na susceptibilidade a doenças autoimunes de forma geral (LLEO et al., 2010).

Em relação às $C N V$ s comuns identificadas no presente estudo, encontramos CNVs recorrentes nos genes KIA1267, ADAM3A e UTG2B15 relacionados com LES ou com autoimunidade (Tabela 14) (LI et al., 2011). Os nossos achados corroboram com os de Bronstad et al. (2011), no qual identificaram CNVs frequentes nos mesmos genes (KIA1267 e ADAM3A) ou família de genes (UTG2B28), em pacientes com doença autoimune de Addison (AD). Após validação destes dados em número maior de pacientes com $\mathrm{AD}$ e controles, a duplicação em $A D A M 3 A$ e a deleção em UTG2B28 foram associadas com a susceptibilidade à AD (BRONSTAD, I. et al., 2011). O mecanismo pelo qual esta susceptibilidade é conferida é pouco claro, mas pode envolver inativação de esteroide (UGT2B28) e maturação de células T $(A D A M 3 A)$. Esses achados sugerem que CNVs comuns em genes imunoregulatórios podem ser fatores de risco para o desenvolvimento de doenças autoimunes. 


\section{CONCLUSÕES \\ E PERSPECTIVAS}

Este foi o primeiro estudo que desenvolveu triagem de CNVs em larga escala em pacientes com LES.

A metodologia aplicada no presente trabalho mostrou-se eficiente na geração de dados confiáveis e de alta densidade.

A proporção variável do genoma representada pelas CNVs em nosso trabalho foi menor do que a relatada inicialmente na literatura, mas concordou com outros trabalhos recentemente desenvolvidos e metodologicamente semelhantes.

A distribuição de CNVs nos cromossomos revelou maior prevalência de CNVs no cromossomo $\mathrm{X}$, o que está de acordo com dados de outros trabalhos que apontam relação entre genes do $\mathrm{X}$ e autoimunidade e com os traços epidemiológicos da doença.

O perfil de CNVs apresentou prevalência de CNVs recorrentes, categorizadas em CNVRs distribuídas ao longo do genoma.

Embora o tamanho de uma $C N V$ por si só não possa ser usado como preditor de patogenicidade, as diferenças encontradas no tamanho das CNVs nos pacientes com LES em relação à literatura e ao principal banco de dados de variantes estruturais, o $D G V$, sugere que grandes $C N V s$ podem estar envolvidas na etiologia do LES

A análise comparativa das CNVs encontradas na amostra de LES com banco de dados de variantes estruturais ( $D G V, D E C I P H E R$ e ISCA) possibilitou a descrição de nove CNVs não catalogadas anteriormente nestas bases de dados.

Identificamos CNVs em cinco genes previamente relacionados com LES, ainda não descritas na literatura em associação com a doença, que podem contribuir para a susceptibilidade a LES e/ou a doenças autoimunes. 
As nossas perspectivas consistem em dar seguimento ao estudo iniciado, analisando os controles, já coletados, em comparação com o grupo de pacientes com seu número aumentado para um tamanho adequado a estudos de associação e que permitam conclusões que certamente transcenderão a aplicação restrita ao LES, pois terão reflexos mais amplos sobre a compreensão das bases genéticas dos fenótipos autoimunes. 


\section{REFERÊNCIAS BIBLIOGRÁFICAS}

ABBAS, A. K.; LICHTMAN, A. H.; PILLAI, S. Cellular and Molecular Immunology: with STUDENT CONSULT Online Access. Saunders, 2010.

ABELSON, A. K. et al. STAT4 associates with systemic lupus erythematosus through two independent effects that correlate with gene expression and act additively with IRF5 to increase risk. Annals of the rheumatic diseases, v. 68, n. 11, p. 1746-1753, 2009.

AHMAD, Y. A.; BRUCE, I. N. Genetic epidemiology: systemic lupus erythematosus. Arthritis Res, v. 3, n. 6, p. 331-6, 2001.

AITMAN, T. J. et al. Copy number polymorphism in Fcgr3 predisposes to glomerulonephritis in rats and humans. Nature, v. 439, n. 7078, p. 851855, 2006.

ALARCON-SEGOVIA, D. et al. Familial aggregation of systemic lupus erythematosus, rheumatoid arthritis, and other autoimmune diseases in 1,177 lupus patients from the GLADEL cohort. Arthritis \& Rheumatism, v. 52, n. 4, p. 1138-1147, 2005.

ALKAN, C.; COE, B. P.; EICHLER, E. E. Genome structural variation discovery and genotyping. Nat Rev Genet, v. 12, n. 5, p. 363-76, 2011.

AMUR, S.; PAREKH, A.; MUMMANENI, P. Sex differences and genomics in autoimmune diseases. Journal of autoimmunity, 2012.

ARDOIN, S. P.; PISETSKY, D. S. Developments in the scientific understanding of lupus. Arthritis Res Ther, v. 10, n. 5, p. 218, 2008.

BASHIARDES, S. et al. SNTG1, the gene encoding y-syntrophin: a candidate gene for idiopathic scoliosis. Human genetics, v. 115, n. 1, p. 81-89, 2004.

BLAUW, H. M. et al. Copy-number variation in sporadic amyotrophic lateral sclerosis: a genome-wide screen. Lancet Neurol, v. 7, n. 4, p. 319-26, 2008.

BOCHUKOVA, E. G. et al. Large, rare chromosomal deletions associated with severe early-onset obesity. Nature, v. 463, n. 7281, p. 666-70, 2010.

BORBA, E. F. et al. Consenso de lúpus eritematoso sistêmico. Rev Bras Reumatol, v. 48, n. 4, p. 196-207, 2008.

BOUTS, Y. M. et al. Apoptosis and NET formation in the pathogenesis of SLE. Autoimmunity, n. 0, p. 1-1, 2012. 
BRONSTAD, I. et al. Genome-wide copy number variation (CNV) in patients with autoimmune Addison's disease. BMC medical genetics, v. 12, n. 1, p. $111,2011$.

CANTSILIERIS, S. et al. Comprehensive Analysis of Copy Number Variation of Genes at Chromosome 1 and 10 Loci Associated with Late Age Related Macular Degeneration. PloS one, v. 7, n. 4, p. e35255, 2012.

CASCIOLA-ROSEN, L. A.; ANHALT, G.; ROSEN, A. Autoantigens targeted in systemic lupus erythematous are clustered in two populations of surface structures on apoptotic keratinocytes. J Exp Med, v. 179, p. 1317-1330, 1994.

CERVINO, A. C.; TSINOREMAS, N. F.; HOFFMAN, R. W. A Genome Wide Study of Lupus. Annals of the New York Academy of Sciences, v. 1110, n. 1, p. 131-139, 2007.

CHOY, K. W. et al. The impact of human copy number variation on a new era of genetic testing. BJOG, v. 117, n. 4, p. 391-8, 2010.

CLEMENS, L. E.; SIITERI, P. K.; STITES, D. P. Mechanism of immunosuppression of progesterone on maternal lymphocyte activation during pregnancy. The Journal of Immunology, v. 122, n. 5, p. 1978-1985, 1979.

COFFMAN, R. L.; LEBMAN, D. A.; ROTHMAN, P. Mechanism and regulation of immunoglobulin isotype switching. Advances in immunology, v. 54, p. 229-270, 1993.

COSTENBADER, K. H. et al. Reproductive and menopausal factors and risk of systemic lupus erythematosus in women. Arthritis \& Rheumatism, v. 56, n. 4, p. 1251-1262, 2007.

CROW, M. K.; KIROU, K. A. Interferon-[alpha] in systemic lupus erythematosus. Current opinion in rheumatology, v. 16, n. 5, p. 541-547, 2004.

DISKIN, S. J. et al. Copy number variation at 1q21. 1 associated with neuroblastoma. Nature, v. 459, n. 7249, p. 987-991, 2009.

DORNER, T.; GIESECKE, C.; LIPSKY, P. E. Mechanisms of B cell autoimmunity in SLE. Arthritis research \& therapy, v. 13, n. 5, p. 243, 2010.

EDBERG, J. C. et al. Genetic linkage and association of Fcy receptor IIIA (CD16A) on chromosome 1q23 with human systemic lupus erythematosus. Arthritis \& Rheumatism, v. 46, n. 8, p. 2132-2140, 2002. 
FANCIULLI, M. et al. FCGR3B copy number variation is associated with susceptibility to systemic, but not organ-specific, autoimmunity. Nature genetics, v. 39, n. 6, p. 721-723, 2007.

FERNANDO, M. M. et al. Identification of two independent risk factors for lupus within the MHC in United Kingdom families. PLoS genetics, v. 3, n. 11, p. e192, 2007.

GIBBS, R. A. et al. The international HapMap project. Nature, v. 426, n. 6968, p. 789-796, 2003.

GLEICHER, N.; BARAD, D. H. Gender as risk factor for autoimmune diseases. Journal of autoimmunity, v. 28, n. 1, p. 1-6, 2007.

GONZALEZ, E. et al. The influence of CCL3L1 gene-containing segmental duplications on HIV-1/AIDS susceptibility. Science Signalling, v. 307, n. 5714, p. 1434, 2005.

GRAYSON, B. L. et al. Genome-wide analysis of copy number variation in type 1 diabetes. PloS one, v. 5, n. 11, p. e15393, 2010..

GUERRA, S. G.; VYSE, T. J.; GRAHAM, D. S. C. The genetics of lupus: a functional perspective. enzyme, v. 2, p. 3, 2012.

HARLEY, I. T. W. et al. Genetic susceptibility to SLE: new insights from fine mapping and genome-wide association studies. Nature Reviews Genetics, v. 10, n. 5, p. 285-290, 2009.

HE, Y.; HOSKINS, J. M.; MCLEOD, H. L. Copy number variants in pharmacogenetic genes. Trends in Molecular Medicine, 2011.

HEBECKER, M. et al. Molecular basis of C-reactive protein binding and modulation of complement activation by factor H-related protein 4. Molecular immunology, v. 47, n. 6, p. 1347-1355, 2011.

HELLQUIST, A. et al. Variation in STAT4 is associated with systemic lupus erythematosus in a Finnish family cohort. Annals of the rheumatic diseases, v. 69, n. 5, p. 883-886, 2010.

HOCHBERG, M. C. The application of genetic epidemiology to systemic lupus erythematosus. J Rheumatol, v. 14, n. 5, p. 867-9, 1987.

HOCHBERG, M. C. Updating the American College of Rheumatology revised criteria for the classification of systemic lupus erythematosus. Arthritis \& Rheumatism, v. 40, n. 9, p. 1725-1725, 1997.

HOLLOX, E. J. et al. Psoriasis is associated with increased $\beta$-defensin genomic copy number. Nature genetics, v. 40, n. 1, p. 23-25, 2007. 
IAFRATE, A. J. et al. Detection of large-scale variation in the human genome. Nature genetics, v. 36, n. 9, p. 949-951, 2004.

IKEDA, M. et al. Copy number variation in schizophrenia in the Japanese population. Biological Psychiatry; Biological Psychiatry, 2010.

INGELMAN-SUNDBERG, $M$. et al. Influence of cytochrome P450 polymorphisms on drug therapies: pharmacogenetic, pharmacoepigenetic and clinical aspects. Pharmacology \& therapeutics, v. 116, n. 3, p. 496$526,2007$.

ISKOW, R. C.; GOKCUMEN, O.; LEE, C. Exploring the role of copy number variants in human adaptation. Trends in Genetics, 2012.

ITSARA, A. et al. Population analysis of large copy number variants and hotspots of human genetic disease. The American Journal of Human Genetics, v. 84, n. 2, p. 148-161, 2009.

JACOB, C. O. et al. Identification of IRAK1 as a risk gene with critical role in the pathogenesis of systemic lupus erythematosus. Proceedings of the National Academy of Sciences, v. 106, n. 15, p. 6256-6261, 2009.

JACOB, K. et al. Duplication of $7 q 34$ is specific to juvenile pilocytic astrocytomas and a hallmark of cerebellar and optic pathway tumours. British journal of cancer, v. 101, n. 4, p. 722-733, 2009.

JAKOBSSON, M. et al. Genotype, haplotype and copy-number variation in worldwide human populations. Nature, v. 451, n. 7181, p. 998-1003, 2008.

KAISER, R.; CRISWELL, L. A. Genetics research in systemic lupus erythematosus for clinicians: methodology, progress, and controversies. Current opinion in rheumatology, v. 22, n. 2, p. 119, 2010.

KONDRASHOV, A. S. Direct estimates of human per nucleotide mutation rates at 20 loci causing Mendelian diseases. Human mutation, v. 21, n. 1, p. $12-27,2002$.

LAU, C.; YIN, G.; MOK, M. Ethnic and geographical differences in systemic lupus erythematosus: an overview. Lupus, v. 15, n. 11, p. 715-719, 2006.

LEHMANN, P. et al. Experimental reproduction of skin lesions in lupus erythematosus by UVA and UVB radiation. Journal of the American Academy of Dermatology, v. 22, n. 2, p. 181-187, 1990.

LETTRE, G.; RIOUX, J. D. Autoimmune diseases: insights from genome-wide association studies. Human molecular genetics, v. 17, n. R2, p. R116R121, 2008. 
LI, P. et al. Association of genetic variations in the STAT4 and IRF7/KIAA1542 regions with systemic lupus erythematosus in a Northern Han Chinese population. Human immunology, v. 72, n. 3, p. 249, 2011.

LLEO, A. et al. Definition of human autoimmunity autoantibodies versus autoimmune disease. Autoimmunity reviews, v. 9, n. 5, p. A259-A266, 2010.

LU, Q. et al. Demethylation of CD40LG on the inactive $\mathrm{X}$ in $\mathrm{T}$ cells from women with lupus. The Journal of Immunology, v. 179, n. 9, p. 63526358, 2007.

LUO, X. et al. The Interleukin 3 Gene (IL3) Contributes to Human Brain Volume Variation by Regulating Proliferation and Survival of Neural Progenitors. PloS one, v. 7, n. 11, p. e50375, 2012.

LUPSKI, J. R. Genomic rearrangements and sporadic disease. Nature genetics, v. 39, p. S43-S47, 2007.

MAIDHOF, W.; HILAS, O. Lupus: An Overview of the Disease And Management Options. Pharmacy and Therapeutics, v. 37, n. 4, p. 240, 2012.

MANOLIO, T. A. et al. Finding the missing heritability of complex diseases. Nature, v. 461, n. 7265, p. 747-753, 2009.

MARTINEZ, A. et al. Association of the STAT4 gene with increased susceptibility for some immune mediated diseases. Arthritis \& Rheumatism, v. 58, n. 9, p. 2598-2602, 2008.

MCCARROLL, S. A. Extending genome-wide association studies to copynumber variation. Human molecular genetics, v. 17, n. R2, p. R135-R142, 2008.

MCCARTHY, M. I. et al. Genome-wide association studies for complex traits: consensus, uncertainty and challenges. Nature Reviews Genetics, v. 9, n. 5, p. 356-369, 2008.

MCHUGH, N. J. et al. MHC class II, tumour necrosis factor $\hat{\mathrm{I}} \pm$, and lymphotoxin $\hat{\mathrm{I}} \pm$ gene haplotype associations with serological subsets of systemic lupus erythematosus. Annals of the rheumatic diseases, v. $65, \mathrm{n}$. 4, p. 488-494, 2006.

MCKINNEY, C. et al. Association of variation in $\mathrm{Fc}^{3}$ receptor 3B gene copy number with rheumatoid arthritis in Caucasian samples. Annals of the rheumatic diseases, v. 69, n. 9, p. 1711-1716, 2010. 
MI, H. et al. PANTHER version 7: improved phylogenetic trees, orthologs and collaboration with the Gene Ontology Consortium. Nucleic acids research, v. 38, n. suppl 1, p. D204-D210, 2010.

MIHLAN, M. et al. Human complement factor $\mathrm{H}$-related protein 4 binds and recruits native pentameric C-reactive protein to necrotic cells. Molecular immunology, v. 46, n. 3, p. 335-344, 2009.

MILLER, S.; DYKES, D.; POLESKY, H. A simple salting out procedure for extracting DNA from human nucleated cells. Nucleic acids research, v. 16, n. 3, p. 1215, 1988.

MORRIS, D. L. et al. Evidence for both copy number and allelic (NA1/NA2) risk at the FCGR3B locus in systemic lupus erythematosus. European Journal of Human Genetics, v. 18, n. 9, p. 1027-1031, 2010.

MOSER, K. L. et al. Genome scan of human systemic lupus erythematosus: evidence for linkage on chromosome $1 \mathrm{q}$ in African-American pedigrees. Proceedings of the National Academy of Sciences, v. 95, n. 25, p. 1486914874, 1998.

MUELLER, M. et al. Genomic Pathology of SLE-Associated Copy-Number Variation at the FCGR2C/FCGR3B/FCGR2B Locus. The American Journal of Human Genetics, 2013.

MUNOZ, L. et al. SLE a disease of clearance deficiency? Rheumatology, v. 44, n. 9, p. 1101-1107, 2005.

MUSONE, S. L. et al. Multiple polymorphisms in the TNFAIP3 region are independently associated with systemic lupus erythematosus. Nature genetics, v. 40, n. 9, p. 1062-1064, 2008.

NACHMAN, M. W.; CROWELL, S. L. Estimate of the mutation rate per nucleotide in humans. Genetics, v. 156, n. 1, p. 297-304, 2000.

NIEWOLD, T. et al. High serum IFN-ÎI activity is a heritable risk factor for systemic lupus erythematosus. Genes and immunity, v. 8, n. 6, p. 492-502, 2007.

PATEL, D. R.; RICHARDSON, B. C. Epigenetic mechanisms in lupus. Current opinion in rheumatology, v. 22, n. 5, p. 478-482, 2010.

PERRY, G. H. et al. Diet and the evolution of human amylase gene copy number variation. Nature genetics, v. 39, n. 10, p. 1256-1260, 2007.

PONS-ESTEL, G. J. et al. Understanding the epidemiology and progression of systemic lupus erythematosus. Seminars in arthritis and rheumatism, 2010. NIH Public Access. p.257. 
PROKUNINA, L. et al. A regulatory polymorphism in PDCD1 is associated with susceptibility to systemic lupus erythematosus in humans. Nature genetics, v. 32, n. 4, p. 666-669, 2002.

PTACEK, T. et al. Copy number variants in genetic susceptibility and severity of systemic lupus erythematosus. Cytogenetic and genome research, v. 123, n. 1-4, p. 142-147, 2008.

QIN, H. H. et al. Associations between aberrant DNA methylation and transcript levels of DNMT1 and MBD2 in CD4+ T cells from patients with systemic lupus erythematosus. Australasian Journal of Dermatology, 2012.

RAVIRAJAN, C. T. et al. Genetic, structural and functional properties of an IgG DNA binding monoclonal antibody from a lupus patient with nephritis. European journal of immunology, v. 28, n. 1, p. 339-350, 1998.

REDON, R. et al. Global variation in copy number in the human genome. Nature, v. 444, n. 7118, p. 444-454, 2006.

SABETI, P. C. et al. Detecting recent positive selection in the human genome from haplotype structure. Nature, v. 419, n. 6909, p. 832-837, 2002.

SANCHEZ, E. et al. Phenotypic associations of genetic susceptibility loci in systemic lupus erythematosus. Annals of the rheumatic diseases, v. 70, n. 10, p. 1752-1757, 2011.

SANCHEZ, E. et al. No primary association of MICA polymorphism with systemic lupus erythematosus. Rheumatology, v. 45, n. 9, p. 1096-1100, 2006.

SARZI-PUTTINI, P. et al. Environment and systemic lupus erythematosus: an overview. Autoimmunity, v. 38, n. 7, p. 465-472, 2005.

SATO, E. I. Lúpus eritematoso sistêmico. Prado F C. Atualização Terapêutica, p. 1382-7, 2001.

SATO, E. I. et al. Lúpus Eritematoso Sistêmico. Revista brasileira de reumatologia $=$ Brazilian journal of rheumatology. Campinas. Vol. 48, $n$. 4 (jul./ago. 2008), p. 196-207, 2008..

SAWALHA, A. H.; RICHARDSON, B. DNA methylation in the pathogenesis of systemic lupus erythematosus. Current Pharmacogenomics, v. 3, n. 1, p. 73-78, 2005..

SAWALHA, A. H. et al. Common variants within MECP2 confer risk of systemic lupus erythematosus. PloS one, v. 3, n. 3, p. e1727, 2008. 
SCOFIELD, R. H. et al. Klinefelter's syndrome $(47, \mathrm{XXY})$ in male systemic lupus erythematosus patients: Support for the notion of a gene dose effect from the $X$ chromosome. Arthritis \& Rheumatism, v. 58, n. 8, p. 25112517, 2008.

SEBAT, J. Major changes in our DNA lead to major changes in our thinking. Nat Genet, v. 39, n. 7 Suppl, p. S3-5, 2007.

SEBAT, J. et al. Large-scale copy number polymorphism in the human genome. Science, v. 305, n. 5683, p. 525-8, 2004.

SHAIKH, T. H. et al. High-resolution mapping and analysis of copy number variations in the human genome: a data resource for clinical and research applications. Genome research, v. 19, n. 9, p. 1682-1690, 2009.

SHARP, A. J. et al. Segmental duplications and copy-number variation in the human genome. American journal of human genetics, v. $77, \mathrm{n} .1$, p. $78,2005$.

STANKIEWICZ, P.; LUPSKI, J. R. Structural variation in the human genome and its role in disease. Annual review of medicine, v. 61, p. 437-455, 2010.

STRANGER, B. E. et al. Relative impact of nucleotide and copy number variation on gene expression phenotypes. Science, v. 315, n. 5813, p. 848853, 2007.

TAN, E. M. et al. The 1982 revised criteria for the classification of systemic lupus erythematosus. Arthritis \& Rheumatism, v. 25, n. 11, p. 1271-1277, 1982.

TUZUN, E. et al. Fine-scale structural variation of the human genome. Nature genetics, v. 37, n. 7, p. 727-732, 2005.

VAN OMMEN, G. J. B. Frequency of new copy number variation in humans. Nature genetics, v. 37, n. 4, p. 333-334, 2005.

VOGLER, C. et al. Microarray-based maps of copy-number variant regions in European and sub-Saharan populations. PloS one, v. 5, n. 12, p. e15246, 2010.

VRIJENHOEK, T. et al. Recurrent CNVs disrupt three candidate genes in schizophrenia patients. The American Journal of Human Genetics, v. 83, n. 4, p. 504-510, 2008.

WAIN, L. V.; TOBIN, M. D., Eds. Copy number variation. Methods Mol Biol, v.713, p.167-83, Methods Mol Biol, 2010/12/15 ed. 2011. 
WALTERS, R. et al. A new highly penetrant form of obesity due to deletions on chromosome 16p11. 2. Nature, v. 463, n. 7281, p. 671-675, 2010.

WILLCOCKS, L. C.; SMITH, K.; CLATWORTHY, M. R. Low-affinity Fcg receptors, autoimmunity and infection. Expert Rev. Mol. Med, v. 11, p. e24, 2009.

WU, Y. et al. Phenotypes, genotypes and disease susceptibility associated with gene copy number variations: complement $\mathrm{C} 4 \mathrm{CNVs}$ in European American healthy subjects and those with systemic lupus erythematosus. Cytogenetic and genome research, v. 123, n. 1-4, p. 131-141, 2008.

YANG, M. L. et al. Lupus autoimmunity altered by cellular methylation metabolism. Autoimmunity, 2012.

YANG, Y. et al. Gene copy-number variation and associated polymorphisms of complement component $\mathrm{C} 4$ in human systemic lupus erythematosus (SLE): low copy number is a risk factor for and high copy number is a protective factor against SLE susceptibility in European Americans. The American Journal of Human Genetics, v. 80, n. 6, p. 1037-1054, 2007.

YU, B. et al. Copy number variations of interleukina $17 \mathrm{~F}$, interleukina 21, and interleukina 22 are associated with systemic lupus erythematosus. Arthritis \& Rheumatism, v. 63, n. 11, p. 3487-3492, 2011.

ZHANG, F. et al. Copy number variation in human health, disease, and evolution. Annual review of genomics and human genetics, v. 10, p. 451$481,2009$.

$\mathrm{ZHAO}$, J. et al. Association of genetic variants in complement factor $\mathrm{H}$ and factor H-related genes with systemic lupus erythematosus susceptibility. PLoS genetics, v. 7, n. 5, p. e1002079, 2011.

ZHAO, Y. et al. Th17 immunity in patients with allergic asthma. International archives of allergy and immunology, v. 151, n. 4, p. 297307, 2009.

ZHOU, F. Molecular mechanisms of IFN-a to up-regulate MHC class i antigen processing and presentation. International reviews of immunology, v. 28, n. 3-4, p. 239-260, 2009. 
Apêndice 
Apêndice 1. Características clínicas dos pacientes selecionados.

\begin{tabular}{|c|c|c|c|c|c|c|}
\hline \multirow{2}{*}{ Paciente } & \multirow{2}{*}{ Sexo } & \multirow{2}{*}{$\begin{array}{l}\text { Ano do } \\
\text { Nascimento }\end{array}$} & \multicolumn{4}{|c|}{ Manifestações Clínicas } \\
\hline & & & Infecções & Doenças & Neurológicas & Cutâneas \\
\hline 1 & Masculino & 1976 & $\begin{array}{l}\text { Serosite, herpes zoster, } \\
\text { úlcera oral }\end{array}$ & $\begin{array}{l}\text { Nefrite, Cushing iatrogênico, alterações } \\
\text { hematológicas, obesidade, poliartrite, } \\
\text { GNMP }\end{array}$ & & Tinea corporis \\
\hline 2 & Masculino & 1985 & $\begin{array}{l}\text { Staphilococcemia, ITU, } \\
\text { stafilococcus aureus, } \\
\text { pneumonia hospitalar }\end{array}$ & $\begin{array}{l}\text { Nefrite, artrite, HAS, leucopenia, } \\
\text { insuficiência renal, obesidade, necrose } \\
\text { tubular aguda, fibromialgia, } \\
\text { fotossensibilidade, GNPD }\end{array}$ & & $\begin{array}{l}\text { Rash malar, lesões } \\
\text { pele, criptocose } \\
\text { cutânea, ptiríase } \\
\text { versicolor, Tinea } \\
\text { cruris }\end{array}$ \\
\hline 3 & Masculino & 1985 & Serosite, pleurite & $\begin{array}{l}\text { Nefrite, artrite, vasculite, pancitopenia, } \\
\text { reação alérgica a contraste }\end{array}$ & & $\begin{array}{l}\text { Rash malar, } \\
\text { púrpura, lesões } \\
\text { cutâneas }\end{array}$ \\
\hline 4 & Masculino & 1972 & & $\begin{array}{l}\text { HAS, linfopenia, rinite pigmentar, } \\
\text { glomerulonefrite, Sd. Nefrótica }\end{array}$ & & Rash malar \\
\hline 5 & Masculino & 1984 & Serosite, miocardite & $\begin{array}{l}\text { Nefrite, artrite, derrame pleural, derrame } \\
\text { pericárdio, rinite, valvulite mitral, SAF }\end{array}$ & & $\begin{array}{l}\text { Rash malar, } \\
\text { ptiríase }\end{array}$ \\
\hline 6 & Feminino & 1964 & $\begin{array}{l}\text { Sinusite, herpes zoster, } \\
\text { pneumonia }\end{array}$ & $\begin{array}{l}\text { Nefrite, artrite, gânglio axilar, leucocitúria, } \\
\text { fibromialgia, leucopenia, otossesibilidade, } \\
\text { diabetes melitus, GNMF focal, SAF, } \\
\text { mucosite, artralgia, }\end{array}$ & Psicose & Rash malar \\
\hline 7 & Feminino & 1978 & $\begin{array}{l}\text { úlceras orais, virose trato } \\
\text { respiratório alto }\end{array}$ & $\begin{array}{l}\text { Nefrite, artrite, HAS, fotossensibilidade, } \\
\text { fibromialgia, GNPD }\end{array}$ & $\begin{array}{l}\text { Psicose lúpica, } \\
\text { convulsão }\end{array}$ & $\begin{array}{l}\text { Rash malar , LES } \\
\text { cutâneo }\end{array}$ \\
\hline 8 & Feminino & 1966 & $\begin{array}{l}\text { Serosite, serosite pericárdio, } \\
\text { herpes zoster, pleurite, } \\
\text { pielonefrite, monolíase oral, } \\
\text { diarréia aguda, estomatite, } \\
\text { celulite, pústula hálux }\end{array}$ & $\begin{array}{l}\text { Nefrite, derrame pleural, ascite, doença } \\
\text { péptica, gastrite, esofagite, DPC, } \\
\text { abcesso dentário, obesidade, FOP, } \\
\text { osteoporose, SAF }\end{array}$ & $\begin{array}{l}\text { Depressão, psicose, } \\
\text { vasculite SNC }\end{array}$ & Verrugas palmares \\
\hline 9 & Feminino & 1962 & $\begin{array}{l}\text { ITU, pneumonia, pielonefrite, } \\
\text { pneumonia bacteriana, } \\
\text { diarréia }\end{array}$ & $\begin{array}{l}\text { Nefrite, HAS, serosite, SAF, obesidade, } \\
\text { TVP, TEP, GNPD, obesidade mórbida, } \\
\text { Cushing iatrogênico, serosite cutâneo- } \\
\text { articular, vulvovaginite, leucopenia, } \\
\text { derrame pleural e pericárdio, DMII, LES } \\
\text { hematológico, distúrbio coagulação, } \\
\text { resistência insulínica }\end{array}$ & Ansiedade & $\begin{array}{l}\text { Rash malar, Sd. } \\
\text { Pós-trobótica em } \\
\text { MIE, tromboflebite }\end{array}$ \\
\hline
\end{tabular}




\begin{tabular}{|c|c|c|c|c|c|c|}
\hline 10 & Feminino & 1951 & $\begin{array}{l}\text { Diarréia aguda infecciosa } \\
\text { superior, sífilis tratada }\end{array}$ & $\begin{array}{l}\text { Nefrite, artrite joelho, HAS, obesidade, } \\
\text { pico hipertensivo, bócio difuso, doença } \\
\text { de Graves, poliartrite, GNM }\end{array}$ & Sd. Climatério & $\begin{array}{l}\text { Ptiríase versicolor, } \\
\text { Tinea corporis }\end{array}$ \\
\hline 11 & Feminino & 1982 & $\begin{array}{l}\text { Serosite, ITU, sinusite, HPV, } \\
\text { vulvovaginite }\end{array}$ & $\begin{array}{l}\text { Nefrite, artrite, edema generalizado, } \\
\text { fotossensibilidade, linfopenia, } \\
\text { plaquetopenia, adenomegalia cervical, } \\
\text { GNPD }\end{array}$ & Neuropsiquiátrico & $\begin{array}{l}\text { Rash malar } \\
\text { Pediculose, } \\
\text { ptiríase versicolor, } \\
\text { Tinea corporis, } \\
\text { lúpus cutâneo }\end{array}$ \\
\hline 12 & Feminino & 1941 & $\begin{array}{l}\text { ITU, herpes zoster, } \\
\text { furunculose, virose } \\
\text { respiratória }\end{array}$ & $\begin{array}{l}\text { Nefrite, artrite, artralgia, osteoartrite, } \\
\text { HAS, gastrite medicamentosa, alopenia, } \\
\text { constipação intestinal, lombociatalgia, } \\
\text { leucorréia, arritmia supraventricular, } \\
\text { neoplasia, hepatomegalia, obesidade, } \\
\text { tosse alérgica, dispepsia, fibromialgia, } \\
\text { dislipidemia, esofagite erosiva, IVAS }\end{array}$ & $\begin{array}{l}\text { Distúrbio emocional, } \\
\text { Sd, climatério }\end{array}$ & $\begin{array}{l}\text { ManChAS no } \\
\text { corpo, ptiríase } \\
\text { versicolor, } \\
\text { dermatite } \\
\text { seborréica }\end{array}$ \\
\hline 13 & Feminino & 1961 & $\begin{array}{l}\text { Serosite, ITU, pneumonite, } \\
\text { pericardite, pleuriteotite, } \\
\text { vaginose }\end{array}$ & $\begin{array}{l}\text { Nefrite IIB, osteoartrite, aborto, } \\
\text { fibromialgia, derrame pleural, aborto de } \\
\text { repetição, miomatose uterina, linfopenia, } \\
\text { sobrepeso, granuloma em FSV, } \\
\text { hiperatividade do detrusor }\end{array}$ & $\begin{array}{l}\text { Transtorno do pânico, } \\
\text { Sd. Climatério, } \\
\text { cefaléia crônica diária, } \\
\text { abuso analgésico, } \\
\text { psicose }\end{array}$ & LED \\
\hline 14 & Feminino & 1950 & Serosite, ITU & $\begin{array}{l}\text { Nefrite, artrite, HAS, derrame pericárdio, } \\
\text { fibromialgia, anemia ferrotipica, } \\
\text { maculopatia por cloroquina, } \\
\text { deslocamento retina, glaucoma agudo, } \\
\text { coroidite secundária ao LES, doença } \\
\text { diverticular colônica, fotossensibilidade, } \\
\text { GNM }\end{array}$ & $\begin{array}{l}\text { Neurocisticercose, } \\
\text { transtorno depressivo }\end{array}$ & LES cutâneo \\
\hline 15 & Feminino & 1935 & ITU, celulite, erisipela & $\begin{array}{l}\text { Nefrite, HAS, pneumopatia, úlcera MIE, } \\
\text { insuficiência vascular, úlcera flebopática, } \\
\text { fotossensibilidade, ateromatose carótida, } \\
\text { osteoporose, anemia, SAAF }\end{array}$ & Psicose & $\begin{array}{l}\text { LES } \\
\text { cutâneo/articular, } \\
\text { LED, onicomicose }\end{array}$ \\
\hline 16 & Feminino & 1986 & $\begin{array}{l}\text { ITU, miosite, polimiosite, } \\
\text { pneumoniasinusite maxilar, } \\
\text { pneumonite }\end{array}$ & $\begin{array}{l}\text { Nefrite, artrite crônica juvenil, poliartrite } \\
\text { simétrica, monoartrite tornozelo } \\
\text { hematúria, ascite, fibrose pulmonar, } \\
\text { cistite hemorrágica, fibrose cardíaca, } \\
\text { anemia hemolítica, fibromialgia, } \\
\text { taquicardia }\end{array}$ & Crises convulsivas & Seborréia \\
\hline
\end{tabular}




\begin{tabular}{|c|c|c|c|c|c|c|}
\hline 17 & Feminino & 1963 & $\begin{array}{l}\text { HPV, sinusite, pielonefrite, } \\
\text { celulite periorbitária }\end{array}$ & $\begin{array}{l}\text { Nefrite, poliartralgia, poliartrite, HAS, } \\
\text { leucopenia, vasculite, dor abdominal, } \\
\text { monilíase vaginal, tendinite, DMTC, } \\
\text { distimia, rinite, asma, fibromialgia, } \\
\text { DRGE, fotossensibilidade, toxoplasmose, }\end{array}$ & Síndrome do pânico & Rash malar \\
\hline 18 & Feminino & 1974 & $\begin{array}{l}\text { Serosite (pleurite, pericardite), } \\
\text { ITU, sinusite }\end{array}$ & $\begin{array}{l}\text { Nefrite, artrite, lesão ocular por } \\
\text { cloroquina, derrame pericárdio }\end{array}$ & Psicose & $\begin{array}{l}\text { Dermatite de } \\
\text { interface }\end{array}$ \\
\hline 19 & Feminino & 1977 & Serosite, ITU & $\begin{array}{l}\text { Nefrite, artrite, poliartrite, HAS, litíase } \\
\text { renal, taquicardia episódica, } \\
\text { vulvovaginite, cisto ovariano, anemia, } \\
\text { fibromialgia, }\end{array}$ & LES neuropsiquiátrico & Rash malar \\
\hline 20 & Feminino & 1956 & ITU & $\begin{array}{l}\text { Nefrite, hematúria secundária nefrite, } \\
\text { anemia secundária hematúria, } \\
\text { fotossensibilidade, anemia hemolítica, } \\
\text { fibromialgia, linfopenia, colecistite aguda, } \\
\text { gastrite aguda }\end{array}$ & Labirintopatia & LES discóide \\
\hline 21 & Feminino & 1948 & Serosite, sinusite, diarréia & $\begin{array}{l}\text { Nefrite, artrite, poliartrite, HAS, Cushing } \\
\text { medicamentoso, TBG, fibromialgia, } \\
\text { tabagismo, alterações pulmonares } \\
\text { residuais, necrose asséptica do } \\
\text { úmero,osteopenia, fibromialgia }\end{array}$ & Depressão & Celulite em MIE \\
\hline 22 & Feminino & 1955 & ITU & $\begin{array}{l}\text { Nefrite, HAS, obesidade, fibromialgia, } \\
\text { gastrite medicamentosa, tricomoníase, } \\
\text { mioma, DMII, fotossensibilidade, etilismo, } \\
\text { pé diabético infectado }\end{array}$ & $\begin{array}{l}\text { Neuropatia secundária } \\
\text { a talidamida, cefaleia }\end{array}$ & $\begin{array}{l}\text { Rash malar, } \\
\text { vasculite cutânea }\end{array}$ \\
\hline 23 & Feminino & 1963 & $\begin{array}{l}\text { Serosite (pleural, pericárdio), } \\
\text { ITU, sífilis, celulite }\end{array}$ & $\begin{array}{l}\text { Nefrite, artrite, hipertrofia mamária, } \\
\text { DMTC, Sd. Raynaud, Cushing } \\
\text { iatrogênico, pancreatite, } \\
\text { fotossensibilidade, alterações } \\
\text { hematológicas, varizes, hipertiroidismo, } \\
\text { osteopenia, menopausa precoce, doença } \\
\text { de Graves, lesão vulvar hiperplásica, } \\
\text { derrame pericárdio, dislipidemia, } \\
\text { sobrepeso }\end{array}$ & Transtorno ansiedade & Mioma submucoso \\
\hline
\end{tabular}




\begin{tabular}{llll}
\hline 24 & Masculino 1979 & $\begin{array}{l}\text { Serosite, herpes zoster, } \\
\text { pneumonia, pericardite, } \\
\text { pneumonite, hepatite B } \\
\text { crônica, monolíase oral }\end{array}$ & $\begin{array}{l}\text { Nefrite, artralgia, febre, adenomegalia, } \\
\text { colagenase, derrame, pericárdio, } \\
\text { leucopenia, febre, GNPD, SAF, AHAI }\end{array}$ \\
\hline
\end{tabular}

Abreviaturas: AHAI - Anemia hemolítica autoimune; DMII - Diabetes mellitus tipo 2; DMTC - Doença mista do tecido conjuntivo; DRGE - Doença do refluxo gastroesofágico; FOP - Falência ovariana prematura; FSV - Fundo de saco vaginal; GN membranosa = GNM = Glomerulonefrite membranosa; GNMP Glomerulonefrite membranoproliferativa; GNPD - Glomerulonefrite proliferativa difusa; HAS - Hipertensão arterial sistêmica; HPV - Papiloma vírus humano; ITU - Infecção do trato urinário ; IVAS - Infecção das vias aéreas superiores; LED - Lúpus eritematoso discóide ; LES - Lúpus eritematoso sistêmico ; MIE Membro inferior esquerdo; SAAF - Síndrome do anticorpo antifosfolipídio; SAF - Síndrome antifosfolipídica; Sd. - Síndrome; SNC - Sistema nervosa central; TEP - Tromboembolismo pulmonar; TVP - Trombose venosa profunda 
APÊNDICE 2

Plataforma Brasil - Ministério da Saúde

Hospital das Clínicas da Faculdade de Medicina de Ribeirão Preto da USP - HCFMRP/USP

PROJETO DE PESQUISA

\begin{tabular}{|c|c|}
\hline \multicolumn{2}{|c|}{ Título: CNVs em pacientes com Lúpus Eritematoso Sistêmico } \\
\hline \multicolumn{2}{|c|}{ Área Temática: } \\
\hline Pesquisador: Fernanda Bueno Barbosa & Versäo: 2 \\
\hline $\begin{array}{c}\text { Instituição: Faculdade de Medicina de Ribeiräo Preto da } \\
\text { Universidade de Säo Paulo }\end{array}$ & CAAE: 03199712.0 .0000 .5440 \\
\hline \multicolumn{2}{|c|}{ PARECER CONSUBSTANCIADO DO CEP } \\
\hline
\end{tabular}

Número do Parecer: 72493

Data da Relatoria: $\quad 08 / 09 / 2012$

\section{Apresentação do Projeto:}

Identificaçäo: projeto de pesquisa de mestrado a ser desenvolvido pela pesquisadora Fernanda Bueno Barbosa, graduada em ciências biológicas, sob orientação do Prof. Dr. Aguinaldo Luiz Simões.

\section{Objetivo da Pesquisa:}

O presente trabalho tem como objetivo geral promover uma análise em larga escala da existência da relação entre as CNVs com o risco de ocorrència de LES em amostras de população brasileira, o que permitirá atingir os seguintes objetivos específicos:

1. Comparar as CNVs encontradas em indivíduos saudáveis com as encontradas nos pacientes com LES:

2. Estimar a frequència em das CNVs identificadas;

3. Identificar novas CNVs no conjunto amostral.

\section{Avaliação dos Riscos e Beneficios:}

Como uma avaliaçäo dos possíveis benefícios decorrentes do desenvolvimento da pesquisa em tela, os pesquisadores afirmam que näo há previsäo de benefícios individuais aos doadores de amostras para realização deste projeto de pesquisa, entretanto, os resultados da pesquisa podem fornecer subsídio para compreensäo das bases genéticas da doença e dos processos autoimunes.

A questão dos possíveis riscos foi abordada no relatório de pesquisa.

\section{Comentários e Consideraçöes sobre a Pesquisa:}

O genoma humano varia entre os indivíduos não somente ao nivel de sequencia, mas também estruturalmente. Duplicaçöes e deleçöes podem resultar em alteraçöes no número de cópias diploide dos segmentos genômicos. Isto é referido como variação no número de cópias (CNVs). As CNVs podem contribuir para a variabilidade do risco na etiologia das doenças complexas entre os indivíduos. A evidência disponivel sugere que exista variaçäo

em pelo menos 20 loci associados ao Lúpus Eritematoso Sistêmico (LES) que contribuem para a susceptibilidade à patogênese. Recentes estudos de associaçäo genómica em larga escala (GWAS)confirmaram loci previamente associados com LES, além de revelarem novas regiöes gênicas relacionadas com a doença (Morris et al., 2010; Sanchez et al., 2011; Yu et al., 2011). Embora tenha ocorrido um progresso notável tanto em ensaios iniciais de GWAS e em estudos de genes alvo do LES, ainda existem lacunas significativas na compreensäo da base genética da doença. Em termos de perspectivas futuras, 0 modelo de GWAS tem as suas limitaçöes. Como esses estudos são baseados na associaçäo com blocos haplotípicos

comuns, pode ocorrer a deteç̧äo de um marcador em forte desequilíbrio de ligação com a variante causal ao invés de identificar a variante causal real (Sanchez et al., 2011). A identificaçäo recente de CNVs comuns no genoma humano como fonte de modificaçäo genética pode explicar, em parte, a susceptibilidade à autoimunidade (Bronstad et al., 2011).METODOLOGIA: Neste projeto será analisado o perfil de CNVs de pacientes portadores de LES e um grupo controle de indivíduos saudáveis. Para isso, será realizado um ensaio de microarranjo, por meio da metodologia de SNP array. Seräo estudados 24 pacientes e número equivalente de controles. O DNA de tais amostras se encontra extraído, uma vez que estas foram 
utilizadas em outros projetos já executados ou em execuçāo, todos previamente aprovados por Comissāo de Ética. A delecçāo de variantes no número de cópias será realizada com a utilizaçāo da plataforma Affymetrix GeneChip System(1) (CyıScan HD), que permite a tipagem 2,6 milhōes de CNVs e 700 mil SNPs. A leitura será feita pelo software Chromosome Analysis Suite (ChAS) e os dados gerados serāo comparados com os bancos de dados disponiveis online. A determinaçāo do padrāo de CNVs para o grupo de pacientes e de

controles inclui identificar as CNVs comuns, raras e novas. As frequências das CNVs relevantes encontradas nos pacientes serāo comparadas com aquelas encontradas nos individuos saudáveis. As amostras dos pacientes portadores de LES foram anteriormente coletadas, mediante consentimento prévio, de pacientes atendidos e diagnosticados no ambulatório de Colagenases da Clínica Médica da Faculdade de Medicina de Ribeirāo Preto (HCFMRP, USP) para o projeto de pesquisa ¿Estudo da Neutropenia Em Pacientes Com Lúpus Eritematoso Sistêmicoz, com o Professor Doutor Eduardo Antônio Donadi como res ponsável. O grupo controle foi escolhido entre as amostras pertencentes a individuos saudáveis, voluntários, nāo aparentados, de ambos os sexos, residentes da cidade de Ribeirāo Preto, aprovadas pelo projelo ¿ Tipagem de variantes nos genes associados à pigmentaçāo de peleż, com o Professor Doutor Celso Teixeira Mendes Jủnior como responsável.

\section{Consideraçōes sobre os Temos de apresentação obrig ató ria:}

Foram apresentados os seguintes documentos: a) Folha de rosto, assinada pela pesquisadora responsável e pelo Vice-Diretor da Faculdade de Medicina de Ribeirāo Preto z USP; b) Projeto de Pesquisa na íntegra, com o orçamento detalhado, referências bibliográficas atuais e pertinentes, e cronograma coerente; c) carta de solicitaçāo de dispensa do Termo de Consentimento Livre e Esclarecido; d) anuência dos docentes Prof. Dr. Eduardo Antonio Donadi e Prof. Dr. Celso Teixeira Mendes para utilizaçāo das amostras.

\section{Recomendaçōes:}

Sem novas recomendaç̄es.

\section{Conclusōes ou Pendências e Lista de Inadequaçōes:}

Aprovado

\section{Situação do Parecer:}

Aprovado

\section{Necessita Apreciaçäo da CONEP:}

Nāo

\section{Consideraçōes Finais a critério do CEP:}

Projeto Aprovado: Tendo em vista a legislaçāo vigente, devem ser encaminhados ao CEP, relatórios parciais anuais referentes ao andamento da pesquisa e relatório final ao término do trabalho. Qualquer modificaçāo do projeto original deve ser apresentada a este CEP, de forma objetiva e com justificativas, para nova apreciaçāo.

RIBEIRAO PRETO, 13 de Agosto de 2012 
Apêndice 3. Listas de genes incluídos nas Cytoregions no programa ChAS

Lista 1: Genes relacionados com autoimunidade

\begin{tabular}{|c|c|c|}
\hline Gene & Cromossomo & Referência \\
\hline CDKAL1 & 1 & [1] \\
\hline FCGR1C & 1 & [2] \\
\hline FCGR3B & 1 & [3] \\
\hline IL23R & 1 & [4] \\
\hline ITLN1 & 1 & [1] \\
\hline MMEL1 & 1 & [5] \\
\hline PADI4 & 1 & [4] \\
\hline PTPN22 & 1 & [1] \\
\hline RGS1 & 1 & [1] \\
\hline ATG16L1 & 2 & [1] \\
\hline CTLA4 & 2 & [4] \\
\hline IFIH1 & 2 & [1] \\
\hline IL18RAP & 2 & [1] \\
\hline LRP1B & 2 & [2] \\
\hline REL & 2 & [4] \\
\hline STAT4 & 2 & [4] \\
\hline CCR3 & 3 & [1] \\
\hline H1FOO & 3 & [2] \\
\hline IL12A & 3 & [1] \\
\hline LPP & 3 & [1] \\
\hline MST1 & 3 & [1] \\
\hline PLXND1 & 3 & [2] \\
\hline PXK & 3 & [1] \\
\hline RHO & 3 & [2] \\
\hline TBC1D5 & 3 & [2] \\
\hline IL2-IL21 & 4 & [1] \\
\hline NFKB1 & 4 & [5] \\
\hline UGT2B17 & 4 & [2] \\
\hline UGT2B28 & 4 & [2] \\
\hline CCR6 & 5 & [1] \\
\hline HSD17B4 & 5 & [2] \\
\hline IL12B & 5 & [1] \\
\hline PTGER4 & 5 & [1] \\
\hline C13orf31 & 6 & [1] \\
\hline C4A & 6 & [3] \\
\hline C4B & 6 & [3] \\
\hline JAK2 & 6 & [1] \\
\hline TNFAIP3 & 6 & [1] \\
\hline BMPER & 7 & [2] \\
\hline
\end{tabular}

\begin{tabular}{|c|c|c|}
\hline Gene & Cromossomo & Referência \\
\hline IRF5 & 7 & [4] \\
\hline NCF1 & 7 & [3] \\
\hline ORMDL3 & 7 & [1] \\
\hline TYW1 & 7 & [6] \\
\hline ADAM3A & 8 & [2] \\
\hline BLK & 8 & [4] \\
\hline SCARA5 & 8 & [2] \\
\hline SNTG1 & 8 & [6] \\
\hline STAT3 & 8 & [1] \\
\hline ICOSLG & 9 & [1] \\
\hline TRAF1-C5 & 9 & [1] \\
\hline IL2RA & 10 & [1] \\
\hline NKX2-3 & 10 & [1] \\
\hline ZNF365 & 10 & [1] \\
\hline CXCR5 & 11 & [5] \\
\hline INS & 11 & [4] \\
\hline ANKS1B & 12 & [6] \\
\hline ERBB3 & 12 & [1] \\
\hline LRRK2 & 12 & [1] \\
\hline RASSF9 & 12 & [2] \\
\hline SH2B3 & 12 & [1] \\
\hline NFKBIA & 14 & [2] \\
\hline TSHR & 14 & [4] \\
\hline BCL8 & 15 & [6] \\
\hline GOLGA6L6 & 15 & [6] \\
\hline GOLGA8C & 15 & [6] \\
\hline POTEB & 15 & [6] \\
\hline CLEC16A & 16 & [1] \\
\hline ITGAM & 16 & [1] \\
\hline NOD2 & 16 & [4] \\
\hline CCL3L1 & 17 & [3] \\
\hline KIAA1267 & 17 & [2] \\
\hline TRIM16 & 17 & [6] \\
\hline PTPN2 & 18 & [1] \\
\hline SPIB & 19 & [5] \\
\hline CD40 & 20 & [4] \\
\hline AIRE & 21 & [4] \\
\hline FOXP3 & $x$ & [4] \\
\hline
\end{tabular}


Lista 2: Genes relacionados com LES

\begin{tabular}{|c|c|c|}
\hline Gene & Cromossomo & Referência \\
\hline C1Q & 1 & [7] \\
\hline CFHR1-5 & 1 & [8] \\
\hline CRP & 1 & [8] \\
\hline FCGR & 1 & [9] \\
\hline FCGR2A & 1 & [8] \\
\hline FCGR3B & 1 & [8] \\
\hline IL10 & 1 & [8] \\
\hline NCF2 & 1 & [9] \\
\hline NMNAT2 & 1 & [8] \\
\hline PTPN22 & 1 & [9] \\
\hline TNFSF4 & 1 & [9] \\
\hline CD28 & 2 & [10] \\
\hline CXCR4 & 2 & [10] \\
\hline IFIH1 & 2 & [9] \\
\hline IL1RN & 2 & [10] \\
\hline PDCD1 & 2 & [7] \\
\hline RASGRP3 & 2 & [9] \\
\hline STAT1 & 2 & [7] \\
\hline STAT4 & 2 & [9] \\
\hline PXK & 3 & [9] \\
\hline TREX1 & 3 & [8] \\
\hline BANK1 & 4 & [9] \\
\hline IL2 & 4 & [8] \\
\hline IL21 & 4 & [8] \\
\hline IL4 & 5 & [10] \\
\hline MIR146A & 5 & [8] \\
\hline TNIP1 & 5 & [9] \\
\hline ATG5 & 6 & [9] \\
\hline $\mathrm{C2}$ & 6 & [7] \\
\hline C4A & 6 & [7] \\
\hline C4B & 6 & [7] \\
\hline HLA & 6 & [8] \\
\hline PRDM1 & 6 & [9] \\
\hline
\end{tabular}

\begin{tabular}{|c|c|c|}
\hline Gene & Cromossomo & Referência \\
\hline TNFAIP3 & 6 & [9] \\
\hline UHRF1BP1 & 6 & [9] \\
\hline ICA1 & 7 & [8] \\
\hline IKZF1 & 7 & [9] \\
\hline IL6 & 7 & [10] \\
\hline IRF5 & 7 & [9] \\
\hline JAZF1 & 7 & [9] \\
\hline BLK & 8 & [9] \\
\hline FAM167A & 8 & [7] \\
\hline IKBKB & 8 & [8] \\
\hline LYN & 8 & [9] \\
\hline XKR6 & 8 & [9] \\
\hline LRRC18 & 10 & [9] \\
\hline WDFY4 & 10 & [9] \\
\hline CD44 & 11 & [9] \\
\hline ETS1 & 11 & [9] \\
\hline IRF7 & 11 & [9] \\
\hline KIAA1542 & 11 & [8] \\
\hline PHRF1 & 11 & [8] \\
\hline SLC15A4 & 12 & [9] \\
\hline ELF1 & 13 & [8] \\
\hline IRF8 & 16 & [9] \\
\hline ITGAM & 16 & [9] \\
\hline PRKCB & 16 & [8] \\
\hline TYK2 & 19 & [9] \\
\hline CD40 & 20 & [8] \\
\hline UBE2L3 & 22 & [9] \\
\hline IRAK1 & $x$ & [8] \\
\hline MECP2 & $x$ & [8] \\
\hline TLR7 & $\mathrm{x}$ & [8] \\
\hline
\end{tabular}




\begin{tabular}{lrl}
\hline \multicolumn{1}{c}{ Gene } & Cromossomo & Referência \\
\hline FCGR3B & 1 & {$[11,12,13]$} \\
IL-21 & 4 & {$[14]$} \\
C4A & 6 & {$[15,16]$} \\
C4B & 6 & {$[15,16]$} \\
IL-17F & 6 & {$[14]$} \\
IL-22 & 12 & {$[14]$} \\
\hline
\end{tabular}

\section{$\underline{\text { Referências das listas }}$}

1. Lettre, G. and J.D. Rioux, Autoimmune diseases: insights from genome-wide association studies. Human molecular genetics, 2008. 17(R2): p. R116-R121.

2. Bronstad, I., et al., Genome-wide copy number variation (CNV) in patients with autoimmune Addison's disease. BMC medical genetics, 2011. 12(1): p. 111.

3. Olsson, L.M. and R. Holmdahl, Copy number variation in autoimmunity: importance hidden in complexity? European Journal of Immunology, 2012. 42(8): p. 19691976.

4. Gregersen, P.K. and T.W. Behrens, Genetics of autoimmune disease: disorders of immune homeostasis. Nature Reviews Genetics, 2006. 7(12): p. 917-928.

5. Smyk, D.S., et al., Rheumatoid arthritis and primary biliary cirrhosis: cause, consequence, or coincidence? Arthritis, 2012. 2012.

6. Grayson, B.L., et al., Genome-wide analysis of copy number variation in type 1 diabetes. PloS one, 2010. 5(11): p. e15393.

7. Harley, I.T.W., et al., Genetic susceptibility to SLE: new insights from fine mapping and genome-wide association studies. Nature Reviews Genetics, 2009. 10(5): p. 285-290.

8. Vaughn, S.E., et al., Genetic susceptibility to lupus: the biological basis of genetic risk found in B cell signaling pathways. Journal of Leukocyte Biology, 2012. 92(3): p. 577-591.

9. Guerra, S.G., T.J. Vyse, and D.S.C. Graham, The genetics of lupus: a functional perspective. enzyme, 2012. 2: p. 3.

10. Chai, H.C., M.E. Phipps, and K.H. Chua, Genetic Risk Factors of Systemic Lupus Erythematosus in the Malaysian Population: A Minireview. Clinical and Developmental Immunology, 2012. 2012.

11. Molokhia, M., et al., FCGR3B copy number variation is associated with systemic lupus erythematosus risk in Afro-Caribbeans. Rheumatology, 2010. 50(7): p. 12061210. 
12. Morris, D.L., et al., Evidence for both copy number and allelic (NA1/NA2) risk at the FCGR3B locus in systemic lupus erythematosus. European Journal of Human Genetics, 2010. 18(9): p. 1027-1031.

13. Mueller, M., et al., Genomic Pathology of SLE-Associated Copy-Number Variation at the FCGR2C/FCGR3B/FCGR2BLocus. The American Journal of Human Genetics, 2013.

14. Yu, B., et al., Copy number variations of interleukina17F, interleukina 21, and interleukina 22 are associated with systemic lupus erythematosus. Arthritis \& Rheumatism, 2011. 63(11): p. 3487-3492.

15. Yang, Y., et al., Gene copy-number variation and associated polymorphisms of complement component C4 in human systemic lupus erythematosus (SLE): low copy number is a risk factor for and high copy number is a protective factor against SLE susceptibility in European Americans. The American Journal of Human Genetics, 2007. 80(6): p. 1037-1054.

16. Wu, Y., et al., Phenotypes, genotypes and disease susceptibility associated with gene copy number variations: complement C4 CNVs in European American healthy subjects and those with systemic lupus erythematosus. Cytogenetic and genome research, 2008. 123(1-4): p. 131-141. 
Apêndice 4. Tabela representando o total de CNVs detectadas nos pacientes com LES

\begin{tabular}{|c|c|c|c|c|c|c|c|c|c|c|}
\hline \multirow[b]{2}{*}{ CNV ID } & \multirow[b]{2}{*}{ Paciente } & \multicolumn{4}{|c|}{ Localização Genômica } & \multirow[b]{2}{*}{ Tipo } & \multirow[b]{2}{*}{ CN State } & \multirow{2}{*}{$\begin{array}{l}\text { Tamanho } \\
\text { (kb) }\end{array}$} & \multirow{2}{*}{$\begin{array}{c}\mathrm{N}^{\circ} \mathrm{de} \\
\text { marcadores }\end{array}$} & \multirow[b]{2}{*}{ Genes } \\
\hline & & Cromossomo & Citobanda & Início & Fim & & & & & \\
\hline 1 & 1 & 1 & q44 & 248753332 & 248795277 & Deleção & 1 & 41,9 & 56 & OR2T10, OR2T11 \\
\hline 2 & 1 & 3 & p21.1 & 53031722 & 53038786 & Deleção & 1 & 7,1 & 32 & SFMBT1 \\
\hline 3 & 1 & 4 & q35.1 & 185799622 & 185860319 & Duplicação & 3 & 60,7 & 50 & - \\
\hline 4 & 1 & 8 & p11.22 & 39247097 & 39386952 & Deleção & 1 & 139,9 & 76 & ADAM5P, ADAM3A \\
\hline 5 & 1 & 10 & $\mathrm{q} 11.22$ & 46996612 & 47056291 & Duplicação & 3 & 59,7 & 59 & GPRIN2 \\
\hline 6 & 1 & 10 & q26.3 & 135228992 & 135377075 & Duplicação & 3 & 148,1 & 245 & $\begin{array}{l}\text { MTG1, SPRN, } \\
\text { LOC619207, CYP2E1, } \\
\text { SYCE1 }\end{array}$ \\
\hline 7 & 1 & 11 & p15.4 & 5783909 & 5809230 & Deleção & 1 & 25,3 & 48 & OR52N5, OR52N1 \\
\hline 8 & 1 & 11 & p15.1 & 18941196 & 18971367 & Duplicação & 3 & 30,2 & 68 & MRGPRX1 \\
\hline 9 & 1 & 11 & p11.12 & 49712522 & 49746642 & Deleção & 1 & 34,1 & 34 & LOC440040 \\
\hline 10 & 1 & 12 & p11.23 & 27646150 & 27659531 & Deleção & 1 & 13,4 & 28 & C12orf70 \\
\hline 11 & 1 & 14 & q32.33 & 106329183 & 106876355 & Duplicação & 3 & 547,2 & 120 & $\begin{array}{l}\text { KIAA0125, ADAM6, } \\
\text { NCRNA00226 }\end{array}$ \\
\hline 12 & 1 & 15 & $\mathrm{q} 11.2$ & 25430385 & 25420014 & Deleção & 1 & 10,4 & 29 & $\begin{array}{l}\text { SNORD115-3, } \\
\text { SNORD115-4, } \\
\text { SNORD115-5, } \\
\text { SNORD115-10, } \\
\text { SNORD115-12, } \\
\text { SNORD115-9, } \\
\text { SNORD115-6, } \\
\text { SNORD115-7, } \\
\text { SNORD115-8 }\end{array}$ \\
\hline
\end{tabular}




\begin{tabular}{|c|c|c|c|c|c|c|c|c|c|c|}
\hline 13 & 1 & 17 & q21.31 & 44190670 & 44288442 & Duplicação & 3 & 97,8 & 100 & KIAA1267, LOC644246 \\
\hline 14 & 1 & 19 & $\mathrm{q} 13.2$ & 41352688 & 41392142 & Deleção & 1 & 39,5 & 46 & CYP2A6, CYP2A7 \\
\hline 16 & 1 & $x$ & p22.33 & 1793059 & 1818776 & Duplicação & 3 & 25,7 & 52 & - \\
\hline 17 & 1 & $x$ & p11.22 & 53475174 & 53488727 & Deleção & 0 & 13,6 & 100 & - \\
\hline 18 & 2 & 1 & q44 & 248753332 & 248794396 & Deleção & 1 & 41,1 & 52 & OR2T10, OR2T11 \\
\hline 19 & 2 & 4 & $\mathrm{q} 28.3$ & 134924033 & 135191179 & Deleção & 1 & 267,1 & 159 & PABPC4L \\
\hline 20 & 2 & 5 & q35.3 & 180378753 & 180418090 & Deleção & 1 & 39,3 & 34 & BTNL3 \\
\hline 21 & 2 & 6 & p25.3 & 254253 & 294826 & Deleção & 1 & 40,6 & 88 & DUSP22 \\
\hline 22 & 2 & 8 & p11.22 & 39247097 & 39386952 & Deleção & 1 & 139,9 & 76 & ADAM5P, ADAM3A \\
\hline 24 & 2 & 14 & q32.33 & 106329183 & 106728149 & Duplicação & 3 & 399,0 & 72 & KIAA0125, ADAM6 \\
\hline 25 & 2 & 15 & q14 & 34929954 & 34975073 & Deleção & 1 & 45,1 & 43 & - \\
\hline 26 & 2 & 19 & p13.12 & 15777995 & 15820325 & Duplicação & 3 & 42,3 & 63 & CYP4F12 \\
\hline 27 & 2 & $x$ & $\mathrm{q} 27.1$ & 139493671 & 139504489 & Deleção & 0 & 10,8 & 72 & - \\
\hline 28 & 3 & 1 & $\mathrm{q} 21.3$ & 152761910 & 152773905 & Deleção & 1 & 12,0 & 28 & LCE1D \\
\hline 29 & 3 & 2 & p22.3 & 35926022 & 35997473 & Deleção & 1 & 71,5 & 40 & - \\
\hline 30 & 3 & 3 & $\mathrm{p} 21.31$ & 46780900 & 46813059 & Deleção & 1 & 32,2 & 40 & PRSS45 \\
\hline 31 & 3 & 3 & $\mathrm{q} 12.2$ & 100340054 & 100442497 & Duplicação & 3 & 102,4 & 108 & GPR128, TFG \\
\hline 32 & 3 & 3 & q24 & 145626200 & 145662453 & Deleção & 1 & 36,3 & 30 & - \\
\hline
\end{tabular}




\begin{tabular}{|c|c|c|c|c|c|c|c|c|c|c|}
\hline 33 & 3 & 3 & q28 & 189360266 & 189371964 & Deleção & 1 & 11,7 & 40 & TP63 \\
\hline 34 & 3 & 6 & q12 & 66399523 & 66407209 & Deleção & 1 & 7,7 & 28 & EYS \\
\hline 35 & 3 & 6 & q14.1 & 78962580 & 79035161 & Deleção & 1 & 72,6 & 25 & - \\
\hline 36 & 3 & 11 & q11 & 55374175 & 55452996 & Deleção & 1 & 78,8 & 96 & OR4P4, OR4S2, OR4C6 \\
\hline 37 & 3 & 13 & q21.1 & 57758376 & 57776590 & Deleção & 1 & 18,2 & 28 & - \\
\hline 38 & 3 & 14 & $\mathrm{q} 11.2$ & 22633667 & 22688302 & Deleção & 1 & 54,6 & 112 & - \\
\hline 39 & 3 & 14 & q11.2 & 22730927 & 22938126 & Deleção & 1 & 207,2 & 288 & - \\
\hline 40 & 3 & 14 & q32.33 & 106207204 & 106931309 & Duplicação & 3 & 724,1 & 266 & $\begin{array}{l}\text { KIAA0125, ADAM6, } \\
\text { NCRNA00226 }\end{array}$ \\
\hline 41 & 3 & 17 & q12 & 36283806 & 36404136 & Deleção & 1 & 120,3 & 28 & TBC1D3F, TBC1D3 \\
\hline 42 & 3 & 19 & q13.42 & 55283915 & 55347661 & Deleção & 1 & 63,7 & 28 & $\begin{array}{l}\text { KIR3DP1, KIR2DL1, } \\
\text { KIR2DL4, KIR3DL1, } \\
\text { KIR2DS4 }\end{array}$ \\
\hline 43 & 3 & $x$ & p22.33 & 784132 & 837407 & Deleção & 1 & 53,3 & 117 & - \\
\hline 44 & 3 & $x$ & p22.33 & 1793056 & 1818776 & Duplicação & 3 & 25,7 & 55 & - \\
\hline 45 & 3 & $x$ & q27.1 & 139493805 & 139504489 & Deleção & 0 & 10,7 & 60 & - \\
\hline 46 & 4 & 6 & q14.1 & 78962580 & 79035172 & Deleção & 1 & 72,6 & 26 & - \\
\hline 47 & 4 & 8 & p11.22 & 39247097 & 39386952 & Deleção & 1 & 139,9 & 76 & ADAM5P, ADAM3A \\
\hline 48 & 4 & 12 & q23.1 & 99791778 & 99798721 & Deleção & 1 & 6,9 & 32 & ANKS1B \\
\hline 49 & 4 & 14 & q32.33 & 106329183 & 106728149 & Duplicação & 3 & 399,0 & 72 & KIAA0125, ADAM6 \\
\hline 50 & 4 & 14 & q32.33 & 107150443 & 107184184 & Duplicação & 3 & 33,7 & 66 & - \\
\hline 51 & 5 & 1 & p31.3 & 68490069 & 68502895 & Deleção & 1 & 12,8 & 48 & - \\
\hline
\end{tabular}




\begin{tabular}{|c|c|c|c|c|c|c|c|c|c|c|}
\hline 52 & 5 & 1 & q21.3 & 152259841 & 152306921 & Deleção & 1 & 47,1 & 36 & FLG \\
\hline 53 & 5 & 2 & p16.3 & 50369634 & 50384213 & Deleção & 1 & 14,6 & 39 & NRXN1 \\
\hline 54 & 5 & 2 & q11.2 & 97858137 & 97878057 & Deleção & 1 & 19,9 & 28 & ANKRD36 \\
\hline 55 & 5 & 2 & q34 & 213163737 & 213178030 & Deleção & 1 & 14,3 & 72 & ERBB4 \\
\hline 56 & 5 & 3 & p24.1 & 28360091 & 28402320 & Deleção & 1 & 42,2 & 34 & CMC1, AZI2 \\
\hline 57 & 5 & 3 & p21.31 & 46793363 & 46849576 & Deleção & 1 & 56,2 & 47 & - \\
\hline 58 & 5 & 3 & p12.3 & 77565380 & 77577207 & Deleção & 1 & 11,8 & 27 & ROBO2 \\
\hline 59 & 5 & 3 & p12.2 & 81559499 & 81576967 & Deleção & 1 & 17,5 & 35 & GBE1 \\
\hline 60 & 5 & 4 & q13.2 & 69435888 & 69540420 & Deleção & 1 & 104,5 & 48 & UGT2B15 \\
\hline 61 & 5 & 5 & p12 & 45915731 & 46365514 & Deleção & 1 & 449,8 & 130 & - \\
\hline 63 & 5 & 5 & q33.2 & 154834014 & 154878178 & Deleção & 1 & 44,2 & 40 & - \\
\hline 64 & 5 & 6 & p25.3 & 1966835 & 2071120 & Duplicação & 3 & 104,3 & 123 & GMDS \\
\hline 65 & 5 & 6 & p21.32 & 32688023 & 32708890 & Deleção & 1 & 20,9 & 48 & - \\
\hline 66 & 5 & 6 & q12 & 64685861 & 64703901 & Deleção & 1 & 18,0 & 33 & EYS \\
\hline 67 & 5 & 6 & q12 & 65037075 & 65068777 & Deleção & 1 & 31,7 & 28 & EYS \\
\hline 68 & 5 & 6 & q14.1 & 78962625 & 79060009 & Deleção & 1 & 97,4 & 43 & - \\
\hline 69 & 5 & 6 & q14.1 & 82406876 & 82426708 & Deleção & 1 & 19,8 & 32 & - \\
\hline 70 & 5 & 6 & q16.1 & 94032409 & 94058581 & Deleção & 1 & 26,2 & 46 & EPHA7 \\
\hline 71 & 5 & 7 & p21.3 & 8576628 & 8601956 & Deleção & 1 & 25,3 & 27 & NXPH1 \\
\hline
\end{tabular}




\begin{tabular}{|c|c|c|c|c|c|c|c|c|c|c|}
\hline 72 & 5 & 7 & p21.3 & 8824416 & 8865997 & Deleção & 1 & 41,6 & 40 & - \\
\hline 73 & 5 & 7 & q31.1 & 114209440 & 114215739 & Deleção & 1 & 6,3 & 28 & FOXP2 \\
\hline 74 & 5 & 8 & p22 & 15517524 & 15530708 & Deleção & 1 & 13,2 & 28 & TUSC3 \\
\hline 75 & 5 & 8 & p11.22 & 39247097 & 39352609 & Deleção & 1 & 105,5 & 52 & ADAM5P, ADAM3A \\
\hline 76 & 5 & 8 & p11.1 & 43424102 & 43736876 & Deleção & 1 & 312,8 & 82 & - \\
\hline 77 & 5 & 8 & q11.1 & 47259429 & 47457980 & Deleção & 1 & 198,6 & 67 & - \\
\hline 78 & 5 & 9 & p21.1 & 31185861 & 31206711 & Deleção & 1 & 20,9 & 39 & - \\
\hline 79 & 5 & 9 & q33.1 & 121984102 & 121996379 & Deleção & 1 & 12,3 & 40 & DBC1 \\
\hline 80 & 5 & 9 & $q 34.2$ & 137354612 & 137529641 & Duplicação & 3 & 175,0 & 133 & - \\
\hline 81 & 5 & 10 & q21.1 & 58330866 & 58482756 & Deleção & 1 & 151,9 & 120 & - \\
\hline 83 & 5 & 11 & p11.2 & 48783129 & 48892181 & Deleção & 1 & 109,1 & 28 & - \\
\hline 84 & 5 & 11 & p11.12 & 50344786 & 51267021 & Deleção & 1 & 922,2 & 129 & LOC646813 \\
\hline 85 & 5 & 11 & q11 & 55376497 & 55442305 & Deleção & 1 & 65,8 & 72 & OR4P4, OR4S2, OR4C6 \\
\hline 86 & 5 & 11 & q14.1 & 84159356 & 84183411 & Deleção & 1 & 24,1 & 28 & DLG2 \\
\hline 87 & 5 & 11 & q25 & 134922399 & 134938470 & Deleção & 1 & 16,1 & 26 & - \\
\hline 88 & 5 & 12 & p13.1 & 13859810 & 13885432 & Deleção & 1 & 25,6 & 32 & GRIN2B \\
\hline 89 & 5 & 12 & $\mathrm{p} 11.1$ & 34559318 & 34749005 & Deleção & 1 & 189,7 & 40 & - \\
\hline 90 & 5 & 12 & q21.33 & 91442500 & 91454575 & Deleção & 1 & 12,1 & 32 & KERA \\
\hline 91 & 5 & 12 & $q 23.1$ & 99791638 & 99798721 & Deleção & 1 & 7,1 & 34 & ANKS1B \\
\hline
\end{tabular}




\begin{tabular}{|c|c|c|c|c|c|c|c|c|c|c|}
\hline 92 & 5 & 13 & q31.3 & 93378273 & 93386333 & Deleção & 1 & 8,1 & 32 & GPC5 \\
\hline 93 & 5 & 13 & q31.3 & 94506273 & 94515199 & Deleção & 1 & 8,9 & 55 & GPC6 \\
\hline 95 & 5 & 15 & q15.3 & 43888261 & 43984930 & Deleção & 1 & 96,7 & 76 & $\begin{array}{l}\text { CKMT1B, STRC, } \\
\text { CATSPER2 }\end{array}$ \\
\hline 96 & 5 & 16 & p13.3 & 3223992 & 3323432 & Duplicação & 3 & 99,4 & 123 & $\begin{array}{l}\text { OR1F1, OR1F2P, ZNF200, } \\
\text { MEFV, FLJ39639 }\end{array}$ \\
\hline 97 & 5 & 17 & q12 & 36283806 & 36410559 & Deleção & 1 & 126,8 & 32 & TBC1D3F, TBC1D3 \\
\hline 98 & 5 & 17 & q21.31 & 44212823 & 44784639 & Duplicação & 3 & 571,8 & 72 & $\begin{array}{l}\text { KIAA1267, LOC644246, } \\
\text { LRRC37A, ARL17A, } \\
\text { ARL17B, NSFP1, } \\
\text { LRRC37A2, NSF }\end{array}$ \\
\hline 99 & 5 & $x$ & p22.33 & 1793059 & 1818776 & Duplicação & 3 & 25,7 & 52 & - \\
\hline 101 & 5 & $x$ & q28 & 153421784 & 153437615 & Deleção & 0 & 15,8 & 30 & OPN1LW \\
\hline 102 & 6 & 1 & $\mathrm{q} 24.2$ & 167675707 & 167705358 & Deleção & 1 & 29,7 & 28 & MPZL1 \\
\hline 103 & 6 & 3 & p21.31 & 46801991 & 46832069 & Deleção & 1 & 30,1 & 33 & - \\
\hline 104 & 6 & 6 & p25.3 & 254253 & 294826 & Deleção & 1 & 40,6 & 88 & DUSP22 \\
\hline 105 & 6 & 6 & q12 & 67011364 & 67051189 & Deleção & 1 & 39,8 & 28 & - \\
\hline 106 & 6 & 7 & $\mathrm{p} 22.3$ & 154720 & 158615 & Deleção & 0 & 3,9 & 28 & - \\
\hline 107 & 6 & 8 & p11.22 & 39247097 & 39386952 & Deleção & 0 & 139,9 & 76 & ADAM5P, ADAM3A \\
\hline 108 & 6 & 11 & p15.4 & 5783909 & 5812365 & Deleção & 1 & 28,5 & 52 & OR52N5, OR52N1 \\
\hline 109 & 6 & 11 & q11 & 55376497 & 55442305 & Deleção & 1 & 65,8 & 72 & OR4P4, OR4S2, OR4C6 \\
\hline
\end{tabular}




\begin{tabular}{|c|c|c|c|c|c|c|c|c|c|c|}
\hline 110 & 6 & 14 & q32.33 & 106274525 & 106728149 & Duplicação & 3 & 453,6 & 138 & KIAA0125, ADAM6 \\
\hline 111 & 6 & 15 & $\mathrm{q} 11.2$ & 24363482 & 24485873 & Deleção & 1 & 122,4 & 105 & PWRN2 \\
\hline 113 & 6 & $x$ & p22.33 & 354464 & 401509 & Duplicação & 3 & 47,0 & 64 & - \\
\hline 114 & 7 & 1 & q31.3 & 196827841 & 196877037 & Deleção & 1 & 49,2 & 60 & CFHR4 \\
\hline 115 & 7 & 1 & q44 & 248753183 & 248794396 & Deleção & 1 & 41,2 & 54 & OR2T10, OR2T11 \\
\hline 116 & 7 & 8 & p11.22 & 39247097 & 39384956 & Deleção & 1 & 137,9 & 74 & ADAM5P, ADAM3A \\
\hline 117 & 7 & 9 & q34.3 & 138139988 & 138240551 & Duplicação & 3 & 100,6 & 58 & - \\
\hline 118 & 7 & 11 & p11.12 & 50480770 & 51228126 & Deleção & 1 & 747,4 & 52 & - \\
\hline 120 & 7 & 15 & $\mathrm{q} 11.2$ & 25421329 & 25430243 & Deleção & 1 & 8,9 & 26 & $\begin{array}{l}\text { SNORD115-4, } \\
\text { SNORD115-5, } \\
\text { SNORD115-10, } \\
\text { SNORD115-12, } \\
\text { SNORD115-9, } \\
\text { SNORD115-6, } \\
\text { SNORD115-7, } \\
\text { SNORD115-8 }\end{array}$ \\
\hline 121 & 7 & 16 & $\mathrm{q} 12.2$ & 55796375 & 55821956 & Deleção & 1 & 25,6 & 29 & CES1P1 \\
\hline 122 & 7 & 17 & q21.2 & 39517068 & 39526296 & Deleção & 1 & 9,2 & 28 & KRT33B \\
\hline 123 & 7 & 17 & q21.31 & 44187491 & 44784639 & Duplicação & 4 & 597,1 & 108 & $\begin{array}{l}\text { KIAA1267, LOC644246, } \\
\text { LRRC37A, ARL17A, } \\
\text { ARL17B, NSFP1, } \\
\text { LRRC37A2, NSF }\end{array}$ \\
\hline 124 & 7 & 19 & $q 13.2$ & 41352688 & 41376007 & Deleção & 1 & 23,3 & 41 & CYP2A6 \\
\hline
\end{tabular}




\begin{tabular}{|c|c|c|c|c|c|c|c|c|c|c|}
\hline 125 & 7 & 20 & $\mathrm{q} 13.2$ & 52652464 & 52658506 & Deleção & 1 & 6,0 & 26 & BCAS1 \\
\hline 126 & 7 & $x$ & p22.31 & 6634452 & 6642670 & Deleção & 1 & 8,2 & 28 & - \\
\hline 128 & 7 & $x$ & $\mathrm{q} 26.3$ & 134874630 & 134891198 & Deleção & 1 & 16,6 & 28 & CТ45A4, СТ45АЗ \\
\hline 129 & 8 & 2 & q34 & 213181329 & 213192832 & Deleção & 1 & 11,5 & 39 & ERBB4 \\
\hline 130 & 8 & 3 & p21.31 & 46801803 & 46849576 & Deleção & 1 & 47,8 & 46 & - \\
\hline 131 & 8 & 5 & p15.31 & 6325587 & 6328043 & Deleção & 1 & 2,5 & 28 & FLJ33360 \\
\hline 132 & 8 & 9 & q21.11 & 72098584 & 72127165 & Duplicação & 3 & 28,6 & 72 & APBA1 \\
\hline 133 & 8 & 12 & $\mathrm{p} 13.2$ & 11219929 & 11251861 & Deleção & 1 & 31,9 & 37 & PRR4, PRH1, TAS2R43 \\
\hline 134 & 8 & 13 & $\mathrm{q} 21.1$ & 57750940 & 57776590 & Deleção & 1 & 25,7 & 36 & - \\
\hline 136 & 8 & 14 & q32.33 & 106329183 & 106709974 & Duplicação & 3 & 380,8 & 56 & KIAA0125, ADAM6 \\
\hline 137 & 8 & 17 & q21.31 & 44212823 & 44276618 & Duplicação & 3 & 63,8 & 64 & KIAA1267, LOC644246 \\
\hline 138 & 8 & 22 & $\mathrm{q} 12.1$ & 29079237 & 29115517 & Duplicação & 3 & 36,3 & 52 & CHEK2 \\
\hline 139 & 8 & $x$ & p22.33 & 2521636 & 2533169 & Deleção & 1 & 11,5 & 26 & CD99P1 \\
\hline 140 & 8 & $x$ & $\mathrm{q} 26.1$ & 129375241 & 129376465 & Deleção & 1 & 1,2 & 28 & ZNF280C \\
\hline 141 & 8 & $x$ & $\mathrm{q} 27.1$ & 139919015 & 139920849 & Deleção & 1 & 1,8 & 36 & - \\
\hline 142 & 8 & $x$ & q28 & 147317018 & 147324256 & Deleção & 1 & 7,2 & 26 & - \\
\hline 143 & 9 & 3 & p11.1 & 89387087 & 89419367 & Deleção & 1 & 32,4 & 50 & EPHA3 \\
\hline 144 & 9 & 5 & q15 & 96625630 & 96865984 & Deleção & 1 & 240,4 & 148 & - \\
\hline
\end{tabular}




\begin{tabular}{|c|c|c|c|c|c|c|c|c|c|c|}
\hline 145 & 9 & 5 & q35.3 & 180378753 & 180430789 & Deleção & 1 & 52,0 & 36 & BTNL3 \\
\hline 146 & 9 & 6 & p25.3 & 254253 & 381137 & Duplicação & 3 & 126,9 & 228 & DUSP22 \\
\hline 148 & 9 & 11 & p15.1 & 18941196 & 18971367 & Duplicação & 3 & 30,2 & 68 & MRGPRX1 \\
\hline 149 & 9 & 14 & q32.33 & 106329183 & 106717343 & Duplicação & 3 & 388,2 & 64 & KIAA0125, ADAM6 \\
\hline 150 & 9 & 14 & q32.33 & 107150443 & 107179594 & Duplicação & 3 & 29,2 & 64 & - \\
\hline 151 & 9 & 16 & $\mathrm{p} 11.2$ & 32554241 & 33754119 & Duplicação & 3 & $1.199,9$ & 120 & $\begin{array}{l}\text { TP53TG3B, TP53TG3, } \\
\text { SLC6A10P, LOC390705 }\end{array}$ \\
\hline 152 & 9 & 20 & $\mathrm{p} 11.21$ & 23727144 & 23796651 & Deleção & 1 & 69,5 & 85 & CST1 \\
\hline 153 & 9 & $x$ & q28 & 147115311 & 147117511 & Deleção & 1 & 2,2 & 40 & - \\
\hline 154 & 10 & 2 & $\mathrm{q} 21.2$ & 133280686 & 133317266 & Duplicação & 3 & 36,6 & 52 & GPR39 \\
\hline 155 & 10 & 2 & q33.1 & 203293011 & 203313469 & Deleção & 1 & 20,5 & 96 & BMPR2 \\
\hline 156 & 10 & 6 & $\mathrm{q} 14.1$ & 78866468 & 79051614 & Duplicação & 3 & 185,1 & 112 & - \\
\hline 157 & 10 & 6 & q25.1 & 152303218 & 152311895 & Deleção & 1 & 8,7 & 31 & ESR1 \\
\hline 158 & 10 & 7 & $\mathrm{p} 22.3$ & 154720 & 158615 & Deleção & 1 & 3,9 & 28 & - \\
\hline 159 & 10 & 7 & q21.11 & 85522989 & 85709099 & Deleção & 1 & 186,1 & 112 & - \\
\hline 160 & 10 & 7 & q35 & 146859536 & 146868357 & Deleção & 1 & 8,8 & 28 & CNTNAP2 \\
\hline 161 & 10 & 8 & p11.22 & 39247097 & 39386952 & Deleção & 1 & 139,9 & 76 & ADAM5P, ADAM3A \\
\hline 162 & 10 & 10 & $\mathrm{q} 26.3$ & 135357299 & 135427143 & Duplicação & 3 & 69,8 & 83 & SYCE1, SPRNP1 \\
\hline 163 & 10 & 11 & p15.4 & 5783909 & 5809230 & Deleção & 1 & 25,3 & 48 & OR52N5, OR52N1 \\
\hline 164 & 10 & 11 & p15.4 & 7809464 & 7837000 & Deleção & 1 & 27,5 & 28 & OR5P2 \\
\hline
\end{tabular}




\begin{tabular}{|c|c|c|c|c|c|c|c|c|c|c|}
\hline 165 & 10 & 12 & $\mathrm{p} 11.21$ & 31265043 & 31407111 & Duplicação & 3 & 142,1 & 56 & - \\
\hline 166 & 10 & 14 & q32.33 & 106329183 & 106849677 & Duplicação & 3 & 520,5 & 108 & $\begin{array}{l}\text { KIAA0125, ADAM6, } \\
\text { NCRNA00226 }\end{array}$ \\
\hline 167 & 10 & 19 & p13.12 & 15779310 & 15833442 & Duplicação & 3 & 54,1 & 67 & CYP4F12 \\
\hline 168 & 10 & $x$ & p22.2 & 10630413 & 10632537 & Deleção & 1 & 2,1 & 72 & MID1 \\
\hline 169 & 10 & $x$ & q23 & 115138899 & 115156164 & Deleção & 1 & 17,3 & 28 & - \\
\hline 170 & 10 & $x$ & $\mathrm{q} 26.3$ & 134928992 & 134966528 & Duplicação & 4 & 37,5 & 104 & СТ45A4, СТ45А5, СТ45А6 \\
\hline 171 & 11 & 1 & q44 & 248759244 & 248795277 & Deleção & 1 & 36,0 & 44 & OR2T11 \\
\hline 172 & 11 & 3 & p21.31 & 46793363 & 46849576 & Deleção & 1 & 56,2 & 47 & - \\
\hline 173 & 11 & 6 & p25.3 & 257048 & 294826 & Deleção & 1 & 37,8 & 86 & DUSP22 \\
\hline 174 & 11 & 6 & p25.3 & 294910 & 381137 & Duplicação & 3 & 86,2 & 140 & DUSP22 \\
\hline 175 & 11 & 6 & $\mathrm{q} 14.1$ & 78969091 & 79041720 & Deleção & 1 & 72,6 & 26 & - \\
\hline 176 & 11 & 8 & p12 & 30079990 & 30202711 & Duplicação & 3 & 122,7 & 92 & - \\
\hline 177 & 11 & 8 & p11.22 & 39258175 & 39384337 & Deleção & 1 & 126,2 & 60 & ADAM5P, ADAM3A \\
\hline 178 & 11 & 9 & p23 & 10546813 & 10586837 & Deleção & 1 & 40,0 & 92 & PTPRD \\
\hline 179 & 11 & 10 & q26.3 & 135371134 & 135427143 & Duplicação & 3 & 56,0 & 69 & SYCE1, SPRNP1 \\
\hline 180 & 11 & 11 & p15.4 & 5788078 & 5809230 & Deleção & 0 & 21,2 & 44 & OR52N5, OR52N1 \\
\hline 181 & 11 & 11 & q11 & 55402800 & 55452996 & Deleção & 1 & 50,2 & 76 & OR4P4, OR4S2, OR4C6 \\
\hline 182 & 11 & 12 & p12.1 & 21796951 & 22445614 & Duplicação & 3 & 648,7 & 783 & $\begin{array}{l}\text { LDHB, KCNJ8, ABCC9, } \\
\text { CMAS, ST8SIA1 }\end{array}$ \\
\hline 183 & 11 & 14 & q32.33 & 106329183 & 106728149 & Duplicação & 3 & 399,0 & 72 & KIAA0125, ADAM6 \\
\hline
\end{tabular}




\begin{tabular}{|c|c|c|c|c|c|c|c|c|c|c|}
\hline 184 & 11 & 17 & $\mathrm{q} 12$ & 34447401 & 34465088 & Deleção & 1 & 17,7 & 36 & - \\
\hline 185 & 11 & 19 & p12 & 20588836 & 20711751 & Deleção & 1 & 122,9 & 81 & ZNF826P \\
\hline 186 & 11 & 22 & q13.33 & 51104037 & 51115526 & Deleção & 1 & 11,5 & 48 & SHANK3 \\
\hline 187 & 11 & $x$ & p22.33 & 1459623 & 1469501 & Deleção & 1 & 9,9 & 29 & IL3RA \\
\hline 188 & 11 & $x$ & p22.2 & 15723836 & 15831401 & Duplicação & 3 & 107,6 & 116 & CA5B, INE2, ZRSR2 \\
\hline 189 & 11 & $x$ & q26.3 & 134928992 & 134966528 & Duplicação & 4 & 37,5 & 104 & CT45A4, CT45A5, СT45A6 \\
\hline 190 & 11 & $x$ & q27.1 & 139804197 & 139806255 & Deleção & 1 & 2,1 & 36 & - \\
\hline 191 & 12 & 1 & q31.3 & 196964969 & 196987806 & Deleção & 1 & 22,8 & 26 & CFHR5 \\
\hline 192 & 12 & 1 & q44 & 248688586 & 248794396 & Deleção & 1 & 105,8 & 56 & $\begin{array}{l}\text { OR2T29, OR2T34, } \\
\text { OR2T10, OR2T11 }\end{array}$ \\
\hline 193 & 12 & 3 & p24.2 & 26046360 & 26169924 & Deleção & 1 & 123,6 & 64 & - \\
\hline 194 & 12 & 3 & q28 & 189363665 & 189371964 & Deleção & 1 & 8,3 & 32 & TP63 \\
\hline 195 & 12 & 7 & p22.3 & 154720 & 158615 & Deleção & 1 & 3,9 & 28 & - \\
\hline 196 & 12 & 7 & p21.3 & 11983316 & 12078163 & Duplicação & 3 & 94,8 & 88 & - \\
\hline 197 & 12 & 7 & q22.1 & 100976195 & 101122851 & Duplicação & 3 & 146,7 & 112 & EMID2 \\
\hline 198 & 12 & 8 & p11.22 & 39247097 & 39386952 & Deleção & 1 & 139,9 & 76 & ADAM5P, ADAM3A \\
\hline 199 & 12 & 11 & q11 & 55402800 & 55442305 & Deleção & 1 & 39,5 & 56 & OR4P4, OR4S2, OR4C6 \\
\hline 200 & 12 & 12 & p11.21 & 31356048 & 31407111 & Duplicação & 3 & 51,1 & 52 & - \\
\hline 201 & 12 & 17 & q21.31 & 44212823 & 44784639 & Duplicação & 3 & 571,8 & 72 & $\begin{array}{l}\text { KIAA1267, LOC644246, } \\
\text { LRRC37A, ARL17A, } \\
\text { ARL17B, NSFP1, } \\
\text { LRRC37A2, NSF }\end{array}$ \\
\hline 202 & 12 & 19 & q13.2 & 41352688 & 41376006 & Deleção & 1 & 23,3 & 40 & CYP2A6 \\
\hline
\end{tabular}




\begin{tabular}{|c|c|c|c|c|c|c|c|c|c|c|}
\hline 203 & 12 & $x$ & q26.3 & 134693544 & 134694402 & Deleção & 1 & 0,9 & 39 & DDX26B \\
\hline 204 & 12 & $\mathrm{x}$ & q28 & 147317018 & 147325589 & Deleção & 1 & 8,6 & 44 & - \\
\hline 205 & 13 & 5 & p11 & 46246499 & 46377314 & Deleção & 1 & 130,8 & 27 & - \\
\hline 206 & 13 & 5 & q35.3 & 180378753 & 180430789 & Deleção & 1 & 52,0 & 36 & BTNL3 \\
\hline 207 & 13 & 6 & p25.3 & 254282 & 294826 & Deleção & 1 & 40,5 & 87 & DUSP22 \\
\hline 208 & 13 & 7 & q22.1 & 100968362 & 101141867 & Duplicação & 3 & 173,5 & 140 & EMID2 \\
\hline 209 & 13 & 8 & p11.22 & 39247097 & 39386952 & Deleção & 0 & 139,9 & 76 & ADAM5P, ADAM3A \\
\hline 210 & 13 & 8 & q13.3 & 72210736 & 72216588 & Deleção & 1 & 5,9 & 26 & EYA1 \\
\hline 211 & 13 & 11 & p11.2 & 48658169 & 48844411 & Deleção & 1 & 186,2 & 40 & - \\
\hline 212 & 13 & 11 & q11 & 54701631 & 55039246 & Deleção & 1 & 337,6 & 112 & TRIM48 \\
\hline 214 & 13 & 14 & q32.33 & 106329183 & 106709974 & Duplicação & 4 & 380,8 & 56 & KIAA0125, ADAM6 \\
\hline 215 & 13 & 15 & q25.3 & 87830571 & 87878603 & Deleção & 1 & 48,0 & 44 & - \\
\hline 216 & 13 & 19 & p12 & 20588836 & 20830021 & Deleção & 1 & 241,2 & 192 & $\begin{array}{l}\text { ZNF826P, ZNF737, } \\
\text { ZNF626 }\end{array}$ \\
\hline 217 & 13 & 22 & q11.23 & 25066486 & 25112325 & Deleção & 1 & 45,8 & 40 & - \\
\hline 218 & 13 & $\mathrm{x}$ & p22.33 & 356232 & 401509 & Duplicação & 3 & 45,3 & 60 & - \\
\hline 219 & 13 & $\mathrm{X}$ & q26.1 & 129375241 & 129376465 & Deleção & 1 & 1,2 & 28 & ZNF280C \\
\hline 220 & 13 & $\mathrm{x}$ & q26.3 & 134718783 & 134739030 & Deleção & 1 & 20,2 & 72 & - \\
\hline 221 & 13 & $x$ & q26.3 & 134747838 & 134749413 & Deleção & 1 & 1,6 & 26 & - \\
\hline 222 & 14 & 3 & $\mathrm{q} 13.32$ & 118719894 & 118820510 & Duplicação & 4 & 100,6 & 96 & IGSF11 \\
\hline
\end{tabular}




\begin{tabular}{|c|c|c|c|c|c|c|c|c|c|c|}
\hline 223 & 14 & 3 & q28 & 189363665 & 189371964 & Deleção & 1 & 8,3 & 32 & TP63 \\
\hline 224 & 14 & 4 & q32.3 & 168808499 & 168992441 & Deleção & 1 & 183,9 & 108 & - \\
\hline 225 & 14 & 5 & q35.3 & 180378753 & 180418090 & Deleção & 1 & 39,3 & 34 & BTNL3 \\
\hline 226 & 14 & 6 & p25.3 & 254253 & 381137 & Deleção & 1 & 126,9 & 228 & DUSP22 \\
\hline 227 & 14 & 7 & p14.1 & 38325923 & 38349129 & Deleção & 1 & 23,2 & 52 & - \\
\hline 228 & 14 & 7 & q34 & 142466348 & 142485841 & Deleção & 0 & 19,5 & 40 & TRY6, PRSS2 \\
\hline 229 & 14 & 8 & p11.22 & 39247097 & 39389003 & Deleção & 1 & 141,9 & 80 & ADAM5P, ADAM3A \\
\hline 230 & 14 & 11 & p15.4 & 5783909 & 5809230 & Deleção & 1 & 25,3 & 48 & OR52N5, OR52N1 \\
\hline 231 & 14 & 14 & q11.2 & 22690190 & 22944507 & Deleção & 1 & 254,3 & 380 & - \\
\hline 232 & 14 & 14 & q32.33 & 106342422 & 106728149 & Duplicação & 3 & 385,7 & 70 & KIAA0125, ADAM6 \\
\hline 234 & 14 & 16 & q12.2 & 55796375 & 55816692 & Deleção & 1 & 20,3 & 28 & CES1P1 \\
\hline 235 & 14 & 17 & q21.31 & 44190670 & 44784639 & Duplicação & 3 & 594,0 & 104 & $\begin{array}{l}\text { KIAA1267, LOC644246, } \\
\text { LRRC37A, ARL17A, } \\
\text { ARL17B, NSFP1, } \\
\text { LRRC37A2, NSF }\end{array}$ \\
\hline 236 & 14 & $x$ & q22.3 & 107110721 & 107116799 & Deleção & 1 & 6,1 & 36 & MID2 \\
\hline 237 & 14 & $x$ & q26.1 & 129375241 & 129383108 & Deleção & 1 & 7,9 & 29 & ZNF280C \\
\hline 238 & 15 & 1 & q32.2 & 210604980 & 210612839 & Deleção & 1 & 7,9 & 30 & HHAT \\
\hline 239 & 15 & 4 & $q 13.2$ & 69435888 & 69540420 & Deleção & 0 & 104,5 & 48 & UGT2B15 \\
\hline 240 & 15 & 5 & q35.3 & 180378775 & 180418090 & Deleção & 1 & 39,3 & 33 & BTNL3 \\
\hline 241 & 15 & 6 & p21.31 & 35505363 & 35569236 & Duplicação & 3 & 63,9 & 58 & FKBP5 \\
\hline
\end{tabular}




\begin{tabular}{|c|c|c|c|c|c|c|c|c|c|c|}
\hline 242 & 15 & 7 & p22.3 & 154720 & 158615 & Deleção & 1 & 3,9 & 28 & - \\
\hline 243 & 15 & 7 & q31.1 & 111049866 & 111083053 & Deleção & 1 & 33,2 & 28 & IMMP2L \\
\hline 245 & 15 & 8 & p11.22 & 39247097 & 39386952 & Deleção & 1 & 139,9 & 76 & ADAM5P, ADAM3A \\
\hline 246 & 15 & 11 & q11 & 55374018 & 55452996 & Deleção & 1 & 79,0 & 100 & OR4P4, OR4S2, OR4C6 \\
\hline 247 & 15 & 12 & p11.23 & 27646150 & 27659531 & Deleção & 1 & 13,4 & 28 & C12orf70 \\
\hline 248 & 15 & 14 & q32.2 & 99181303 & 99197359 & Deleção & 1 & 16,1 & 28 & C14orf177 \\
\hline 249 & 15 & $x$ & p22.33 & 1378501 & 1506308 & Duplicação & 4 & 127,8 & 78 & CSF2RA, IL3RA, SLC25A6 \\
\hline 250 & 15 & $x$ & q24 & 119137289 & 119153785 & Deleção & 1 & 16,5 & 34 & - \\
\hline 251 & 15 & $x$ & $\mathrm{q} 27.1$ & 139804197 & 139806255 & Deleção & 1 & 2,1 & 36 & - \\
\hline 253 & 16 & 2 & q34 & 213173378 & 213192832 & Deleção & 1 & 19,5 & 72 & ERBB4 \\
\hline 254 & 16 & 3 & p14.1 & 65517399 & 65595008 & Duplicação & 3 & 77,6 & 128 & MAGI1 \\
\hline 255 & 16 & 4 & $\mathrm{p} 12$ & 46103404 & 46124667 & Deleção & 1 & 21,3 & 28 & GABRG1 \\
\hline 256 & 16 & 5 & $\mathrm{q} 21.2$ & 104433580 & 104498041 & Deleção & 1 & 64,5 & 60 & RAB9BP1 \\
\hline 257 & 16 & 8 & $\mathrm{p} 23.2$ & 6015415 & 6045397 & Deleção & 1 & 30,0 & 30 & - \\
\hline 258 & 16 & 8 & p11.22 & 39225874 & 39386952 & Deleção & 1 & 161,1 & 84 & ADAM5P, ADAM3A \\
\hline 259 & 16 & 8 & q22.3 & 102388024 & 102408295 & Deleção & 1 & 20,3 & 48 & - \\
\hline 260 & 16 & 8 & q24.23 & 137689301 & 137862435 & Deleção & 1 & 173,1 & 112 & - \\
\hline 261 & 16 & 11 & p15.4 & 5783909 & 5809230 & Deleção & 1 & 25,3 & 48 & OR52N5, OR52N1 \\
\hline
\end{tabular}




\begin{tabular}{|c|c|c|c|c|c|c|c|c|c|c|}
\hline 262 & 16 & 13 & q21.1 & 57758376 & 57778367 & Deleção & 1 & 20,0 & 32 & - \\
\hline 263 & 16 & 14 & q32.33 & 106246288 & 106761968 & Duplicação & 3 & 515,7 & 202 & $\begin{array}{l}\text { KIAA0125, ADAM6, } \\
\text { NCRNA00226 }\end{array}$ \\
\hline 264 & 16 & 22 & $\mathrm{q} 11.22$ & 23124497 & 23183112 & Duplicação & 3 & 58,6 & 56 & MIR650 \\
\hline 265 & 16 & $x$ & p22.33 & 356232 & 401509 & Duplicação & 3 & 45,3 & 60 & - \\
\hline 266 & 16 & $x$ & p22.33 & 538788 & 570992 & Duplicação & 3 & 32,2 & 110 & - \\
\hline 267 & 16 & $x$ & p22.33 & 817312 & 837452 & Deleção & 1 & 20,1 & 56 & - \\
\hline 268 & 16 & $x$ & p22.33 & 1793055 & 1812233 & Deleção & 1 & 19,2 & 36 & - \\
\hline 269 & 16 & $x$ & p22.33 & 2295258 & 2302145 & Deleção & 1 & 6,9 & 32 & DHRSX \\
\hline 270 & 16 & $x$ & p22.33 & 2370149 & 2382966 & Deleção & 1 & 12,8 & 64 & DHRSX \\
\hline 271 & 16 & $x$ & $\mathrm{p} 22.31$ & 6621971 & 6634382 & Duplicação & 3 & 12,4 & 68 & - \\
\hline 272 & 16 & $x$ & p21.3 & 29114199 & 29117748 & Deleção & 1 & 3,5 & 27 & IL1RAPL1 \\
\hline 273 & 16 & $x$ & p11.23 & 49713119 & 49721454 & Deleção & 1 & 8,3 & 36 & CLCN5 \\
\hline 274 & 16 & $x$ & p11.22 & 53475174 & 53479503 & Deleção & 1 & 4,3 & 34 & - \\
\hline 275 & 16 & $x$ & q21.1 & 77904920 & 77968206 & Deleção & 1 & 63,3 & 56 & ZCCHC5 \\
\hline 276 & 16 & $x$ & q21.32 & 92302268 & 92387213 & Deleção & 1 & 84,9 & 38 & - \\
\hline 277 & 16 & $x$ & q23 & 115133388 & 115163259 & Deleção & 1 & 29,9 & 76 & - \\
\hline 278 & 16 & $x$ & q23 & 115751421 & 115754656 & Deleção & 1 & 3,2 & 36 & - \\
\hline 279 & 16 & $x$ & q26.3 & 133643248 & 133654688 & Deleção & 1 & 11,4 & 26 & - \\
\hline 280 & 16 & $x$ & q26.3 & 136638059 & 136667227 & Duplicação & 4 & 29,2 & 84 & $\mathrm{ZIC3}$ \\
\hline 281 & 16 & $x$ & $q 27.1$ & 139493361 & 139497990 & Duplicação & 4 & 4,6 & 51 & - \\
\hline
\end{tabular}




\begin{tabular}{|c|c|c|c|c|c|c|c|c|c|c|}
\hline 282 & 16 & $x$ & q28 & 154918771 & 154946935 & Deleção & 0 & 28,2 & 33 & - \\
\hline 283 & 17 & 3 & $\mathrm{p} 11.1$ & 89407024 & 89416364 & Deleção & 1 & 9,3 & 29 & EPHA3 \\
\hline 285 & 17 & 6 & $\mathrm{q} 12$ & 67009022 & 67051189 & Deleção & 1 & 42,2 & 30 & - \\
\hline 286 & 17 & 8 & p11.22 & 39247097 & 39386952 & Deleção & 1 & 139,9 & 76 & ADAM5P, ADAM3A \\
\hline 287 & 17 & 11 & p15.1 & 18941196 & 18961268 & Deleção & 1 & 20,1 & 48 & MRGPRX1 \\
\hline 288 & 17 & 13 & q31.1 & 84106471 & 84155572 & Deleção & 1 & 49,1 & 49 & - \\
\hline 289 & 17 & 14 & q21.1 & 41608615 & 41695300 & Deleção & 1 & 86,7 & 28 & - \\
\hline 290 & 17 & 14 & q32.33 & 106273119 & 106328303 & Duplicação & 3 & 55,2 & 68 & - \\
\hline 291 & 17 & 14 & q32.33 & 106329183 & 106710077 & Duplicação & 3 & 380,9 & 58 & KIAA0125, ADAM6 \\
\hline 293 & 17 & 20 & p12.1 & 15107160 & 15130400 & Deleção & 0 & 23,2 & 27 & MACROD2 \\
\hline 294 & 17 & $x$ & p11.22 & 52833688 & 52904643 & Duplicação & 3 & 71,0 & 80 & XAGE5, XAGE3 \\
\hline 295 & 17 & $x$ & $\mathrm{q} 26.3$ & 134928992 & 134966528 & Duplicação & 4 & 37,5 & 104 & СТ45A4, СТ45A5, СТ45A6 \\
\hline 296 & 18 & 1 & q32.2 & 210604732 & 210612839 & Deleção & 1 & 8,1 & 32 & HHAT \\
\hline 297 & 18 & 3 & p21.31 & 46801991 & 46849576 & Deleção & 1 & 47,6 & 45 & - \\
\hline 298 & 18 & 4 & p15.1 & 34773540 & 34831805 & Deleção & 1 & 58,3 & 25 & - \\
\hline 299 & 18 & 4 & q24 & 104199891 & 104251349 & Deleção & 1 & 51,5 & 37 & - \\
\hline 300 & 18 & 6 & $\mathrm{q} 12$ & 67004972 & 67048629 & Deleção & 1 & 43,7 & 30 & - \\
\hline
\end{tabular}




\begin{tabular}{|c|c|c|c|c|c|c|c|c|c|c|}
\hline 301 & 18 & 8 & $\mathrm{p} 11.22$ & 39247097 & 39386952 & Deleção & 1 & 139,9 & 76 & ADAM5P, ADAM3A \\
\hline 302 & 18 & 8 & q24.22 & 134145522 & 134183087 & Deleção & 1 & 37,6 & 40 & TG \\
\hline 303 & 18 & 12 & $\mathrm{p} 13.2$ & 11217136 & 11256728 & Deleção & 1 & 39,6 & 42 & PRR4, PRH1, TAS2R43 \\
\hline 304 & 18 & 14 & q23.3 & 67193022 & 67217571 & Deleção & 1 & 24,5 & 41 & GPHN \\
\hline 305 & 18 & 14 & q32.33 & 106329183 & 106746713 & Duplicação & 3 & 417,5 & 80 & $\begin{array}{l}\text { KIAA0125, ADAM6, } \\
\text { NCRNA00226 }\end{array}$ \\
\hline 306 & 18 & 17 & $\mathrm{q} 21.2$ & 39511103 & 39522403 & Deleção & 1 & 11,3 & 32 & KRT33B \\
\hline 307 & 18 & 19 & q13.31 & 44896886 & 44938778 & Deleção & 1 & 41,9 & 60 & ZNF285, ZNF229 \\
\hline 308 & 18 & 19 & $\mathrm{q} 13.42$ & 54718076 & 54752217 & Deleção & 1 & 34,1 & 34 & LILRB3, LILRA6 \\
\hline 309 & 18 & $x$ & p22.33 & 986336 & 995026 & Deleção & 1 & 8,7 & 28 & - \\
\hline 310 & 18 & $\mathrm{x}$ & $\mathrm{q} 11.2$ & 64419018 & 64664114 & Deleção & 1 & 245,1 & 86 & - \\
\hline 311 & 19 & 1 & p36.33 & 1621773 & 1672591 & Deleção & 0 & 50,8 & 38 & $\begin{array}{l}\text { CDK11B, SLC35E2B, } \\
\text { MMP23A, CDK11A, } \\
\text { SLC35E2 }\end{array}$ \\
\hline 312 & 19 & 1 & q44 & 248755341 & 248795277 & Deleção & 1 & 39,9 & 48 & OR2T10, OR2T11 \\
\hline 313 & 19 & 2 & p22.3 & 34219274 & 34313413 & Deleção & 1 & 94,1 & 58 & - \\
\hline 314 & 19 & 2 & q33.1 & 203295762 & 203313469 & Deleção & 1 & 17,7 & 92 & BMPR2 \\
\hline 315 & 19 & 4 & $q 13.2$ & 69435966 & 69540420 & Deleção & 1 & 104,5 & 46 & UGT2B15 \\
\hline 316 & 19 & 5 & q23.1 & 115586765 & 115625244 & Deleção & 1 & 38,5 & 56 & COMMD10 \\
\hline 317 & 19 & 6 & p25.3 & 254282 & 294826 & Deleção & 1 & 40,5 & 87 & DUSP22 \\
\hline 318 & 19 & 6 & q12 & 67004972 & 67051189 & Deleção & 1 & 46,2 & 32 & - \\
\hline 319 & 19 & 7 & p14.1 & 38319295 & 38349129 & Deleção & 1 & 29,8 & 64 & - \\
\hline
\end{tabular}




\begin{tabular}{|c|c|c|c|c|c|c|c|c|c|c|}
\hline 320 & 19 & 7 & q34 & 142453878 & 142485841 & Deleção & 1 & 32,0 & 52 & PRSS1, TRY6, PRSS2 \\
\hline 321 & 19 & 11 & q11 & 55374175 & 55452996 & Deleção & 1 & 78,8 & 96 & OR4P4, OR4S2, OR4C6 \\
\hline 322 & 19 & 12 & q23.1 & 99795454 & 99798721 & Deleção & 1 & 3,3 & 30 & ANKS1B \\
\hline 323 & 19 & 13 & q21.1 & 57750940 & 57776590 & Deleção & 0 & 25,7 & 36 & - \\
\hline 324 & 19 & 14 & q11.2 & 22578241 & 22937656 & Deleção & 1 & 359,4 & 580 & - \\
\hline 325 & 19 & 14 & q32.33 & 106329183 & 107179594 & Duplicação & 3 & 850,4 & 356 & $\begin{array}{l}\text { KIAA0125, ADAM6, } \\
\text { NCRNA00226, } \\
\text { NCRNA00221 }\end{array}$ \\
\hline 326 & 19 & 19 & $\mathrm{q} 13.2$ & 41352625 & 41385370 & Deleção & 1 & 32,7 & 46 & CYP2A6, CYP2A7 \\
\hline 327 & 19 & $\mathrm{x}$ & p22.33 & 2295258 & 2302145 & Deleção & 1 & 6,9 & 32 & DHRSX \\
\hline 328 & 19 & $x$ & p21.1 & 32742109 & 32743344 & Deleção & 1 & 1,2 & 32 & DMD \\
\hline 330 & 19 & $x$ & q25 & 120973848 & 121005062 & Deleção & 1 & 31,2 & 26 & - \\
\hline 331 & 19 & $x$ & q26.3 & 133642080 & 133654661 & Deleção & 1 & 12,6 & 29 & - \\
\hline 332 & 19 & $\mathrm{x}$ & q26.3 & 134675739 & 134947464 & Duplicação & 3 & 271,7 & 899 & $\begin{array}{l}\text { DDX26B, CT45A1, } \\
\text { CT45A2, CT45A4, } \\
\text { CT45A3, CT45A5 }\end{array}$ \\
\hline 333 & 19 & $x$ & q28 & 147317018 & 147325589 & Deleção & 1 & 8,6 & 44 & - \\
\hline 334 & 20 & 1 & q44 & 248753332 & 248795277 & Deleção & 1 & 41,9 & 56 & OR2T10, OR2T11 \\
\hline 335 & 20 & 2 & $\mathrm{p} 22.2$ & 36932842 & 36964864 & Deleção & 1 & 32,0 & 45 & VIT \\
\hline 336 & 20 & 3 & p11.1 & 89407024 & 89416364 & Deleção & 1 & 9,3 & 29 & EPHA3 \\
\hline 337 & 20 & 6 & p25.3 & 254253 & 294826 & Deleção & 1 & 40,6 & 88 & DUSP22 \\
\hline 338 & 20 & 6 & p21.33 & 31256082 & 31265971 & Deleção & 1 & 9,9 & 36 & - \\
\hline
\end{tabular}




\begin{tabular}{|c|c|c|c|c|c|c|c|c|c|c|}
\hline 339 & 20 & 8 & $\mathrm{p} 11.22$ & 39247097 & 39386952 & Deleção & 1 & 139,9 & 76 & ADAM5P, ADAM3A \\
\hline 340 & 20 & 11 & p15.4 & 5783909 & 5809230 & Deleção & 0 & 25,3 & 48 & OR52N5, OR52N1 \\
\hline 341 & 20 & 12 & $\mathrm{p} 13.2$ & 11216816 & 11251705 & Deleção & 1 & 34,9 & 40 & PRR4, PRH1, TAS2R43 \\
\hline 342 & 20 & 12 & q23.1 & 99791757 & 99798721 & Deleção & 1 & 7,0 & 33 & ANKS1B \\
\hline 343 & 20 & 15 & $\mathrm{q} 11.2$ & 24457662 & 24478240 & Deleção & 1 & 20,6 & 34 & - \\
\hline 344 & 20 & $x$ & $\mathrm{q} 21.31$ & 88976798 & 89028374 & Deleção & 1 & 51,6 & 27 & - \\
\hline 345 & 20 & $x$ & q23 & 115576235 & 115589080 & Deleção & 1 & 12,8 & 52 & SLC6A14 \\
\hline 346 & 20 & $\mathrm{x}$ & q26.3 & 134928992 & 134966528 & Duplicação & 4 & 37,5 & 104 & CT45A4, CT45A5, СТ45A6 \\
\hline 347 & 21 & 1 & q21.1 & 145014996 & 145069305 & Duplicação & 3 & 54,3 & 92 & PDE4DIP \\
\hline 348 & 21 & 1 & q21.3 & 152761910 & 152773905 & Deleção & 1 & 12,0 & 28 & LCE1D \\
\hline 350 & 21 & 3 & q13.33 & 120466531 & 120481952 & Deleção & 1 & 15,4 & 28 & GTF2E1 \\
\hline 351 & 21 & 5 & q35.3 & 180378874 & 180430789 & Deleção & 1 & 51,9 & 34 & BTNL3 \\
\hline 352 & 21 & 7 & q34 & 142820842 & 142891708 & Deleção & 1 & 70,9 & 83 & PIP, TAS2R39 \\
\hline 353 & 21 & 8 & p11.22 & 39247097 & 39386952 & Deleção & 1 & 139,9 & 76 & ADAM5P, ADAM3A \\
\hline 354 & 21 & 9 & q21.12 & 73423869 & 73446819 & Deleção & 1 & 23,0 & 28 & TRPM3, MIR204 \\
\hline 355 & 21 & 9 & q32 & 115392790 & 115591155 & Duplicação & 3 & 198,4 & 187 & $\begin{array}{l}\text { KIAA1958, C9orf80, } \\
\text { SNX30 }\end{array}$ \\
\hline 356 & 21 & 14 & q11.2 & 22390504 & 22408688 & Deleção & 1 & 18,2 & 27 & - \\
\hline 357 & 21 & 14 & q23.3 & 67111441 & 67148873 & Duplicação & 3 & 37,4 & 62 & GPHN \\
\hline 358 & 21 & 14 & q32.33 & 106328973 & 106728149 & Duplicação & 4 & 399,2 & 74 & KIAA0125, ADAM6 \\
\hline
\end{tabular}




\begin{tabular}{|c|c|c|c|c|c|c|c|c|c|c|}
\hline 359 & 21 & 16 & $q 12.2$ & 55796375 & 55816692 & Deleção & 1 & 20,3 & 28 & CES1P1 \\
\hline 360 & 21 & 20 & $\mathrm{q} 13.2$ & 52652344 & 52658060 & Deleção & 1 & 5,7 & 26 & BCAS1 \\
\hline 361 & 21 & 22 & $\mathrm{q} 12.3$ & 34188089 & 34227501 & Deleção & 1 & 39,4 & 160 & LARGE \\
\hline 362 & 21 & $x$ & p22.31 & 8189571 & 8189966 & Deleção & 1 & 0,4 & 26 & - \\
\hline 363 & 21 & $x$ & q21.31 & 89752139 & 89878515 & Deleção & 1 & 126,4 & 44 & - \\
\hline 364 & 21 & $x$ & q21.33 & 94374390 & 94469750 & Deleção & 1 & 95,4 & 57 & - \\
\hline 365 & 21 & $x$ & q26.3 & 134928992 & 134966528 & Duplicação & 4 & 37,5 & 104 & CT45A4, СТ45A5, СТ45A6 \\
\hline 366 & 21 & $x$ & q26.3 & 136495210 & 136495793 & Deleção & 1 & 0,6 & 25 & - \\
\hline 367 & 21 & $x$ & q28 & 147317018 & 147325589 & Deleção & 1 & 8,6 & 44 & - \\
\hline 368 & 22 & 3 & p21.31 & 46793363 & 46872554 & Deleção & 1 & 79,2 & 55 & PRSS42 \\
\hline 370 & 22 & 4 & q13.2 & 69435888 & 69551731 & Deleção & 1 & 115,8 & 60 & UGT2B15 \\
\hline 371 & 22 & 4 & q24 & 104199891 & 104250294 & Deleção & 1 & 50,4 & 32 & - \\
\hline 372 & 22 & 5 & q35.3 & 180378753 & 180430789 & Deleção & 1 & 52,0 & 36 & BTNL3 \\
\hline 373 & 22 & 7 & p22.3 & 154720 & 158615 & Deleção & 1 & 3,9 & 28 & - \\
\hline 374 & 22 & 8 & p11.22 & 39247097 & 39386952 & Deleção & 1 & 139,9 & 76 & ADAM5P, ADAM3A \\
\hline 375 & 22 & 10 & $\mathrm{q} 26.3$ & 135357401 & 135427143 & Duplicação & 3 & 69,7 & 81 & SYCE1, SPRNP1 \\
\hline 376 & 22 & 11 & q11 & 55374018 & 55442305 & Deleção & 1 & 68,3 & 80 & OR4P4, OR4S2, OR4C6 \\
\hline 377 & 22 & 14 & q32.33 & 106329183 & 106896439 & Duplicação & 3 & 567,3 & 128 & $\begin{array}{l}\text { KIAA0125, ADAM6, } \\
\text { NCRNA00226 }\end{array}$ \\
\hline 378 & 22 & 18 & $\mathrm{q} 12.2$ & 36426123 & 36494542 & Deleção & 1 & 68,4 & 56 & - \\
\hline
\end{tabular}




\begin{tabular}{|c|c|c|c|c|c|c|c|c|c|c|}
\hline 379 & 22 & 21 & $\mathrm{q} 21.2$ & 24379491 & 24450835 & Deleção & 1 & 71,3 & 52 & - \\
\hline 380 & 22 & $x$ & p21.3 & 29160657 & 29174711 & Deleção & 0 & 14,1 & 54 & IL1RAPL1 \\
\hline 382 & 22 & $x$ & q26.2 & 130649648 & 130980665 & Duplicação & 3 & 331,0 & 248 & OR13H1, LOC286467 \\
\hline 383 & 22 & $x$ & q28 & 147317018 & 147325589 & Deleção & 1 & 8,6 & 44 & - \\
\hline 384 & 22 & $x$ & q28 & 148884728 & 148958011 & Duplicação & 3 & 73,3 & 88 & - \\
\hline 385 & 23 & 1 & p12 & 120104042 & 120140010 & Deleção & 1 & 36,0 & 36 & HSD3BP4 \\
\hline 386 & 23 & 1 & q21.1 & 144086896 & 144567360 & Duplicação & 3 & 480,5 & 65 & $\begin{array}{l}\text { SRGAP2P2, LOC728855, } \\
\text { LOC728875, PPIAL4B, } \\
\text { PPIAL4C, PPIAL4A }\end{array}$ \\
\hline 387 & 23 & 1 & q44 & 248753332 & 248795277 & Deleção & 1 & 41,9 & 56 & OR2T10, OR2T11 \\
\hline 389 & 23 & 3 & $\mathrm{q} 21.2$ & 125708696 & 125721738 & Deleção & 1 & 13,0 & 32 & - \\
\hline 390 & 23 & 3 & q28 & 189360742 & 189371964 & Deleção & 1 & 11,2 & 35 & TP63 \\
\hline 391 & 23 & 5 & q12.1 & 61420500 & 61471447 & Deleção & 1 & 50,9 & 36 & - \\
\hline 392 & 23 & 5 & q35.3 & 180378753 & 180418090 & Deleção & 1 & 39,3 & 34 & BTNL3 \\
\hline 393 & 23 & 9 & p24.1 & 6714317 & 6795052 & Duplicação & 3 & 80,7 & 64 & KDM4C \\
\hline 394 & 23 & 11 & q11 & 54965374 & 55039246 & Deleção & 1 & 73,9 & 56 & TRIM48 \\
\hline 395 & 23 & 12 & p13.2 & 11217136 & 11251861 & Deleção & 1 & 34,7 & 39 & PRR4, PRH1, TAS2R43 \\
\hline 396 & 23 & 12 & q23.1 & 99791778 & 99798721 & Deleção & 1 & 6,9 & 32 & ANKS1B \\
\hline 397 & 23 & 14 & q32.33 & 106246288 & 106519050 & Duplicação & 3 & 272,8 & 138 & KIAA0125, ADAM6 \\
\hline
\end{tabular}


Adendo $127 / 127$

\begin{tabular}{|c|c|c|c|c|c|c|c|c|c|c|}
\hline 398 & 23 & 19 & $\mathrm{q} 13.2$ & 41352688 & 41392187 & Deleção & 1 & 39,5 & 47 & CYP2A6, CYP2A7 \\
\hline 399 & 23 & 22 & q13.31 & 46695304 & 46706364 & Deleção & 1 & 11,1 & 28 & GTSE1 \\
\hline 401 & 23 & $x$ & p21.3 & 29111923 & 29117749 & Deleção & 0 & 5,8 & 37 & IL1RAPL1 \\
\hline 402 & 23 & $x$ & $\mathrm{p} 11.23$ & 47865294 & 48001375 & Duplicação & 3 & 136,1 & 100 & $\begin{array}{l}\text { SPACA5, SPACA5B } \\
\text { ZNF630, SSX6 }\end{array}$ \\
\hline 403 & 23 & $\mathrm{x}$ & q26.1 & 129375388 & 129383116 & Deleção & 1 & 7,7 & 29 & ZNF280C \\
\hline 404 & 23 & $x$ & q26.3 & 134947463 & 134962480 & Deleção & 1 & 15,0 & 30 & СТ45А5 \\
\hline 405 & 23 & $\mathrm{x}$ & q26.3 & 136943142 & 136952177 & Duplicação & 3 & 90,4 & 88 & - \\
\hline 406 & 23 & $\mathrm{x}$ & q28 & 154918771 & 154952242 & Deleção & 1 & 33,5 & 36 & \\
\hline
\end{tabular}

